\title{
Effects of air humidity on development, physiology and distribution of temperate woodland herbs and tree saplings
}

\author{
Dissertation \\ zur Erlangung des Doktorgrades \\ der Mathematisch-Naturwissenschaftlichen Fakultäten \\ der Georg-August-Universität zu Göttingen
}

vorgelegt von

Jasmin Lendzion

aus Wuppertal 
D 7

Referent: Prof. Dr. Christoph Leuschner

Korreferent: PD Dr. Michael Kessler

Tag der mündlichen Prüfung: 31.10.2007 


\section{Table of contents}

Summary

\section{Zusammenfassung}

\section{Chapter 1}

General introduction

\section{Chapter 2}

Material and methods

\section{Chapter 3}

Temperate forest herbs are adapted to high air humidity- evidence from climate chamber and humidity manipulation experiments in the field

\section{Chapter 4}

Growth of European beech (Fagus sylvatica L.) saplings is limited by elevated atmospheric vapor pressure deficits

\section{Chapter 5}

Air humidity, soil moisture and soil chemical factors as determinants of the herb layer composition in beech forests

Chapter 6

Synopsis

References

Danksagung 


\section{Summary}

According to climate change the risk of summer droughts will rise in large parts of Central Europe because of decreased or missing precipitation during summer. Decreased precipitation and increased temperature could reduce air humidity, which might affect terrestrial ecosystems that are adapted to humid conditions such as the forest floor environment.

The present study investigated long-term effects of contrasting air humidity levels on growth, physiology and distribution of woodland herbs and tree saplings. Major aims were to examine (i) whether species of the forest floor vegetation require high air humidity for optimal growth, and (ii) if reductions of air humidity have negative consequences for the species of this environment.

The effects of air humidity on growth and physiology of two temperate woodland herb species (Mercurialis perennis L. and Stachys sylvatica L.) and saplings of European beech (Fagus sylvatica L.) were investigated in an experimental study. In climate chamber experiments, the species were grown in three different air humidity treatments (40\%, $60 \%$ and $85 \%$ relative humidity) and in nutrient solution cultures with unlimited water supply. For the simulation of a drier climate on the forest floor, an innovative field experiment with open-top chambers was developed. The open-top chambers were established in a beech forest in southern Lower Saxony, and air humidity was reduced by about $15 \%$ while other growth conditions were maintained constant. To investigate the importance of air humidity for the forest floor vegetation under complete natural conditions, an observational field study was conducted in beech forests of southern Lower Saxony, and the importance of air humidity on the distribution of woodland herbs was analyzed through a correlative approach and compared to that of other abiotic factors.

The results of the experimental investigations and the observational field study showed a strong influence of air humidity on growth, physiology, and distribution of woodland herbs and beech saplings. In the climate chamber experiment and the open-top chamber experiment, all three investigated species were negatively affected when they were grown under reduced air humidity. An air humidity reduction of $45 \%$ in the climate chamber experiment resulted in a dry matter reduction of $40 \%$ in the two woodland herb species and of $68 \%$ in the beech saplings. In the open-top chamber experiment, an air humidity reduction of $15 \%$ on the forest floor resulted in a biomass decrease of $25 \%$ to $30 \%$. In both experiments and in all species the reduction in biomass in the dry 
air treatments was closely associated with a reduction in leaf area. The decline in leaf area was either due to a reduced number of leaves, or a decreased average leaf size, or both.

The observed leaf growth reduction under atmospheric drought was probably a consequence of higher transpirative water loss and lowered leaf turgor in the dry air treatments, and not caused by limited carbon assimilation. In all three species, the transpiration rate increased significantly when air humidity was reduced, and the higher transpirative water loss was linked to decreased leaf water content, lowered leaf water potentials, and reduced leaf turgor. In contrast, although average leaf conductance was significantly lowered in the dry air treatments, light-saturated net photosynthesis rate was not reduced.

In the observational field study, air humidity, soil moisture and the concentration of exchangeable calcium and potassium in the soil were identified as the most important abiotic site factors influencing the abundance of woodland herb species and total herb cover. Air humidity varied substantially across different micro-sites and influenced species abundance independently of soil moisture. For several species, air humidity was found to be the most important key environmental factor, which is in accordance with the results of the experimental investigation.

These results show that air humidity is an important and soil moisture independent growth and site factor for the forest floor vegetation. Low atmospheric moisture can produce drought stress in woodland herbs and tree saplings, even though soil moisture is not limiting. Woodland herbs and tree saplings require for optimal growth and development sufficiently high air humidity. A decrease of air humidity as a result of gap formation, clear-cutting of forests, or in a drier climate with longer and more intense summer droughts might strongly threaten species of the forest floor environment. 


\section{Zusammenfassung}

Die im Zuge des Klimawandels für weite Teile Mitteleuropas prognostizierten lokal verringerten Sommerniederschläge und längeren Trockenperioden werden vermutlich zu einer Abnahme der relativen Luftfeuchte führen. Eine Abnahme der relativen Luftfeuchte könnte insbesondere Ökosysteme beeinflussen, die an hohe Luftfeuchtebedingungen angepasst sind, wie z.B. die Waldbodenvegetation.

In der vorliegenden Studie wurden die Langzeiteffekte unterschiedlicher Luftfeuchtebedingungen auf das Wachstum, die Physiologie und die Verbreitung von Krautschichtpflanzen des Waldbodens und der Baumverjüngung untersucht. Folgende Hypothesen wurden getestet: (1) Waldbodenpflanzen benötigen für ein optimales Wachstum hohe Luftfeuchte und (2) eine Verringerung der Luftfeuchte hat negative Folgen für die Waldbodenvegetation.

In einer experimentellen Studie wurde der Einfluss der Luftfeuchte auf das pflanzliche Wachstum und die Physiologie an zwei typischen Krautschichtarten aus Kalkbuchenwäldern (Stachys sylvatica L. und Mercurialis perennis L.), sowie an Jungpflanzen der Rotbuche (Fagus sylvatica L.) untersucht. In KlimakammerExperimenten wurden die Pflanzen unter drei unterschiedlichen Luftfeuchtebedingungen $(40 \%, 60 \%$ und $85 \%$ relativer Luftfeuchte) bei uneingeschränkter Wasserversorgung angezogen. Um die Luftfeuchte im natürlichen Bestand zu reduzieren wurde eine innovative Anlage entwickelt. Diese Anlage wurde in einem Buchenwald in Südniedersachsen aufgebaut und ermöglichte eine Absenkung der relativen Luftfeuchte am Waldboden um 15\%, während andere Umweltparameter unverändert blieben. Um auch den Einfluss der Luftfeuchte auf die Waldbodenvegetation unter rein natürlichen Bedingungen zu untersuchen, wurde eine Freilandstudie in südniedersächsischen Buchenwäldern durchgeführt. In einem korrelativen Ansatz wurde die relative Bedeutung der Einflussvariable Luftfeuchte auf das Vorkommen von Waldboden-Krautschichtpflanzen untersucht und mit dem Einfluss anderer abiotischer Umweltparameter verglichen.

Nicht nur in den experimentellen Versuchen sondern auch in der Freilandstudie zeigte sich, dass der Faktor Luftfeuchte einen großen Einfluss auf das Wachstum, die Physiologie und die Verbreitung von Krautschichtpflanzen des Waldbodens und von Buchenjungpflanzen hatte. Sowohl in den Klimakammer-Experimenten als auch in den Freilandexperimenten mit manipulierten Luftgemischen zeigte sich, dass alle drei untersuchten Arten negativ auf eine Abnahme der Luftfeuchte reagierten. Eine Absenkung der Luftfeuchte um $45 \%$ in den Klimakammern führte zu einer reduzierten 
Biomasseproduktion von $40 \%$ in beiden krautigen Arten und sogar zu $68 \%$ in den Buchenjungpflanzen. In vergleichbarer Weise reduzierte experimentell um 15\% abgetrocknete Luft am Waldboden das Wachstum der drei untersuchten Arten um 25\% bis $30 \%$. Bei allen untersuchten Arten war die Abnahme der Biomasseproduktion bei Lufttrockenheit stark korreliert mit einer Abnahme der Gesamtblattfläche. Die Ursache für die Verringerung der Gesamtblattfläche bei niedriger Luftfeuchte war entweder eine verringerte Einzelblattfläche oder eine Verringerung der Blattzahl oder beides.

Die beobachtete Reduktion des Blattwachstums bei niedriger Luftfeuchte wurde vermutlich durch einen höheren transpirativen Wasserverlust und einem dadurch verringerten Turgor ausgelöst und nicht durch eine Limitierung der Kohlenstoffaufnahme. Bei allen drei untersuchten Arten zeigte sich eine signifikante Zunahme der Transpirationsrate bei abnehmender Luftfeuchte. Diese war korreliert mit einer Abnahme der Blattwassergehalte, des Blattwasserpotentials und mit einem reduzierten Turgor. Obwohl die Blattleitfähigkeit unter niedriger Luftfeuchte eingeschränkt war, zeigte sich keine Reduzierung der Netto-Photosyntheserate.

Die Freilandstudie zeigte, dass Luftfeuchte, Bodenfeuchte und die Konzentration an austauschbarem Kalzium und Kalium im Boden die wichtigsten Umweltfaktoren für die Waldbodenvegetation darstellten. Die gemessene Luftfeuchte unterschied sich stark zwischen verschiedenen Mikro-Standorten und ihr Einfluss auf die Waldbodenvegetation war unabhängig von der Bodenfeuchte. Für zahlreiche Waldbodenpflanzen war die Luftfeuchte der entscheidende Umweltfaktor. Dieses Ergebnis bestätigt die Ergebnisse der experimentellen Untersuchungsansätze.

Die vorliegende Untersuchung zeigt, dass Luftfeuchte einen wichtigen, bodenfeuchteunabhängigen Faktor für die Waldbodenvegetation darstellt. Niedrige Luftfeuchte kann selbst bei optimaler Bodenfeuchte zu Trockenstress in Pflanzen führen. Sowohl Krautschichtpflanzen als auch die Baumverjüngung benötigen für ein optimales Wachstum und eine optimale Entwicklung eine ausreichend hohe Luftfeuchte. Eine Abnahme der Luftfeuchte im Zuge des Klimawandels, bei der Bildung von Bestandeslücken oder in Aufforstungen könnte daher zahlreiche Arten der Waldbodenvegetation erheblich gefährden. 


\title{
Chapter 1
}

\author{
General Introduction
}

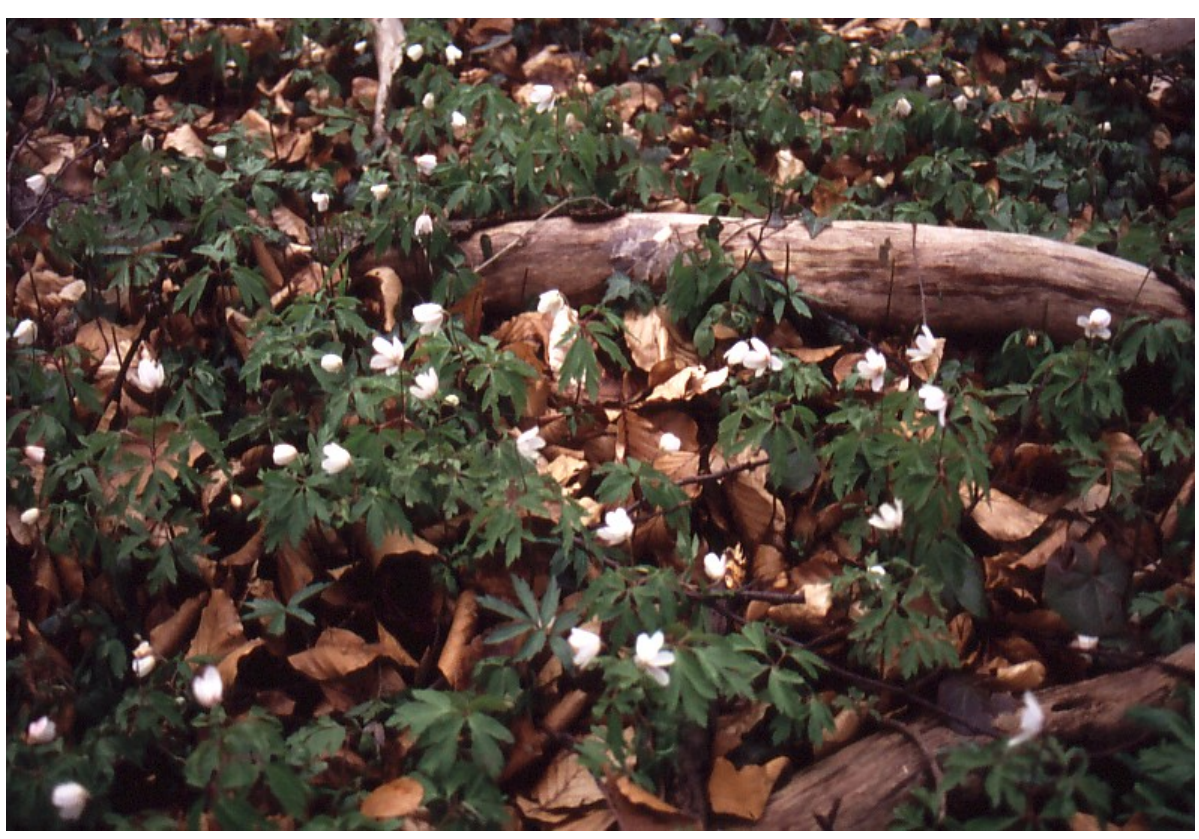




\section{Aspects of global climate change}

The global climate has changed many times during the earth's history, with events ranging from ice ages to long periods of warmth. Historically, natural factors have affected the global climate, whereas the climate changes actually observed have been suggested to be the consequence of human activities (IPCC 2001, 2007).

\section{Carbon dioxide, temperature and precipitation}

For over the past 200 years, the burning of fossil fuels, deforestation, land use change and livestock breeding have caused increasing emissions of greenhouse gases, which are assumed to be the primary cause of global warming (SCHÖNWIESE et al. 2003). Carbon dioxide is considered to be the most important anthropogenic greenhouse gas and its global atmospheric concentration has increased from a pre-industrial value of 280 ppm to 379 ppm in 2005 (IPCC 2007). The atmospheric concentration of $\mathrm{CO}_{2}$ in 2005 exceeded by far the natural range over the last 650,000 years (180 to $300 \mathrm{ppm}$ ). Levels of $\mathrm{CO}_{2}$ are expected to continue rising, and current estimates predict a concentration of 525 to 950 ppm by the end of the $21^{\text {st }}$ century (IPCC 2001).

The latest assessment report of the IPCC (2007) predicts that the temperature will increase by about $0.2^{\circ} \mathrm{C}$ per decade, which is analogous to a temperature increase of about $1.8^{\circ} \mathrm{C}$ to $4{ }^{\circ} \mathrm{C}$ until the end of this century. The world-wide average temperature has already increased by about $0.7{ }^{\circ} \mathrm{C}$ during the last 100 years. In Germany, temperatures have increased by $0.9{ }^{\circ} \mathrm{C}$ in the last 100 years, which is even more than the global trend (SCHÖNWIESE et al. 2003). Widespread increases in extreme temperatures have been observed over the last 50 years. Hot days, hot nights, and heat waves have become more frequent, while cold days, cold nights, and frost have become less frequent (IPCC 2007). Summer heat waves as in 2003 have been predicted to become more frequent in central, eastern, and southern Europe (EEA 2004, ROWELL \& JONES 2006).

Climate models predict further changes in global and regional precipitation (IPCC 2007). For Europe, winter rainfall is predicted to increase, while summer rainfall is predicted to decrease. The world-wide precipitation amount and the atmospheric water vapor concentration have increased up until the present, but there is a shift in regional and seasonal precipitation patterns. In Europe, precipitation has decreased in the eastern Mediterranean, but has increased in southern Scandinavia. In Germany, precipitation has increased during winter, but has decreased slightly in summer. The decreases in summer rainfall are somewhat more pronounced in eastern Germany 
(SCHÖNWIESE et al. 2003). Besides changes in precipitation, the risk of summer droughts has been predicted to increase in large parts of Europe, and for continental Europe, summers are expected to be generally drier (MANABE \& WETHERALD 1987, WetHeRALD \& MANABE 1995, GREGORY et al. 1997, IPCC 2001).

Water vapor and relative humidity

Water vapor, the most important natural greenhouse gas and a key driver of many atmospheric processes, is fundamental to the climate system. As the air warms, due to the expected temperature increase, evaporation increases and the concentration of atmospheric water vapor will increase. Therefore, climate-forecasting models have predicted that water vapor levels will increase (NASA 2004, IPCC 2007). Water vapor is involved in an important climate feedback loop. As the temperature of the earth's surface and atmosphere increases, the atmosphere is able to hold more water vapor. The additional water vapor, acting as a greenhouse gas, absorbs long-wave radiation that would otherwise escape to space and thus causes further warming (water vapor feedback). However, a NASA funded study has found that the increases in water vapor were not as high as the climate-forecasting models have assumed. For that reason, some climate forecasts may be overestimating future temperature increases (NASA 2004).

Relative humidity is determined by explicitly resolved dynamic processes, and undergoes marked spatial and temporal fluctuations. Nonetheless, all models studied to date produce a positive water vapor feedback consistent with the assumption that water vapor increases in such way as to keep the relative humidity approximately unchanged at all levels (IPCC 2001). A recent study by WILLETT (2007) has shown that relative humidity may remain near constant at all scales but that there are significant trends for some regions suggesting that the supposition of near-constant relative humidity is not always valid. However, on regional scales where precipitation is predicted to decline and moisture is limited, relative humidity is likely to decrease. Especially during longer and more intense summer droughts, as predicted for large regions of Europe, relative humidity will be lowered by less or no precipitation and by elevated temperatures (ROWELL \& JONES 2006).

\section{Climate change effects on vegetation and plant growth}

Climate change will strongly affect natural ecosystems, agriculture and silviculture through changes in regional energy and water balance. For example, the vegetation period has been predicted to increase due to milder winters and reduced frost (IPCC 
2007). For Germany and other parts of Central Europe studies have shown that the vegetation period already increased by more than 10 days since 1950 (UEA 1999). As rainfall patterns become more unpredictable, plants will be subjected to increasing fluctuations in soil water availability. Reduced soil water availability will reduce water uptake by plants, and can also restrict nutrient uptake by roots and transport to the shoots. Studies have shown that even very small reductions in water and nutrient availability significantly reduce plant growth (e.g., KHALIL \& GRACE 1992, KRAMER \& BOYER 1995, ARNDT et al. 2001, STEVENS et al. 2004). Excessive precipitation resulting in inundation of soils is likely to reduce the partial pressure of oxygen around the roots of plants, which usually reduces their hydraulic conductivity, thereby reducing water uptake. As a result, plant water deficits can occur, even when there is plenty of water in the soil (JACKSON et al. 1995).

While numerous studies have investigated the impact of elevated $\mathrm{CO}_{2}$-concentrations (HÄTTENSCHWILER \& KÖRNER 2000, HAMILTON et al. 2002, NORBY et al. 2002), elevated temperature (ERICE et al. 2007, TUNGATE et al. 2007), changed precipitation and drought periods (FOTELLI 2002, GESSLER et al. 2004, ERICE et al. 2007, GESSLER et al. 2007) on plant growth in climate chamber and greenhouse experiments, as well as in field experiments (HÄTtensCHWILER \& KöRNER 2000, HollisteR \& WebBER 2000, SPINNLER \& KÖRNER 2002, KÖRNER et al. 2005), no study has included possible changes in the status of atmospheric water. Lowered air humidity during longer or more intense drought periods is likely to have additional negative effects on plant growth besides the negative effect of soil water depletion. Ecosystems with generally high air humidity, and plants sensitive to drought stress may be especially handicapped by lowered air humidity conditions.

\section{The forest floor - an environment with generally high air humidity}

The forest floor environment is characterized by low light, damped temperature fluctuations and generally high air humidity. Several species growing in this microclimate have adapted to these conditions as is indicated by the species-rich woodland herb floras of temperate forests on nutrient-rich soils (RoGERS 1982, ELLENBERG 1996). Thin and hygromorphic leaves, high shade-tolerance but sensitivity to high irradiance, and susceptibility to soil drought are typical for many woodland herb species (Ellenberg 1939, Rehder 1960, Hoflacher \& Bauer 1982, PeAce \& GRUBB 1982). 
On a small scale, the relief can modify the microclimate near the ground and can lead to changes in chemical and physical soil properties in different topographic positions inside the forest. Therefore, the distribution, abundance, and cover of woodland herbs depend on several biotic and abiotic factors. Relevant biotic factors that control the composition of the forest floor vegetation include dispersal abilities, competition, disturbance regime, and herbivory. The most important abiotic factors influencing the forest floor vegetation were found to be soil moisture (GRAAE \& HESKJAER 1997, PAUSAS \& AUSTIN 2001, GÁLHIDY et al. 2006), topography, soil chemistry (ANDERSSON 1993, FALKENGREN-GRERUP \& TYLER 1993, SVENNING \& SKOV 2002, NORTH et al. 2005), and the light regime (MARTENS et al. 2000, RANKIN \& TRAMER 2002, GÁLHIDY et al. 2006, JELASKA et al. 2006). The distribution of woodland herbs has been found to be determined by soil moisture. Herb cover and species richness have been found to increase with increasing soil water availability (RUNKLE \& WHITNEY 1987, PAUSAS \& AUSTIN 2001, HÄRDTLE et al. 2003, GÁLHIDY et al. 2006, HOKKANEN 2006). Besides water availability, soil nutrient availability plays an important role for forest herbs, and soil nutrient deficiencies, especially of nitrogen, have been found to limit growth in several Central European woodland herb species. Forest herbs are therefore very nitrogen-efficient, while light in spring is highly available, soil nutrients are used in large quantities to produce leaves with a high $\mathrm{N}$ concentration and presumably at high photosynthetic rates. At this time, the plants achieve a high return of carbon from $\mathrm{N}$ invested in leaves. After spring, when the canopy is closed and light is scarce, $\mathrm{N}$ is withdrawn without affecting the presumably lower photosynthetic rate caused by low light (JONASSON \& WIDERBERG 1988). Therefore, radiation has been found (besides its direct effect on plant growth) to be very important for the forest floor vegetation. However, the importance of light is consequently dependent on the soil water and nutrient availability in the forest (HÄRDTLE et al. 2003), suggesting that light supply is less important in forests on moist, nutrient-rich soils.

Some authors have also pointed out the importance of the quality and thickness of the organic layer (AHLGREN \& AHLGREN 1981, FACELLI \& PICKETT 1991 a,b). A high amount of organic material reduces the light for those species that are growing on the forest floor and can therefore have a negative effect on several species. SCHMID \& LEUSCHNER (1998) explained the absence of forest floor vegetation in a beech forest on gypsum soil with the presence of a $20 \mathrm{~cm}$ thick organic layer. In contrast, other species that are able to grow through the organic layer may have a competitive benefit over fast growing species that are not able to penetrate a thick organic layer (SYDES \& 
GRIME 1981, ERIKSSON 1995). Some species may even depend on a thick organic layer because it stores water and helps to prevent soil drying (SYDES \& GRIME 1981).

While several abiotic and biotic factors were investigated (as described above) for their influence on the distribution of temperate woodland herbs, air humidity was neglected. The forest interior has a higher water vapor pressure than open habitats because of lower air mixing with higher, drier air layers (FLEMMING 1982). Consequently, air humidity is also higher in the forest interior than in open habitats, not only because of the higher water vapor pressure, but also due to lower temperatures in the forest interior. Air humidity in the forest is mainly determined by the local temperature regimes. For example, in the cooler trunk area and on the forest floor, air humidity is high, whereas it is lower in the tree tops (GEIGER et al. 1995). Variation of air humidity on a small scale can further occur due to the relief. For example, on south-facing slopes air humidity is lower due to higher temperatures, while it is higher on northfacing slopes due to lower temperatures. How the distribution of woodland herbs on the forest floor is determined by small variations of air humidity is not known because no study has systematically investigated the role of air humidity on the forest floor.

\section{The influence of air humidity on plant growth and physiology}

Studies focusing on the effect of air humidity, or the vapor pressure deficit of the air (VPD), on plant growth and physiology have focused mainly on two topics: (i) the influence of air humidity on growth and development of horticultural and agricultural plant species (e.g., KRIZEK et al. 1971, MORRISON-BRAID \& WEBSTER 1978, GAFFNEY 1978, VAN DE SANDEN 1985), and (ii) the short-term effects of the atmospheric moisture on physiological parameters, e.g., stomatal responses (e.g., LANGE et al. 1971, FARQUHAR 1978, MOTT \& PARKHURST 1991, FRANKS et al. 1997).

The great majority of studies with economic plants found a decreased growth rate of $40 \%$ to $90 \%$ when VPD increased from low to medium or high levels (NIGHTINGALE \& MITCHELL 1934, WENT 1957, HOFFMAN et al. 1971, KRIZEK et al. 1971, FORD \& THORNE 1974, TibBitTs \& BotTenberg 1976, WoOdWARd \& Begg 1976, HofFMAN \& JOBES 1978, HUNTER et al. 1985, SALIM 1989, GISLERÖD \& MORTENSEN 1990, MORTENSEN \& GISLERÖD 2000, CODARIN et al. 2006). Only a limited number of studies found no influence of air humidity on biomass production (O'LEARY \& KNECHT 1971, FORD \& THORNE 1974, HOFFMAN \& JOBES 1978). In contrast to many studies with economic plants, only a few studies focused on the effect of air humidity on growth and development of wild plants. In a study by LEUSCHNER (2002), temperate woodland 
herbs of European beech forests were grown in climate chambers with contrasting VPD levels over a period of three months. In seven of the eight species, biomass increased with an increase in the atmospheric moisture. In trees and tree seedlings, biomass production was found to increase or decrease when VPD was lowered (SALE 1970, BALL et al. 1997, DARLINGTON et al. 1997, ROBERTS \& ZWIAZEK 2001, CUNNINGHAM 2006). Studies that have shown a decreasing biomass production under lowered air humidity have often found a decrease in total leaf area (PRISCO \& O'LEARY 1973, FORD \& THORNE 1974, LEUSCHNER 2002, CODARIN et al. 2006), specific leaf area (MORTENSEN et al. 2001), and leaf water content (RIJN et al. 2000, NEJAD \& MEETEREN 2007). Several studies found no effect of air humidity on the root/shoot ratio (LEUSCHNER 2002, WERNEYER 2003, CUNNINGHAM 2006). In contrast, MORTENSEN et al. (2001) reported a decrease in root/shoot ratio in roses when grown under elevated atmospheric moisture.

All studies, both with economic and wild plants, which have investigated the effect of air humidity on plant growth and development, were conducted as climate chamber or greenhouse experiments. Studies focusing on the effect of air humidity on plant growth and establishment under field conditions have not been conducted so far.

In contrast to the predominant positive effect of air humidity on plant growth, extremely high air humidity has been found to have a negative effect (CUNNINGHAM 2006). Possible causes for this negative effect might be the reduction of transpiration rate that results in reduced water transport in the plant and which may cause nutrient deficiency (SALIM 1989). Furthermore, it has been shown that very high air humidity levels increase the incidence of plant diseases (GRANGE \& HAND 1987), and increase the infection rate by pathogens (WALLER 1976, GHORBANI et al. 2006).

The influence of air humidity on the parameters of plant physiology was investigated mainly in short-term studies, in which the response of stomata to VPD was the most often investigated parameter. Numerous studies have reported on the sensitivity of stomata to air humidity (e.g., LANGE et al. 1971, FARQUHAR 1978, KAPPEN et al. 1987, GRANTZ \& MEINZER 1990, MONTEITH 1995). Early studies concluded that stomata respond to leaf water status and that responses to air humidity were hydraulic feedback responses to reduced leaf water potentials that resulted from an increased transpiration rate in drier air. In contrast, several studies have shown that a feed-forward response of the stomata to air humidity is also possible (SCHULZE et al. 1972, FRANKS \& FARQUHAR 1999). The feed-forward response was explained by transpiration that bypassed the stomata, either to "peristomatal transpiration" (LANGE et al. 1971, MAIER- 
MAERCKER 1983) or water loss through the cuticula (SHERIFF 1984). MOTT \& PARKHURST (1991) suggested that the feed-forward response may result from patchy stomatal closure, while other studies have found the possibility of feed-forward response in the absence of stomatal closure (FRANKS et al. 1997). MACFARLANE et al. (2004) recently showed that the mechanism that controls stomatal closure, especially the apparent feed-forward response under a high leaf-to-air vapor pressure deficit is less clear. Some authors have suggested that the phytohormon abscisic acid (ABA) might play a role in the feed-forward response of stomata to VPD (FRANKS et al. 1997). Although the role of $A B A$ is well established in the response of stomata to soil drought (e.g., ZHANG et al. 1987, TARDIEU \& DAVIES 1992, GoWING et al. 1993, TARDIEU et al. 1993, THOMPSEN et al. 1997, JIA \& DAVIES 2007), its involvement in stomatal response to VPD in the absence of soil water depletion is poorly investigated so far (MACFARLANE et al. 2004).

There is also an extensive literature about possible effects of VPD on the photosynthetic apparatus (BALL \& FARQUHAR 1984, RESEMANN \& RASCHKE 1984), and the control of transpiration and leaf conductance. Under constant levels of a higher VPD, leaf transpiration rate has been found to remain elevated in several studies (HIRASAWA \& HSIO 1999, RAY et al. 2002), even though leaf conductance was found to be reduced (TURNER et al. 1985, MAROCO et al. 1997, FRANKS \& FARQUHAR 1999, BUNCE 2000, ROBERTS \& ZWIAZEK 2001, RAY et al. 2002). Changes in transpiration rate have been found to cause reductions in leaf water potential and leaf turgor (SHACKEL et al. 1987, FRENSCH \& SCHULZE 1988) which in turn may limit leaf expansion. Leaf expansion rates were observed to increase with decreased VPD over short time periods (BEN HAJ SALAH \& TARDIEU 1996, CLIFTON-BROWN \& JONES 1999).

Decreased leaf conductance may decrease net photosynthesis in many species which in turn results in reduced growth rates (CUNNINGHAM 2006). A reduction of photosynthesis as a direct consequence of lowered VPD, independently from soil water status, was found by several authors (KHAIRI \& HALL 1976, TURNER et al. 1985, DAl et al. 1992, FRANKS \& FARQUHAR 1999, ROBERTS \& ZWIAZEK 2001). Other investigations additionally found a decreased nutrient uptake under elevated VPD (COLLATZ et al. 1991, WIESER \& HAVRANEK 1996). However, regarding the influence of different VPD levels on plant nutrient uptake and plant element concentrations, different tendencies have been recorded. While some studies have found increased shoot element concentrations under high VPD levels (NIEMAN \& POULSEN 1967, GISLERÖD et al. 1987, SALIM 1989, GISLERÖD \& MORTENSEN 1990, MARSCHNER 1995), other studies reported 
little or no change (GALE \& HAGAN 1966, TROMP \& OELE 1972, ERLANDSSON 1975), or a decrease in concentrations (BRAFIELD \& GUTTRIDGE 1984, COLLIER \& TIBBITTS 1984). LEUSCHNER (2002) reported that higher shoot nutrient concentrations at higher VPD levels were a result of a nutrient dilution effect caused by decreased carbon assimilation in plants that were grown under high VPD. However, he found no correlation between transpiration rate and shoot nutrient concentrations as it was reported in other studies (GISLERÖD et al. 1987, GISLERÖD \& MORTENSEN 1990, MARSCHNER 1995).

A review of the literature shows that the influence of air humidity on plant growth and physiology has been investigated in many studies, but that most of these studies have focused on only certain aspects and did not compare the influence of air humidity on various growth related traits. For example, the studies that focused on short-term effects of VPD on physiological parameters (e.g., stomatal sensitivity) largely ignored longer time responses. On the other hand, studies that focused on the influence of atmospheric moisture on plant growth have often included only a few or no physiological measurements. Another problem is that there is a general lack of studies that investigated air humidity independently from the soil moisture status. This makes it difficult to understand how plants are influenced by contrasting air humidity conditions because of confounding soil moisture effects. Finally, studies that investigated the influence of air humidity on plant growth and physiology under field conditions are completely missing. 


\section{Study aim}

As described above, there is a lack of studies that have investigated the effect of air humidity on plant growth and physiology in long-term studies. Moreover, most of the studies have not focused on wild herbs and trees. Additionally, the effect of air humidity on plants was not investigated independently from other factors under field conditions. An extrapolation of climate chamber results to the forest floor environment is therefore a difficult task. Furthermore, from climate chamber experiments alone it is not possible to give a prognosis of how woodland herbs and tree saplings will react to alterations in air humidity, as a consequence of a drier climate resulting from climate change.

This study investigated the effect of air humidity on temperate woodland herbs and European beech saplings by combining climate chamber and field experiments with an observational study in the field.

Major aims of the study were:

(i) to investigate long-term effects of contrasting VPD levels on temperate woodland herbs and beech saplings in climate chamber and field experiments,

(ii) to test if reduced air humidity, acting independently from soil moisture status, exerts a negative growth-reducing effect on temperate woodland herbs and beech saplings,

(iii) to test if the distribution and abundance of temperate woodland herbs is influenced by air humidity. 
The effect of air humidity on development, physiology, and distribution of woodland herbs and beech saplings was investigated in a combination of experiments and observational field studies. Air humidity was either manipulated in climate chambers or in open-top chambers on the forest floor, or investigated in the natural climate on the forest floor:

\section{Climate chamber experiment}

- Manipulation of air humidity under artificial conditions

- Investigation of the influence of air humidity on growth and physiology of woodland herbs (chapter 3 ) and beech saplings (chapter 4)

\section{Open-top chamber experiment}

- Manipulation of air humidity under natural conditions

- Investigation of the influence of air humidity on growth and vitality of woodland herbs (chapter 3 ) and beech saplings (chapter 4)

\section{Observational field study}

- Natural conditions, comparison of a large number of woodland sites

- Investigation of the role of air humidity as a site factor for woodland herbs in comparison to other abiotic factors (chapter 5) 


\section{Chapter 2}

\section{Material and methods}

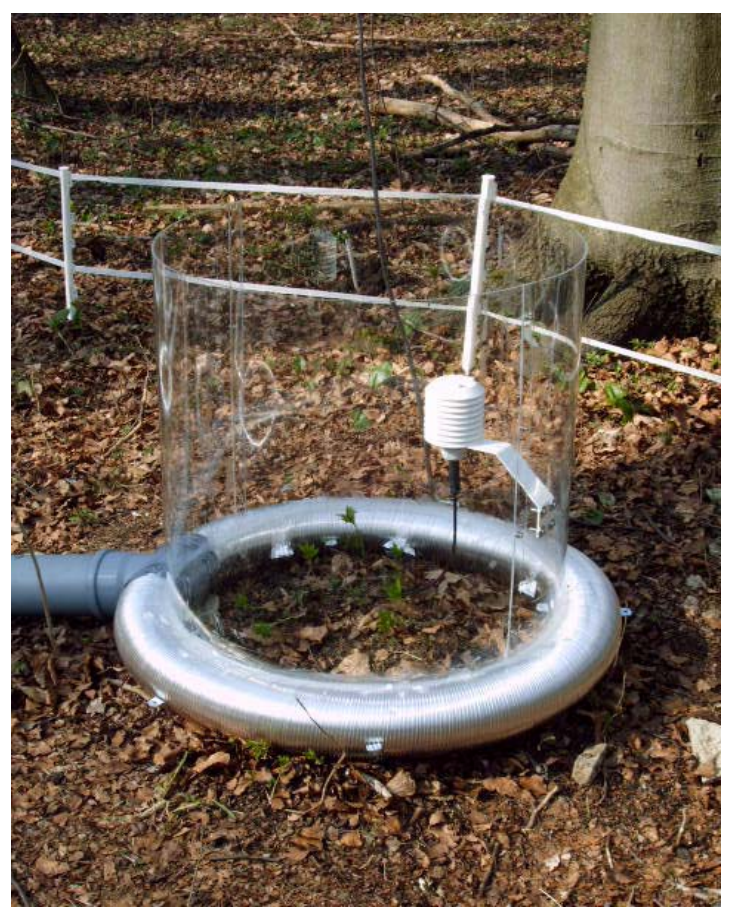




\section{Overview}

The study was divided into an experimental investigation and an observatorial field study. In the experimental investigation, the effects of air humidity on plant growth and physiology were either studied in climate chambers with contrasting air humidity levels, or air humidity was manipulated in open-top chambers on the forest floor. In the field study, the importance of air humidity on the distribution of woodland herbs in temperate forests was analyzed through a correlative approach, and the influence of air humidity was compared to that of other abiotic factors.

\section{Experimental investigation of the influence of air humidity on plants}

In the climate chamber and open-top chamber experiments, either two temperate woodland herb species, or saplings of European beech (Fagus sylvatica L., Fagaceae), were investigated. The woodland herbs selected were Mercurialis perennis L. (Dog's mercury, Euphorbiaceae) and Stachys sylvatica L. (Hedge woundwort, Lamiaceae). The plants were cultivated from seeds ( $F$. sylvatica and S. sylvatica) or from rhizome sections of uniform size (M. perennis). After cultivation in a greenhouse, the plants were transferred either to the climate chambers or to the open-top chambers in the field.

\section{Climate chamber experiment}

In the climate chamber experiment, the plants were cultivated in nutrient solutions to guarantee a defined and non-limiting soil moisture and nutrient supply regime. Two climate chamber experiments were performed to investigate the woodland herb species and the beech saplings. The plants were grown for a period of three months in climate chambers at constant vapor pressure deficits of 350 (treatment $A$ ), 930 (B), and $1400 \mathrm{~Pa}(\mathrm{C})$ in the 14-hour light phase, and at 250, 712, and $1068 \mathrm{~Pa}$ in the 10-hour dark phase. This corresponds to an air humidity of $85 \%, 60 \%$, and $40 \%$ in the treatments $A, B$ and $C$, respectively (Table 1 ). 
Table 1: Relative humidity $(\mathrm{RH})$, air temperature, saturation vapor pressure $(\mathrm{E})$, actual vapor pressure (e) and VPD in the three climate chamber treatments A-C during the $14 \mathrm{~h}$ day period and the $10 \mathrm{~h}$ night period. Air humidity and temperature where controlled during the whole experiment with thermo-hygrographs.

\begin{tabular}{lccccc}
\hline Treatment & $\mathbf{R H}[\%]$ & $\mathbf{T}\left[{ }^{\circ} \mathbf{C}\right.$ ] & $\mathbf{E}[\mathrm{Pa}]$ & $\mathbf{e}[\mathbf{P a}]$ & VPD [Pa] \\
\hline A (night) & 40 & 15 & 1785 & 712 & 1068 \\
A (day) & 40 & 20 & 2337 & 935 & 1400 \\
B (night) & 60 & 15 & 1785 & 1068 & 712 \\
B (day) & 60 & 20 & 2337 & 1400 & 930 \\
C (night) & 85 & 15 & 1785 & 1513 & 250 \\
C (day) & 85 & 20 & 2337 & 1986 & 350 \\
\hline
\end{tabular}

The relative air humidity $(\mathrm{RH})$ relates the actual concentration (or actual pressure) of water vapor in the air to the concentration of water vapor at saturation:

$$
\begin{aligned}
& \mathrm{RH}=\mathrm{e} / \mathrm{E}{ }^{*} 100 \% \\
& \mathrm{e}=\text { actual vapor pressure }[\mathrm{Pa}] \\
& \mathrm{E}=\text { saturation vapor pressure }[\mathrm{Pa}]
\end{aligned}
$$

The water vapor saturation deficit (VPD) quantifies the amount of water needed to saturate the air:

$$
\mathrm{VPD}=\mathrm{E}-\mathrm{e}[\mathrm{Pa}]
$$

The saturation vapor pressure can be approximated with the Magnus equation:

$$
\begin{aligned}
& \mathrm{E}=6.1 \mathrm{hPa}^{*} 10^{\left[\left(7.5^{*} \mathrm{~T}\right) /(\mathrm{T}+237)\right]} \\
& \mathrm{T}=\text { Temperature }\left[{ }^{\circ} \mathrm{C}\right]
\end{aligned}
$$

Air temperature in all three treatments was $20^{\circ} \mathrm{C}$ in the $14 \mathrm{~h}$ light phase and $15^{\circ} \mathrm{C}$ in the $10 \mathrm{~h}$ dark phase. The quantum flux density during the light phase was $142( \pm 10)$ $\mu \mathrm{mol} \mathrm{m} \mathrm{m}^{-2} \mathrm{~s}^{-1}$.

\section{Open-top chamber experiment}

In order to simulate a drier climate on the forest floor with reduced air humidity while maintaining other growth conditions constant, an open-top chamber system suitable for field manipulation experiments on the forest floor was developed. The system consisted of sixteen circular open-top chambers and was established on the forest floor of the Göttinger Wald beech forest east of Göttingen $\left(51^{\circ} 32^{\wedge} \mathrm{N}, 10^{\circ} 03^{`} \mathrm{E}\right)$. With the 
system it was possible to investigate two species at the same time, while eight chambers (four per species) were treated with ambient air (control) and eight (four per species) with air containing reduced water vapor. Two large radial fans (one per treatment) produced a steady air flow through the chambers. To reduce air humidity, two absorption air driers (Resuscorb, DST Seibu Giken, Sweden) were used, which decreased air humidity constantly by up to $15 \%$ in relative humidity compared to the control chambers. The air was channelled to the chambers through plastic pipes, and entered them through eight perforated tubes at the bottom of the chamber. To guarantee a comparable air temperature in the chambers, the temperatures of the dried and the ambient air stream were matched by the use of a cross flow heat exchanger (Duplexvent 15000, Airflow Lufttechnik GmbH, Rheinbach, Germany).

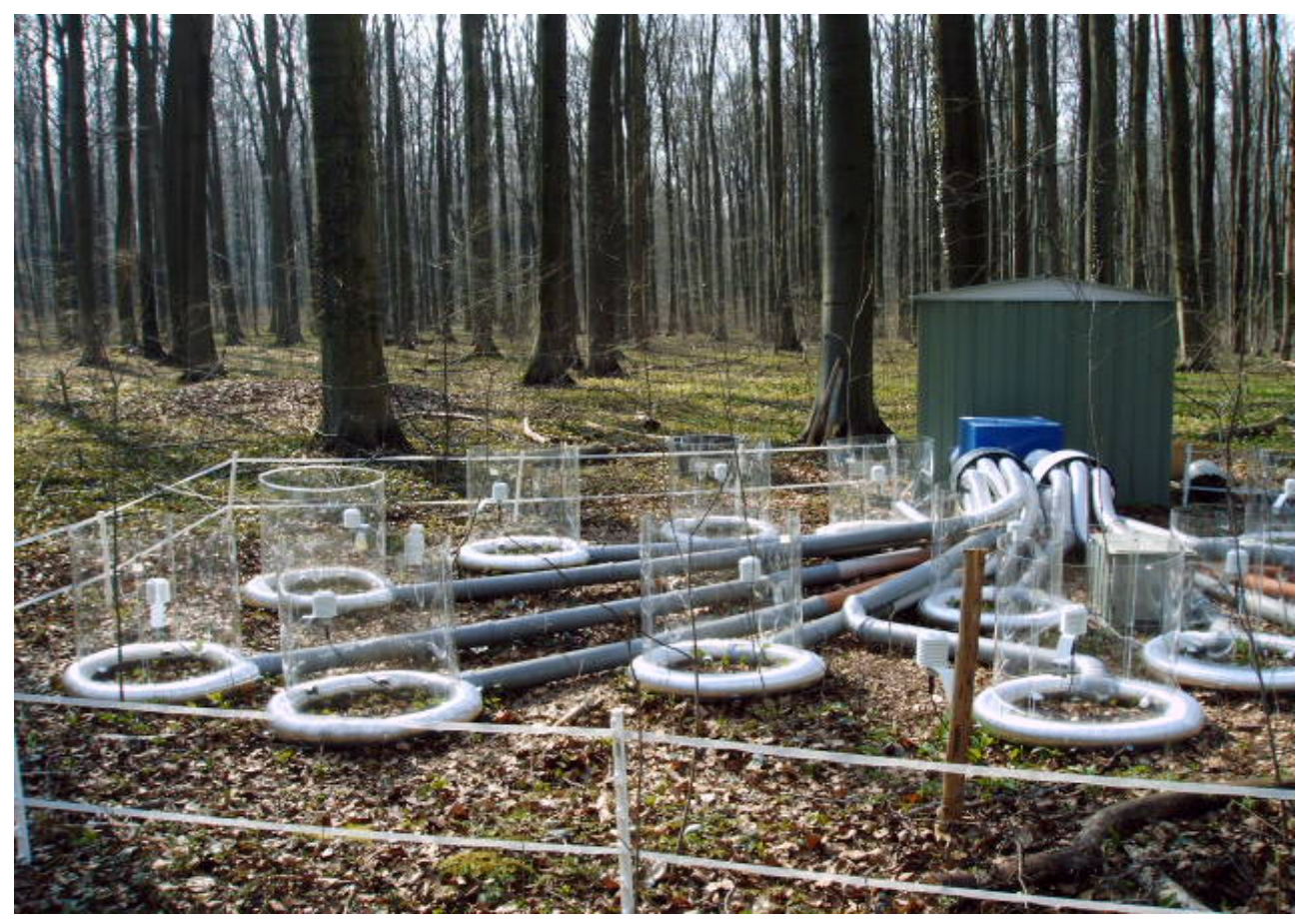

Fig. 1: The open-top chamber experiment on the forest floor of the Göttinger Wald beech forest.

In each chamber, seven ( $F$. sylvatica) or eight ( $M$. perennis, S. sylvatica) plants were grown for a period of 80 days (herb species) or one year (beech saplings). The two woodland herb species were directly planted into the chambers, whereas seedlings of beech were planted within a fence to protect the roots and shoots from rodents (Fig. 2).

To ensure that no significant differences in soil moisture existed between the chambers, small amounts of water were applied to the soil of each chamber if the soil moisture deviated from a target soil moisture level of $40 \mathrm{vol} \%$. 

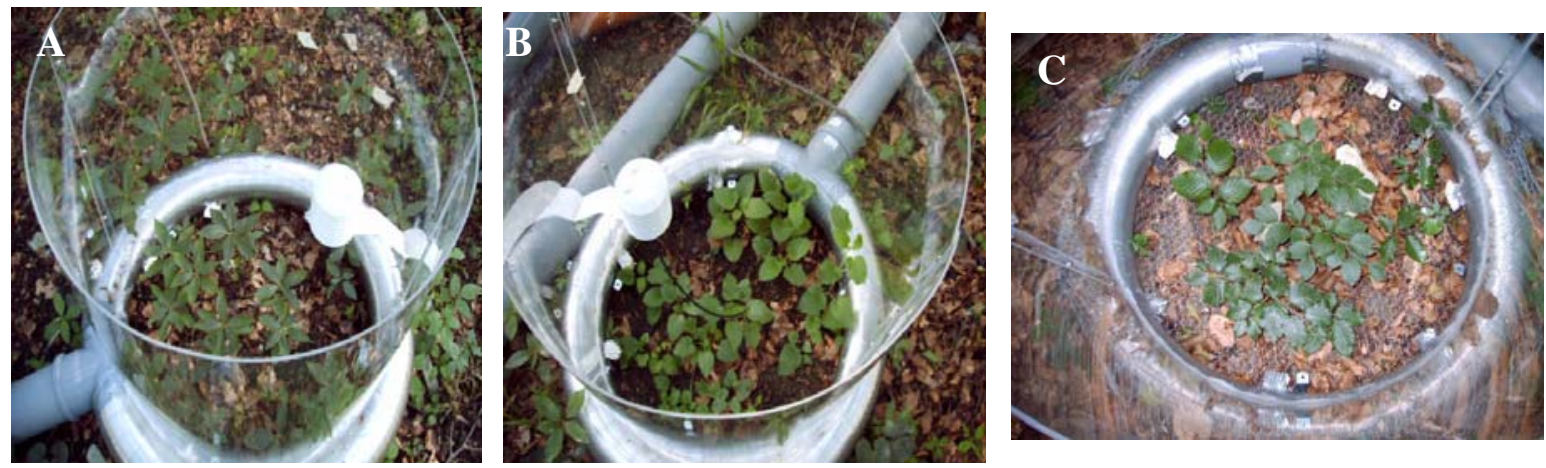

Fig. 2: Open-top chambers with the investigated species. Mercurialis perennis (A) and Stachys sylvatica $(B)$ were directly planted into the soil, whereas saplings of Fagus sylvatica $(C)$ were planted within a fence to protect the roots and shoots from rodents.

Air humidity in the chambers treated with dry air was on average $15 \%$ lower than in the chambers treated with ambient air (control). On cloudy, relatively humid days, the air humidity was reduced by about $20-22 \%$ (Fig. $3 A$ ), while on sunny days when the ambient air humidity was only $50 \%$, the air humidity was reduced by about $10 \%$ (Fig. $3 C$ ). On cloudy days, the ambient air humidity in the chambers (control) was very similar to the measured air humidity outside the chambers on the forest floor. In contrast, on sunny days, air humidity in the control chambers was on average $5-10 \%$ lower than on the forest floor (outside the chambers). The differences between the control chambers and the forest floor were due to a somewhat higher temperature in the open-top chambers than on the forest floor (Fig. 3B, D). 


\section{Cloudy day}
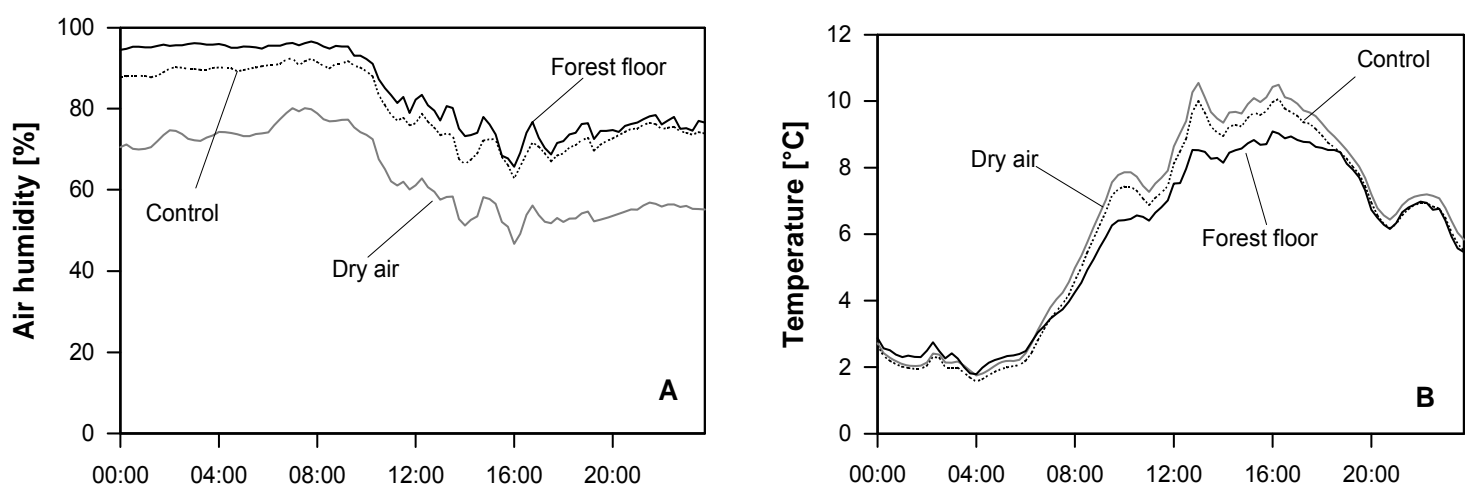

Sunny day
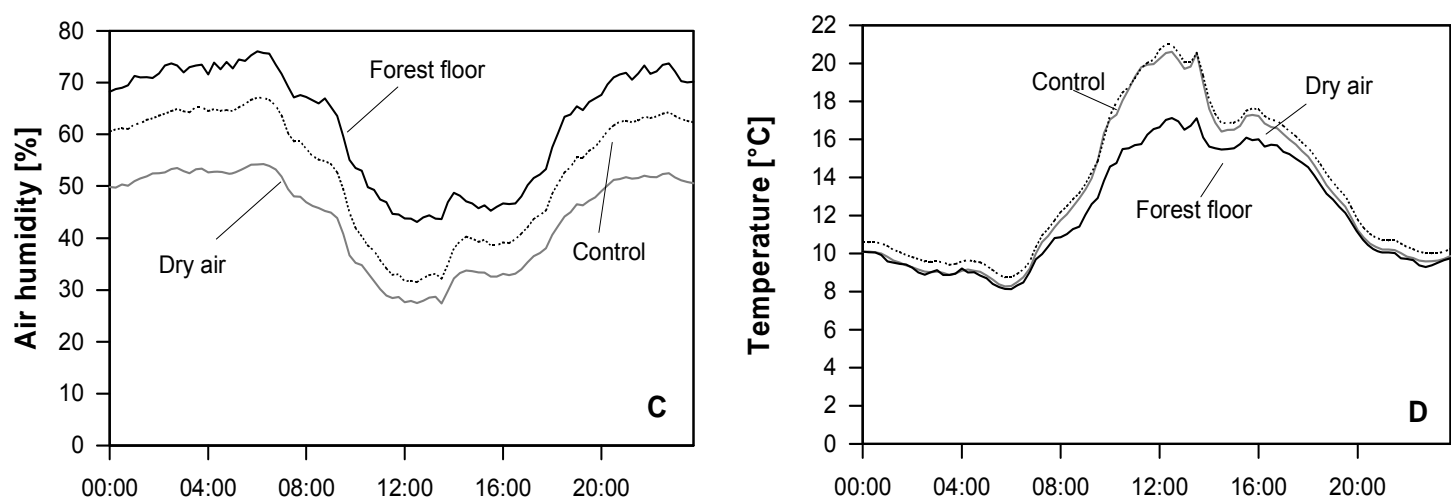

Fig. 3: Air humidity and air temperature measured inside the open-top chambers treated with atmospheres of ambient air humidity (control) or reduced air humidity (dry air), and outside the chambers on the forest floor. Values are given for the cloudy April 9, 2005 (A, B) and for the sunny April 14, 2005 (C, D). 


\section{Investigated parameters}

In both experiments, several parameters were measured including biomass production (above- and below-ground), leaf development (total leaf area, average leaf size, number of leaves and buds) and leaf $\delta^{13} \mathrm{C}$-signature (Table 2). Physiological measurements included leaf water potential, leaf turgor, osmotic potentials, leaf conductance and leaf transpiration rate (description of the methods: see chapter 3 and chapter 4).

Table 2: Selected parameters that were measured in the three investigated species in the climate chamber and open-top chamber experiment.

\begin{tabular}{|c|c|c|c|c|c|c|}
\hline & $\begin{array}{c}\text { Biomass } \\
\text { production }\end{array}$ & $\begin{array}{c}\text { Leaf } \\
\text { development }\end{array}$ & $\begin{array}{c}\text { Leaf } \\
\text { water } \\
\text { potential }\end{array}$ & $\begin{array}{l}\text { Leaf } \\
\text { turgor }\end{array}$ & $\begin{array}{c}\text { Leaf } \\
\text { conductance }\end{array}$ & $\begin{array}{c}\text { Leaf } \\
\text { transpiration } \\
\text { rate }\end{array}$ \\
\hline \multicolumn{7}{|c|}{ Climate chamber } \\
\hline M. perennis & $x$ & $x$ & $\mathrm{X}$ & & $\mathrm{x}$ & $x$ \\
\hline S. sylvatica & $\mathrm{x}$ & $x$ & $X$ & & $\mathrm{x}$ & $x$ \\
\hline F. sylvatica & $\mathrm{x}$ & $\mathrm{x}$ & $\mathrm{X}$ & $\mathrm{x}$ & $\mathrm{x}$ & $\mathrm{x}$ \\
\hline \multicolumn{7}{|c|}{ Open-top chamber } \\
\hline M. perennis & $x$ & $\mathrm{x}$ & & & & \\
\hline S. sylvatica & $\mathrm{x}$ & $x$ & & & & \\
\hline F. sylvatica & $\mathrm{x}$ & $\mathrm{x}$ & & & & \\
\hline
\end{tabular}

\section{Observatorial field study}

Study area

The field study was conducted in an extensive area of beech forests on calcareous soils (southern Lower Saxony, Central Germany). The altitude in the area varies from 130 to $430 \mathrm{~m}$ a.s.I. Most of the forest consists of a 100- to 130-year-old beech forest with a species-rich herb layer including spring geophytes and shade-tolerant summer herbs and grasses. The climate has a sub-oceanic to sub-continental character. Annual mean temperature is $7.9{ }^{\circ} \mathrm{C}$ with a mean annual rainfall of $720 \mathrm{~mm}$. The bedrock is Triassic limestone; the soils are Rendzina and Terra fusca soils with a mull humus form. The natural forest community of the study area is the Hordelymo-Fagetum beech forest association, which is characterized by a number of woodland herb species with large meso- to hygromorphic leaves. Typical species are Allium ursinum L. (Alliaceae), Mercurialis perennis L. (Euphorbiaceae), Anemone nemorosa L. (Ranuculaceae), Lamiastrum galeobdolon (L.) Ehrend. \& Polatsch (Lamiaceae), Hepatica nobilis Mill. (Ranuculaceae) and Asarum europeaum L. (Aristolochiaceae). 


\section{Study design and field inventory}

In order to investigate the distribution of woodland herbs on a small scale, six different site types with contrasting microclimate and edaphic settings were chosen. For each site type, ten plots à $10 \mathrm{~m} \times 10 \mathrm{~m}$ were selected. Thus, 60 plots with contrasting exposition (north or south), slope angle (low or high) and relief type (valley bottoms, open or sheltered) where chosen. The six site types were: (A) sheltered valleys, (B) open valleys, (C) shallow north-facing slopes, (D) steep north-facing slopes, (E) shallow south-facing slopes, and (F) steep south-facing slopes.

On each of the 60 plots the following parameters were recorded:

- total herb cover and cover and abundance of selected forest herb species,

- inclination of the plot,

- air humidity and air temperature,

- the flux density of photosynthetically active radiation (PAR),

- soil moisture, and

- soil chemical properties.

Air humidity and temperature were recorded during the whole spring season 2006 with micro-weather stations consisting of air temperature and capacitative air humidity sensors (DS 1923, Maxim/Dallas, USA) equipped with a self-made radiation shield. Soil moisture and PAR were determined weekly, while soil chemical properties were analyzed once at the end of the study (see chapter 5).

\section{Statistical analysis}

In order to detect the most important environmental factors which control the density and species composition of the forest floor vegetation, and to compare the importance of air humidity and other abiotic factors, a canonical correspondence analysis was used. To test for the influence of the measured abiotic factors on selected species, a multiple regression analysis was conducted additionally (see chapter 5). 


\section{Chapter 3}

Temperate forest herbs are adapted to high air humidity -

evidence from climate chamber and humidity manipulation experiments in the field

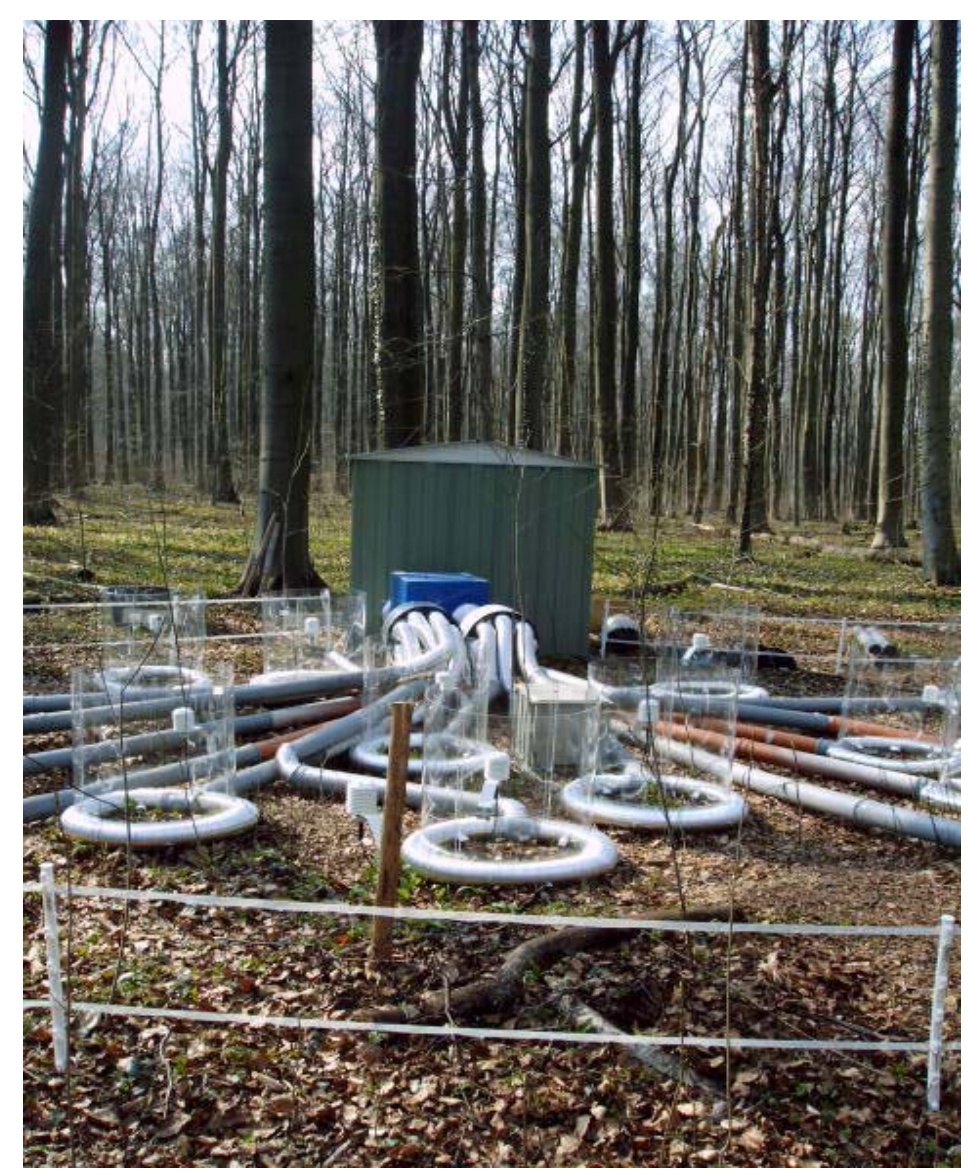




\begin{abstract}
How growth and morphology of wild plants are controlled by the water vapor saturation deficit of the air (VPD) is not sufficiently understood. The hypothesis that VPD acts on temperate woodland herbs independently from soil moisture, was tested by experimentally exposing two hygromorphic woodland species (Mercurialis perennis and Stachys sylvatica) to variable VPD levels in climate chambers with hydroponic culture, and in open-top chambers on the forest floor. A decrease in relative air humidity from $85 \%$ to $40 \%$ in the climate chamber experiment, simulating a microclimate change after canopy gap creation, resulted in a $40 \%$ decrease in dry mass production of the two tested species which were grown in the hydroponic culture. This result is supported by the more realistic open-top chamber experiment on the forest floor which showed a productivity decrease by about $25 \%$ when plants were continuously exposed to an atmosphere with $15 \%$ lower air humidity. Elevated VPD levels reduced plant dry mass production either through a reduced leaf expansion rate or a lower number of formed leaf buds. The present study shows that woodland herbs require sufficiently high air humidity for optimal growth. Gap formation and clear-cutting of forests threaten the vitality and survival of woodland herbs not only by exposing them to excess light, heat stress, and reduced soil water availability, but also through lowered air humidity.
\end{abstract}




\section{Introduction}

Temperate woodland herbs grow in a unique environment which is characterized by low light intensities, damped temperature fluctuations, and generally high air humidity on the forest floor. Thin and hygromorphic leaves, high shade-tolerance but sensitivity to high irradiance, and susceptibility to soil drought are typical for the species of this life form (Ellenberg 1939, Rehder 1960, Hoflacher \& Bauer 1982, PeAce \& GrubB 1982). Plants have been found to produce hygromorphic leaves with a high specific leaf area under various conditions including low light intensity, high air humidity, ample soil moisture supply, or high nitrogen availability. While several studies (e.g., BOGNER 1966, BRATTON 1976, EWALD 1999) have investigated light, soil water, and soil chemistry in their effect on woodland herbs, the influence of air humidity has received little attention. This is surprising because the atmospheric water status has been found to have a significant and often profound influence on plant growth and development in climate chamber and greenhouse experiments (KRIZEK et al. 1971, MORRISON-BRAID \& WEBSTER 1978, GAFFNEY 1978, VAN DE SANDEN 1985). Many studies with agricultural plants showed that plant growth is significantly reduced, and morphology is often altered under extended periods of lowered air humidity (NIEMAN \& POULSEN 1967, HOFFMAN et al. 1971, O`LEARY \& KNECHT 1971, PRISCO \& O`LEARY 1973, WoODWORD \& Begg 1976, hoffmanN \& Jobes 1978, Tibbits 1979, Grange \& Hand 1987, GISLERÖD \& MORTENSEN 1990, MORTENSEN \& GISLERÖD 2000, CODARIN et al. 2006). However, most of these studies manipulated air humidity only for relatively short time spans, and only a few of them dealt with wild plants (e.g., FORD \& THORNE 1974, MARSDEN et al. 1996, RoBERTS \& ZWIAZEK 2001, LEUSCHNER 2002). In a climate chamber study with hydroponic cultures, LEUSCHNER (2002) found that growth and physiology of eight Central European woodland herbs were indeed negatively affected by low air humidity levels. This result implied that air humidity is a relevant environmental factor of the forest floor environment acting independently from the light regime and soil moisture on woodland herbs. Any permanent alteration of the atmospheric water regime in the forest could therefore have consequences for the vitality and abundance of forest herbs, and possibly also for tree seedlings and saplings, if they were sensitive to lowered air humidity as well. However, there are no studies examining the effect of different air humidity levels, independently from other factors, under field conditions in the forest. Simple extrapolation of climate chamber results to the forest is not feasible. 
This study examines the long-term effects of different air humidity levels on the physiology and productivity of two characteristic woodland herb species in a temperate deciduous broad-leaved forest by manipulating atmospheric moisture both in climate chamber and field experiments. A new developed open-top chamber technique was used for altering air humidity in the natural environment of woodland herbs on the forest floor. The hypothesis tested, should prove that reduced air humidity, acting independently from soil moisture status, exerts a negative effect on the physiology and productivity of woodland herbs.

\section{Material and methods}

\section{Plant material}

Two species, widespread in the deep shade of Central European beech forests on calcareous soils, Mercurialis perennis L. (Dog's mercury, Euphorbiaceae) and Stachys sylvatica L. (Hedge woundwort, Lamiaceae), were selected for the study. Both species represent the characteristic growth form with large meso- to hygromorphic leaves in the species-rich herbaceous layer of the Hordelymo-Fagetum beech forest community, which is the potential natural forest community on limestone in the sub-oceanic part of Central Europe. Together with Allium ursinum L. (Alliaceae), Anemone nemorosa (Ranunculaceae) and other herbs, M. perennis and S. sylvatica form dense carpets under the closed canopy of Fagus sylvatica L., spreading mostly by vegetative dispersal. Plant material of both species was collected in the woodlands surrounding Göttingen (Lower Saxony, Central Germany) in the direct vicinity of the open-top chamber experiment. Plants of S. sylvatica were cultivated from seeds, those of $M$. perennis from rhizome sections of uniform size (length: $5 \mathrm{~cm}$ ). For the first seven weeks, the plants were grown in moist sand in a greenhouse at quantum flux densities of $200 \mu \mathrm{mol}$ photons $\mathrm{m}^{-2} \mathrm{~s}^{-1}\left(20{ }^{\circ} \mathrm{C}, \mathrm{VPD}=500-800 \mathrm{~Pa}\right)$. Fifty days later, when the plants were about $4 \mathrm{~cm}$ high, they were transferred either to the climate chambers, or to the open-top chambers in the field. Both species were investigated simultaneously in the climate chamber experiment (winter 2004/2005) and subsequently in the open-top chamber experiment (spring to summer 2005).

\section{Climate chamber experiment}

In the climate chamber experiment, the plants were cultivated in nutrient solutions to guarantee a defined and non-limiting soil moisture and nutrient supply regime. Pots containing $1500 \mathrm{~cm}^{3}$ of solution accommodated one plant each. In order to avoid any shortage of nutrients, complete 0.2x Shive solutions (BAUMEISTER \& ERNST 1978) were 
added once a week. Every two or three days, the $\mathrm{pH}$ of the solution was adjusted to a value of 4.5 . The ionic concentration of the solution was approximately 4 mosmol L-1 equivalent to a water potential of $-0.009 \mathrm{MPa}$. The solutions were continuously ventilated with compressed air.

The experiment consisted of three air humidity treatments ( $A, B$ and $C$ ) with 12 plants each per species and treatment. The plants were grown for 60 days in climate chambers (BBC, Brown Boveri-York, Hamburg, Germany) at constant vapor pressure deficits of 350 (treatment A), 930 (B) and $1400 \mathrm{~Pa}(\mathrm{C})$ in the 14-hour light phase, and at 250, 712 and $1068 \mathrm{~Pa}$ in the 10-hour dark phase. This corresponds to a relative air humidity of $85 \%, 60 \%$ and $40 \%$ in the treatments $A, B$ and $C$, respectively. Air temperature was $20( \pm 1){ }^{\circ} \mathrm{C}$ in the light phase, and $15( \pm 1){ }^{\circ} \mathrm{C}$ in the dark phase. Air humidity was continuously monitored with thermo-hygrographs in the chambers. For simulating realistic below-canopy light regimes, sets of FLUORA lamps (Osram Inc.) were installed in the chambers which provided a constant quantum flux density of 142 $( \pm 10) \mu \mathrm{mol} \mathrm{m}-2 \mathrm{~s}^{-1}$ during the light phase. Measurements with quantum sensors in Central German beech forests had shown that quantum flux density on the forest floor ranged between 100 and $300 \mu \mathrm{mol} \mathrm{m}-2 \mathrm{~s}^{-1}$ before leaf flushing of the beech trees, and between 10 and $30 \mu \mathrm{mol} \mathrm{m} \mathrm{m}^{-2} \mathrm{~s}^{-1}$ after leaf development (Table 1).

\section{Open-top chamber experiment}

In order to simulate a forest floor environment with a reduced air humidity while maintaining other growth conditions constant, an open-top chamber system suitable for field manipulation experiments on the forest floor was developed. In its basic design, the system is similar to open-top chambers used for exposing patches of grassland to elevated $\mathrm{CO}_{2}$ (HÄTTENSCHWILER \& KöRNER 2000, HolLISTER \& WEBBER 2000). Sixteen circular open-top chambers were established in the spring of 2005 on the forest floor of the Göttinger Wald beech forest east of Göttingen $\left(51^{\circ} 32^{`} \mathrm{~N}, 10^{\circ} 03^{\circ} \mathrm{E}\right)$. Each chamber had a diameter of $65 \mathrm{~cm}$ and was manufactured from cylindrical, 2-mm-thick UVtransmissive plexiglass of $60 \mathrm{~cm}$ height (Fig. 1). The chambers were arranged in a random pattern on the forest floor. Eight chambers (four per species) were treated with ambient air (control) and eight (four per species) with air containing reduced water vapor. 


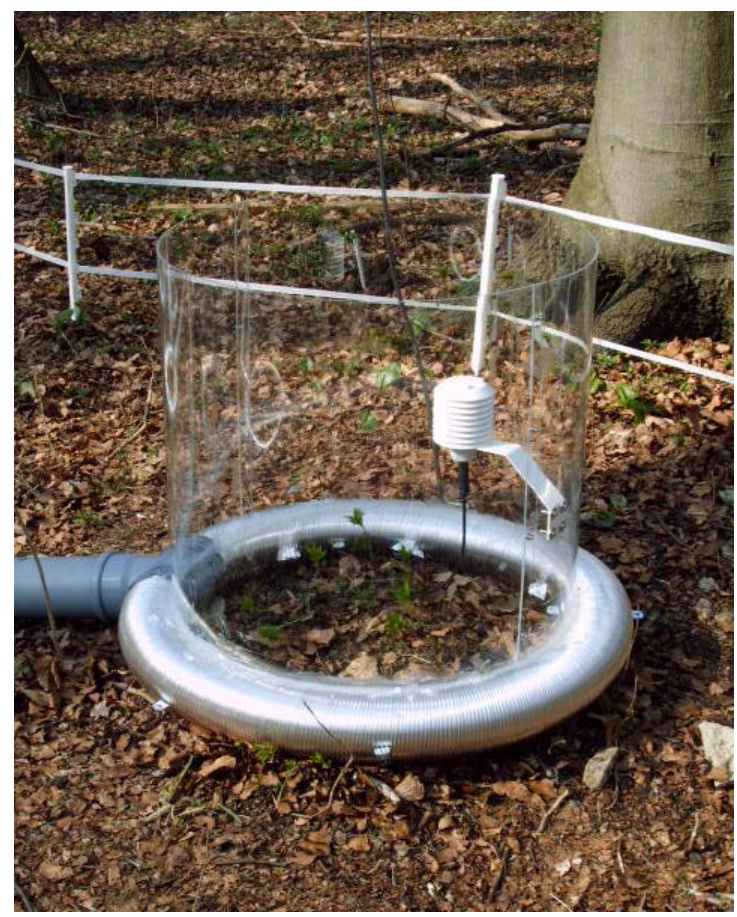

Fig. 1: Open top chamber for air humidity manipulation on the forest floor with microclimate sensor module.

Two large radial fans (one per treatment) produced a steady air flow through the chambers. The air flow was adjusted in all 16 chambers to a mean of $0.5 \mathrm{~m} \mathrm{~s}^{-1}$ and was controlled continuously; this guaranteed a complete turnover of the air inside the chambers every 30 seconds. To reduce air humidity, two absorption air driers (Resuscorb, DST Seibu Giken, Sweden) were used, which decreased air humidity continuously by up to $15 \%$ in relative humidity compared to the control chambers. The air was channelled to the chambers through plastic pipes, and entered them through eight perforated tubes at the bottom of the chamber. Air humidity and temperature were continuously monitored inside the chambers as well as outside the chambers on the forest floor with capacitive air humidity sensors (Hygroclip, Rotronic AG, Ettlingen, Germany). The data was logged every $15 \mathrm{~s}$ with a Campbell logger (Campbell, Logan, USA). In each chamber, eight plants of each species were grown for a period of 80 days (M. perennis: March to June, S. sylvatica: May to August).

To guarantee a comparable air temperature in the chambers, the temperature of the dried and the ambient air stream was matched by the use of a cross flow heat exchanger (Duplexvent 15000, Airflow Lufttechnik GmbH, Rheinbach, Germany). Soil moisture was monitored two times a week with a mobile TDR probe (trime, Imko, Ettlingen, Germany). To ensure that no significant differences in soil moisture existed between the chambers, small amounts of water were applied to the soil of a chamber if 
the soil moisture deviated from a target soil moisture of $40 \mathrm{vol} \%$. Earlier measurements of the soil conditions had shown that the field capacity for this soil is about $45 \mathrm{vol} \%$ (BENECKE 1982). By keeping the soil moisture higher than 40 vol\%, it was guaranteed that no soil water limitation existed throughout the whole experiment.

\section{Determination of biomass production, leaf area, leaf size and leaf number}

Plants were harvested after 60 (climate chamber experiment) or 80 days (open-top chamber experiment), separated into above- and below-ground organs, oven-dried (72 $\mathrm{h}, 70{ }^{\circ} \mathrm{C}$ ) and weighed. The number of replicate plants was 12 in the climate chamber experiment and 32 in the open-top chamber experiment (4 chambers with 8 plants each). The dry matter production of each plant was calculated as the difference in weight at the beginning and the end of the experiment, the former being measured at a random sample of 10 individuals that were harvested at the first day of cultivation (20 to $40 \mathrm{mg}$ per plant depending on species). Above- and below-ground data were added to obtain total plant dry matter production. In order to determine total leaf area and mean leaf size, all leaves were scanned and analyzed using the image analysis program Win Folia 5.1 a (Régent Instruments Inc., Quebec, Canada).

Determination of leaf water status parameters, leaf $\delta^{13} \mathrm{C}$ signature and shoot nitrogen concentration

Several parameters of leaf water status and water turnover were measured repeatedly in the climate chamber experiment. Measurements of leaf conductance $\left(g_{\mathrm{L}}\right)$ and leaf transpiration $\left(E_{L}\right)$ were conducted on four occasions in the last three weeks before harvest. Two leaves in close vicinity were selected for determination of $g_{L}$ and $E_{L}$ during the sixth and seventh hour of the light period using a steady-state porometer (LI1600, LiCor Inc., Lincoln, NE, USA). Porometer measurements were conducted the abaxial surface of 10-15 fully developed leaves of highest or second-highest insertion per treatment. In the high air humidity treatment (VPD $=350 \mathrm{~Pa})$, the conductance values of the porometer were corrected using independent psychrometer data because the capacitive sensor of the porometer is known to give unreliable VPD readings at high air humidities. To eliminate this error, 2-3 hygrometric measurements at plant height were conducted in each chamber at the beginning of a measuring day; these values were then compared with the readings of the capacitive humidity sensor and used for the correction if deviations were observed.

Measurements of leaf water potential $\left(\Psi_{\mathrm{L}}\right)$ were conducted on the date of harvest during the third and fourth hour of the light period using the pressure chamber 
technique (SCHOLANDER et al. 1965). Fully developed leaves of highest or secondhighest insertion were investigated with 12 replications per species and treatment.

The foliar concentration of nitrogen and the $\delta^{13} \mathrm{C}$ signature of leaves of highest or second highest insertion were analyzed on the date of harvest in the Centre for Stable Isotope Research and Analysis of the University of Göttingen with an elementary analyzer (Carlo Erba, NA 1500, USA) coupled to an isotope ratio spectrometer (Thermo Finnigan, MAT 251, USA). This was done in both the climate chamber and open-top chamber experiments.

\section{Statistical analysis}

The statistical analysis was carried out with SAS 8.2 software (SAS Institute, Cary, NC, USA). All data sets were tested for normal distribution with the Shapiro \& Wilk test. In case of normal distribution, a Scheffé test was used to detect significant differences between means; the Wilcoxon-U-test was used for non-normal distributed data. This was done separately for the two species and the two experiments. Significance was determined at $P \leq 0.05$.

\section{Results}

Microclimate conditions during the open-top chamber experiment

Means of daytime air humidity, temperature and VPD levels are shown in Table 1 for the period before leaf flushing of the trees (Period 1, March 15 to May 15) and after tree leaf flushing (Period 2, May 15 to August 15). Outside the open-top chambers (on the forest floor), the average vapor pressure deficit was about $371 \mathrm{~Pa}$ (Period 1) and $368 \mathrm{~Pa}$ (Period 2). The average temperature in the open-top chambers was $1-2{ }^{\circ} \mathrm{C}$ higher than on the forest floor, but showed no appreciable difference between the differently treated chambers. Because temperatures were generally higher inside the chambers than on the forest floor, the vapor pressure deficit of the chambers treated with ambient air were higher (498 $\mathrm{Pa}$ and $560 \mathrm{~Pa}$, respectively) than on the forest floor. In the chambers treated with reduced air, VPD was about $689 \mathrm{~Pa}$ and $833 \mathrm{~Pa}$, respectively. 
Table 1: Environmental parameters during the climate chamber experiment, and the open-top chamber experiment conducted on the forest floor. Given are daytime means of the different treatments and of the forest floor environment. Period $1=$ March $15-$ May 15,2005 (before leaf flushing of beech), period $2=$ May 15 - August 15, 2005 (after leaf flushing of beech). A, B, C = climate chamber treatments. a = outside the open-top chambers (herbaceous layer near the chambers), $b=$ ambient humidity treatment (inside the chambers), $c=$ reduced humidity treatment (inside the chambers). ${ }^{*}$ Mean values according to EGGERT (1985) and ERHARDT (1988).

\begin{tabular}{|c|c|c|c|}
\hline & \multirow[t]{2}{*}{ Climate chambers } & \multicolumn{2}{|l|}{ Open-top chambers } \\
\hline & & Period 1 & Period 2 \\
\hline $\mathrm{T}\left[{ }^{\circ} \mathrm{C}\right]$ & 20 & $a=10.2 ; b=11.3 ; c=11.4$ & $a=16.6, b=18.4 ; c=18.1$ \\
\hline $\mathrm{RH}[\%]$ & $A=85 ; B=60 ; C=40$ & $a=70 ; b=63 ; c=48$ & $a=83 ; b=77 ; c=63$ \\
\hline VPD $[\mathrm{Pa}]$ & $A=350 ; B=930 ; C=1400$ & $a=371 ; b=498 ; c=689$ & $a=368 ; b=560 ; c=833$ \\
\hline PAR $\left[\mu \mathrm{mol} \mathrm{m} \mathrm{m}^{-2} \mathrm{~s}^{-1}\right]$ & 142 & \multirow{2}{*}{\multicolumn{2}{|c|}{$\begin{array}{c}150^{*} \\
\text { soil water content near field capacity } \\
\text { natural forest soil }\end{array}$}} \\
\hline $\begin{array}{l}\text { water availability } \\
\text { nutrient availability }\end{array}$ & $\begin{array}{c}\text { hydroponic culture } \\
\text { nutrient solution culture }\end{array}$ & & \\
\hline
\end{tabular}




\section{Dry matter production, total leaf area, leaf size and number of leaves}

In the climate chamber experiment, dry matter production (whole plant) of both species was significantly larger at the lowest VPD level (treatment $A, V P D=350 \mathrm{~Pa}$ ) than at the highest VPD level $(C, V P D=1400 \mathrm{~Pa})$. In M. perennis, biomass production was more than $36 \%$ less in the driest treatment (VPD $=1400 \mathrm{~Pa}$ ) than in the moistest treatment $(\mathrm{VPD}=350 \mathrm{~Pa})$, while $S$. sylvatica showed a productivity reduction by about $42 \%$ in the dry treatment compared to the treatment with the most moisture (Fig. 2A). The results of the open-top chamber experiment on the forest floor confirmed the climate chamber data showing productivity reductions by about $25 \%$ in the treatment with reduced humidity (M. perennis: $28 \%$, S. sylvatica: $24 \%$. Fig. 2B).

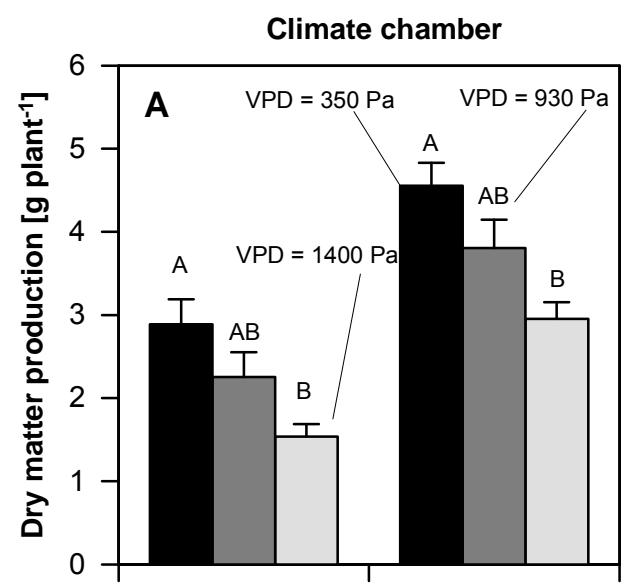

M.perennis

S.sylvatica

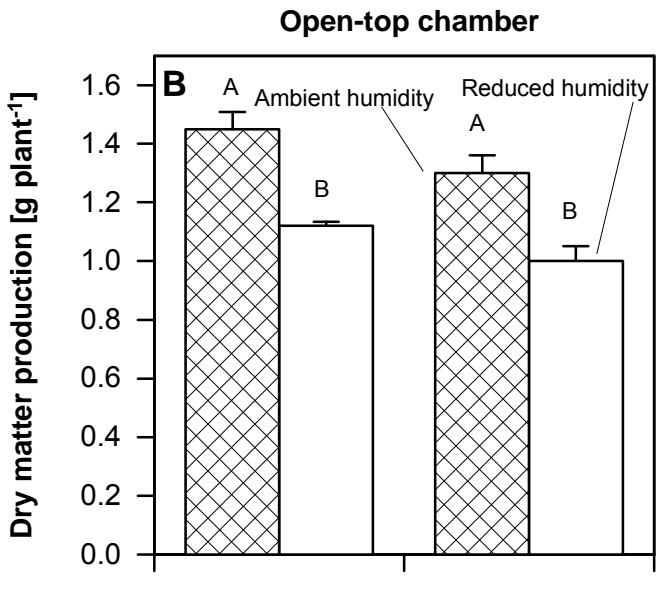

M.perennis

S.sylvatica

Fig. 2: Dry matter production of the two woodland herbs grown in the climate chamber $(A)$ and the open-top chamber (B) experiment. Means and standard errors of 12 (A) to 32 (B) plants per species and treatment are given. Significant $(P \leq 0.05)$ differences between the treatments are marked by different letters above the columns. Axes have different scales because of different plant growth rates in the two experiments which are primarily a consequence of different nutrient supplies (climate chamber experiment: nutrient solution; open-top chamber experiment: forest soil).

In the climate chamber experiment, the total leaf area of $M$. perennis plants decreased from the low to the high VPD level. The total leaf area of S. sylvatica showed no significant differences between treatment $A(V P D=350 \mathrm{~Pa})$ and treatment $B(V P D=$ $950 \mathrm{~Pa})$ but was reduced significantly in the driest treatment $(C, V P D=1400 \mathrm{~Pa})$, where it was about $40 \%$ less than in the moistest treatment (Fig. 3A). In the open-top chamber experiment, a similar tendency with a large and significant leaf area reduction in the reduced-humidity treatment of $S$. sylvatica was observed, while only a slight (non-significant) decrease occurred in M. perennis (Fig. 3B). 

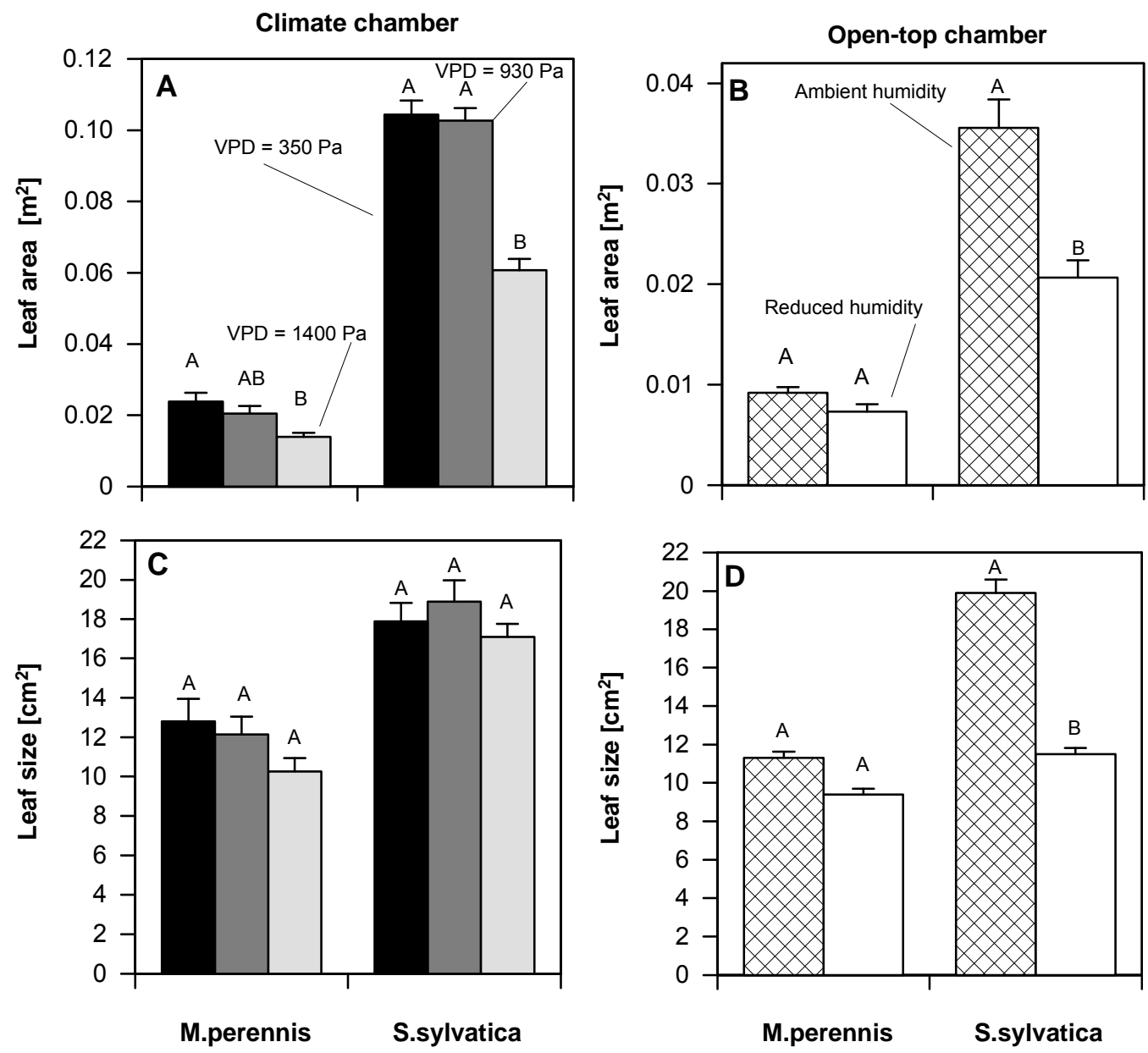

Fig. 3: Total leaf area per plant $(A$ and $B)$ and average leaf size $(C$ and $D)$ of the two woodland herbs grown in the climate chamber (left) and the open-top chamber (right) experiment. Means and standard errors of 12 (left) to 32 (right) plants per species and treatment are given. Significant $(P \leq 0.05)$ differences between the treatments are marked by different letters above the columns.

Average leaf size was not affected significantly by the prevailing VPD regime in either species in the climate chamber experiment (Fig. 3C). However, the total number of leaves per plant decreased with increasing VPD: in treatment $C(V P D=1400 \mathrm{~Pa})$, the leaf number of $M$. perennis was reduced by about $27 \%$ compared to treatment A (VPD $=350 \mathrm{~Pa})$; this reduction was even more striking in S. sylvatica $(40 \%$, Table 2). In the open-top chamber experiment on the forest floor, leaf size and leaf number of $M$. perennis showed no significant differences between the ambient and reduced humidity treatments, while leaf size of S. sylvatica was about $39 \%$ less in the dry air treatment (Fig. 3D). The number of established leaves showed no significant differences in this species (Table 2). 
Table 2: Number of leaves of the two woodland herbs grown in the climate chamber $(A)$ and the open-top chamber (B) experiment. Means and standard errors of 12 (A) to 32 (B) plants per species and treatment are given. Different letters indicate significant differences between the treatments $(P \leq 0.05)$.

\begin{tabular}{|c|c|c|}
\hline \multicolumn{3}{|c|}{ Number of leaves per plant } \\
\hline & M. perennis & S. sylvatica \\
\hline \multicolumn{3}{|l|}{ A Climate chamber } \\
\hline VPD = $350 \mathrm{~Pa}(\mathrm{~A})$ & $18.3( \pm 0.48)^{a}$ & $60.2( \pm 2.40)^{a}$ \\
\hline VPD = $930 \mathrm{~Pa}(\mathrm{~B})$ & $16.5( \pm 0.76)^{\mathrm{a}}$ & $55.3( \pm 2.29)^{\mathrm{a}}$ \\
\hline VPD = $1400 \mathrm{~Pa}(\mathrm{C})$ & $13.4( \pm 0.34)^{b}$ & $36.2( \pm 2.03)^{b}$ \\
\hline \multicolumn{3}{|l|}{ B Open-top chamber } \\
\hline ambient humidity & $8.07( \pm 0.20)^{a}$ & $18.5( \pm 1.05)^{\mathrm{a}}$ \\
\hline reduced humidity & $7.37( \pm 0.23)^{a}$ & $18.2( \pm 1.31)^{\mathrm{a}}$ \\
\hline
\end{tabular}

Leaf water turnover and water status

Leaf conductance for water vapor $\left(g_{\mathrm{L}}\right)$ measured in the $6^{\text {th }}$ and $7^{\text {th }}$ hour of the light period decreased in both species with an increase of the VPD regime in the climate chambers from 350 to $1400 \mathrm{~Pa}$. In Mercurialis perennis, leaf conductance in the dry treatment $(\mathrm{VPD}=1400 \mathrm{~Pa})$ reached on average only $56 \%$ of $\mathrm{g}_{\mathrm{L}}$ maintained in the moistest treatment (VPD = $350 \mathrm{~Pa}$, Table 3). Stachys sylvatica showed a decrease of $g_{\llcorner}$by about $26 \%$ in the dry treatment. Despite a decrease in average leaf conductance from 300 to $220 \mathrm{mmol} \mathrm{m}^{-2} \mathrm{~s}^{-1}$, the average transpiration rate increased in S. sylvatica from the moistest to the driest treatment with a VPD increase from 350 to $1400 \mathrm{~Pa}$ (Table 3). Mercurialis perennis had a lower leaf conductance and thus transpiration rate than S. sylvatica. This species reduced its average leaf conductance by about $45 \%$ with an increase in VPD level from 350 (treatment A) to $1400 \mathrm{~Pa}$ (treatment C). Leaf water potential $\Psi_{L}$ of the date of harvest decreased from - $0.28 \mathrm{MPa}$ (treatment A, $350 \mathrm{~Pa}$ ) to $-0.36 \mathrm{MPa}$ (treatment $\mathrm{C}, 1400 \mathrm{~Pa}$ ) in S. sylvatica, and from - 0.39 MPa (treatment $\mathrm{A}$ ) to $-0.48 \mathrm{MPa}$ in M. perennis. 
Table 3: Mean transpiration rate $\left(E_{L}\right)$, leaf conductance $\left(g_{L}\right)$ and leaf water potential $\left(\Psi_{L}\right)$ oft the two woodland herbs grown in the climate chamber experiment. Mean $\delta^{13} \mathrm{C}$ signature of leaf mass and shoot nitrogen concentration at the date of harvest of the two woodland herbs grown in the climate chamber (A), and the open-top chamber (B) experiment. Means and standard errors of 30-60 replicate measurements per species and treatment ( $\left.E_{L}, g_{L}\right), 6-$ 12 plants per species and treatment $\left(\Psi_{\mathrm{L}}\right)$ or $12(\mathrm{~A})$ to $32(\mathrm{~B})$ plants per species and treatment $\left(\delta^{13} \mathrm{C}, \mathrm{N}\right)$ are given. Different letters indicate significant differences between the treatments $(P \leq 0.05)$

\begin{tabular}{|c|c|c|c|c|c|c|}
\hline & & {$\left[\begin{array}{c}E_{L} \\
{\left[m m o l ~ m^{-2} s^{-1}\right]}\end{array}\right.$} & $\begin{array}{c}\mathrm{g}_{\mathrm{L}} \\
{\left[\mathrm{mmol} \mathrm{m} \mathrm{m}^{-2} \mathrm{~s}^{-1}\right]}\end{array}$ & $\begin{array}{c}\Psi_{\mathrm{L}} \\
{[\mathrm{MPa}]}\end{array}$ & $\begin{array}{c}\text { Leaf } \delta^{13} \mathrm{C} \\
{[\%]}\end{array}$ & $\begin{array}{c}\mathrm{N} \\
{\left[\mathrm{mmol} \mathrm{g}^{-1}\right]}\end{array}$ \\
\hline \multicolumn{7}{|c|}{ A Climate chamber } \\
\hline \multirow[t]{3}{*}{ M. perennis } & VPD $=350 \mathrm{~Pa}$ & $0.83( \pm 0.05)^{a}$ & $134( \pm 2.81)^{a}$ & $-0,39( \pm 0.03)^{a}$ & $-32.3( \pm 0.16)^{a}$ & $2.85( \pm 0.77)^{a}$ \\
\hline & VPD = $930 \mathrm{~Pa}$ & $0.87( \pm 0.06)^{a}$ & $117( \pm 3.32)^{a}$ & $-0.44( \pm 0.02)^{a b}$ & $-32.1( \pm 0.28)^{a}$ & $3.58( \pm 0.76)^{b}$ \\
\hline & VPD $=1400 \mathrm{~Pa}$ & $0.96( \pm 0.08)^{b}$ & $75( \pm 3.33)^{b}$ & $-0.48( \pm 0.02)^{b}$ & $-29.1( \pm 0.19)^{b}$ & $3.67( \pm 0.51)^{b}$ \\
\hline \multirow[t]{3}{*}{ S. sylvatica } & VPD = $350 \mathrm{~Pa}$ & $2.01( \pm 0.05)^{a}$ & $302( \pm 5.81)^{a}$ & $-0.28( \pm 0.01)^{a}$ & $-32.3( \pm 0.27)^{a}$ & $4.34( \pm 0.32)^{a}$ \\
\hline & VPD $=930 \mathrm{~Pa}$ & $2.77( \pm 0.10)^{b}$ & $280( \pm 8.94)^{a}$ & $-0.31( \pm 0.02)^{\mathrm{ab}}$ & $-32.8( \pm 0.15)^{a}$ & $4.56( \pm 0.42)^{a}$ \\
\hline & VPD $=1400 \mathrm{~Pa}$ & $2.99( \pm 0.08)^{b}$ & $225( \pm 7.32)^{\mathrm{b}}$ & $-0.36( \pm 0.02)^{b}$ & $-31.7( \pm 0,63)^{a}$ & $4.28( \pm 0.34)^{\mathrm{a}}$ \\
\hline \multicolumn{7}{|c|}{ B Open-top chamber } \\
\hline \multirow[t]{2}{*}{ M. perennis } & ambient humidity & n.d. & n.d. & n.d. & $-28.4( \pm 0.31)^{a}$ & $3.34( \pm 0.35)^{a}$ \\
\hline & reduced humidity & n.d. & n.d. & n.d. & $-28.2( \pm 0.12)^{a}$ & $3.27( \pm 0.07)^{a}$ \\
\hline \multirow[t]{2}{*}{ S. sylvatica } & ambient humidity & n.d. & n.d. & n.d. & $-32.9( \pm 0.18)^{a}$ & $3.85( \pm 0.10)^{a}$ \\
\hline & reduced humidity & n.d. & n.d. & n.d. & $-32.4( \pm 0.11)^{a}$ & $3.85( \pm 0.26)^{a}$ \\
\hline
\end{tabular}


The $\delta^{13} \mathrm{C}$ signature in the mass of leaves harvested after 60 or 80 days of cultivation in the climate chambers was significantly less negative in treatment C (VPD $=1400 \mathrm{~Pa}$ ) for M. perennis plants and tended to be so in S. sylvatica plants in comparison to the moistest treatment. In the open-top chamber experiment on the forest floor, reduced air humidity led to no significant changes of foliar $\delta^{13} \mathrm{C}$ (Table 3). In M. perennis, shoot concentrations of $\mathrm{N}$ decreased in the climate chamber experiment with an increase of VPD but showed no differences between the treatments in the open-top chamber experiment. In S. sylvatica, different humidity regimes had no effect on foliar $\mathrm{N}$ concentrations in either of the experiments (Table 3).

\section{Discussion}

By linking a climate chamber to a field manipulation study, this investigation is the first to show unambiguously that the prevailing VPD level acts as an independent factor for growth and development of wild plants. Although it has often been assumed that air humidity plays an important role for plant growth and morphogenesis in shaded habitats such as ravines or north-facing crevices, no rigorous experimental test exists which distinguishes between atmospheric and soil water status effects.

Any discussion of VPD effects on plant physiology and growth has to distinguish carefully between short-term and long-term effects. The former include the control of transpiration by the leaf-to-air vapor pressure difference and the VPD-sensitivity of stomata observed in many plant species (e.g., LANGE et al. 1971, FARQUHAR 1978, TURNER et al. 1985, GRANTZ 1990, GRANTZ \& MEINZER 1990, APHALO \& JARVIS 1991, MOTT \& PARKHURST 1991, BEYSCHLAG et al. 1992, COWAN 1994, SCHULZE 1994, MONTEITH 1995, BUNCE 1997, FRANKS et al. 1997, MAROCO et al. 1997, BUNCE 2006). Much less is known about long-term effects of contrasting VPD levels on plant morphogenesis and productivity. Given that plants are integral elements of the soilplant-atmosphere continuum with plant water status depending on both soil water and atmospheric water status, our currently limited understanding of the effects of air humidity on plant growth is unsatisfactory.

The results of the climate chamber and open-top chamber experiment with two typical hygromorphic temperate woodland herbs showed a significant reduction in dry matter production of plants grown under elevated VPD and ample soil moisture availability. After 60 to 80 days of cultivation, productivity (above- and below-ground) of Mercurialis perennis and Stachys sylvatica decreased by $36 \%$ to $42 \%$ in the climate chamber experiment upon a reduction in the air humidity level from $85 \%$ to $40 \%$ of relative 
humidity (equivalent to a VPD increase by about $75 \%$ ), and by about $25 \%$ upon a reduction in relative air humidity by approximately $15 \%$ in the open-top chamber experiment on the forest floor.

The forest floor environment of Central European deciduous forests is characterized by the nearly permanent exposure to low VPD levels. For example, KRIEBITZSCH et al. (1985) conducted continuous microclimate measurements on the forest floor of the Göttinger Wald beech forest of this study and obtained typical daytime means of VPD of 200 to $600 \mathrm{~Pa}$ in the period March to June. In the field experiment of this study, the saturation deficit was recorded with an air humidity sensor in the herbaceous layer close to the open-top chambers; daytime means were about $371 \mathrm{~Pa}$ in the period before leaf-flushing of beech (March 15 to May 15, 2005), and $368 \mathrm{~Pa}$ in the season after leaf flushing (May 15 to August 15, Table 1). These conditions were simulated in the moistest treatment of the climate chamber treatment $(\mathrm{A}, 350 \mathrm{~Pa})$, and were approximated in the control of the open-top chamber treatment (498/560 Pa). Higher VPD levels exceeding 600 or even $1000 \mathrm{~Pa}$ occur on the forest floor of Central European beech forests only during short periods when light flecks hit the ground or during extended summer droughts (EHRHARDT 1988). Gaps created by natural tree fall or by clear-cut may expose woodland herbs permanently to saturation deficits of 1000 to $2000 \mathrm{~Pa}$. Treatment B (VPD = $930 \mathrm{~Pa}$ ) of our climate chamber experiment and the reduced-humidity treatment of the open-top chamber experiment (689/833 Pa) simulated a slight increase in the saturation deficit level as may occur with minor changes in the canopy closure of the forest, while treatment $\mathrm{C}$ of the climate chamber experiment $(\mathrm{VPD}=1400 \mathrm{~Pa}$ ) exposed the woodland herbs to a climate which is characteristic for open, non-woody vegetation types such as temperate grasslands or heathlands. For example, daytime VPD averaged at $750 \mathrm{~Pa}$ to $1500 \mathrm{~Pa}$ in meadows and heathlands of Central Germany during summer (LEUSCHNER, unpublished results).

Not surprisingly, the biomass reduction was more pronounced with a VPD increase from 350 to $1400 \mathrm{~Pa}$ in the climate chamber experiment than in the open-top chamber experiment where saturation deficit increased only by about $33 \%$ from 498/560 to $689 / 833 \mathrm{~Pa}$. The contrasting growth conditions in the two experiments with optimal water and nutrient supply only in the climate chamber experiment may also have contributed to the more pronounced VPD effect on growth in this trial. Because I used realistic VPD, light and temperature regimes and included an experiment which manipulated the environment in the forest in situ, this study provided convincing 
evidence of an important soil-water independent effect of air humidity on the growth and morphogenesis of temperate woodland herbs.

My data from woodland herbs is in accordance with results from crop and ornamental plants that were grown at different VPD levels for extended periods. The large majority of these agricultural and horticultural studies found a decrease in growth rate by $40 \%$ to $90 \%$ when VPD was increased from low to medium or high levels (NIGHTINGALE \& MITCHELL 1934, WENT 1957, HOFFMAN et al. 1971, KRIZEK et al. 1971, FORD \& THORNE 1974, TibbitTs \& Bottenberg 1976, WoodWARd \& Begg 1976, Hoffman \& Jobes 1978, HUNTER et al. 1985, SALIM 1989, GISLERÖD \& MORTENSEN 1990, MORTENSEN \& GISLERÖD 2000). High air humidities stimulated both herbaceous crop species and young fruit trees (TROMP \& OELE 1972). On the other hand, a limited number of studies found no influence of VPD on productivity (O'LEARY \& KNECHT 1971, FORD \& THORNE 1974 , HOFFMAN \& JOBES 1978), or a decrease at very high air humidity (WINNEBERGER 1958).

In both experiments of the present study, the reduction in biomass in the drier treatments was closely associated with a reduced total leaf area. In the climate chamber experiment, leaf area reduction was mainly due to a smaller number of leaves produced in the drier treatments, while average leaf size was not significantly altered. In contrast, reduced atmospheric moisture led to a smaller average leaf size in the open-top chamber experiment, while leaf number remained unchanged. Thus, the results of this study produce evidence that elevated VPD levels can have a negative influence on both the initiation of leaf buds and on leaf extension, the two processes that determine leaf area development in plants.

Several causal chains between atmospheric water status and plant growth are possible which could explain the significant growth-reducing effect of high VPD levels. First, elevated VPD could negatively influence leaf growth through a higher transpirative water loss and a lowered turgor in the growing leaf, thus reducing division or elongation of the meristematic cells (leaf growth limitation hypothesis). Second, elevated VPD could induce partial stomatal closure, thereby limiting carbon assimilation (reduced carbon gain hypothesis). Although a deeper analysis of the physiological causes of the growth reduction was beyond the scope of this study, this investigation provided some evidence in support of the leaf growth limitation hypothesis. Leaf water potential, measured in the $3^{\text {rd }}$ and $4^{\text {th }} \mathrm{hr}$ of the light period on the date of harvest, significantly decreased by $0.08-0.09 \mathrm{MPa}$ in $\mathrm{M}$. perennis and S. sylvatica plants when the VPD level was lowered from 350 to $1400 \mathrm{~Pa}$ in the climate chamber experiment (Table 3). Direct 
soil water-independent effects of atmospheric water status on leaf turgor and leaf growth, as indicated in this study, have also been reported in studies with other dicots (FRENSCH 1997, SERPE \& MATTHEWS 2000). In fact, even small reductions of leaf turgor or leaf water potential have been found to reduce leaf expansion significantly (ACEVEDO et al. 1971, DALE 1988, HSIAO et al. 1998), either through a hydraulic effect on cell elongation rate (WestGate \& BOYER 1985, KRAMER 1988, GoWING et al. 1990, PASSIOURA \& FREY 1992, PASSIOURA 1994, FRENSCH 1997, HSIAO et al. 1998, MUNNS et al. 2000, SERPE \& MATTHEWS 2000), or a negative effect of abscisic acid (ABA) on leaf growth (ZHANG \& DAVIES 1990 a,b, DODD \& DAVIES 1996, AlVES \& SETTER 2000).

The results of this study provided no unequivocal evidence in supporting the reduced carbon gain hypothesis. While average leaf conductance in the $6^{\text {th }}$ and $7^{\text {th }} \mathrm{hr}$ of the light period was significantly smaller in the $1400 \mathrm{~Pa}$ than in the $350 \mathrm{~Pa}$ treatment of the climate chamber experiment in both species (Table 3), light-saturated net photosynthesis rate was not reduced in the plants of the dry-air treatment (LENDZION, unpublished results). Moreover, the reduction in leaf area in the dry-air treatment was as large as the reduction in dry matter produced, or even exceeded it, in the climate chamber experiment and the open-top chamber experiment. This indicates that the reduction in leaf conductance had only a small or no effect on the rate of carbon assimilation in the dry-air treatment.

A more detailed analysis of the components of leaf elongation rate, leaf photosynthetic activity and leaf ABA levels is needed to understand the causes of plant growth reduction under elevated VPD levels. Such a causal analysis must also address indirect effects of atmospheric moisture on plant growth, for example, through altered foliar nutrient levels. 


\section{Chapter 4}

Growth of European beech (Fagus sylvatica L.) saplings is limited by elevated atmospheric vapor pressure deficits

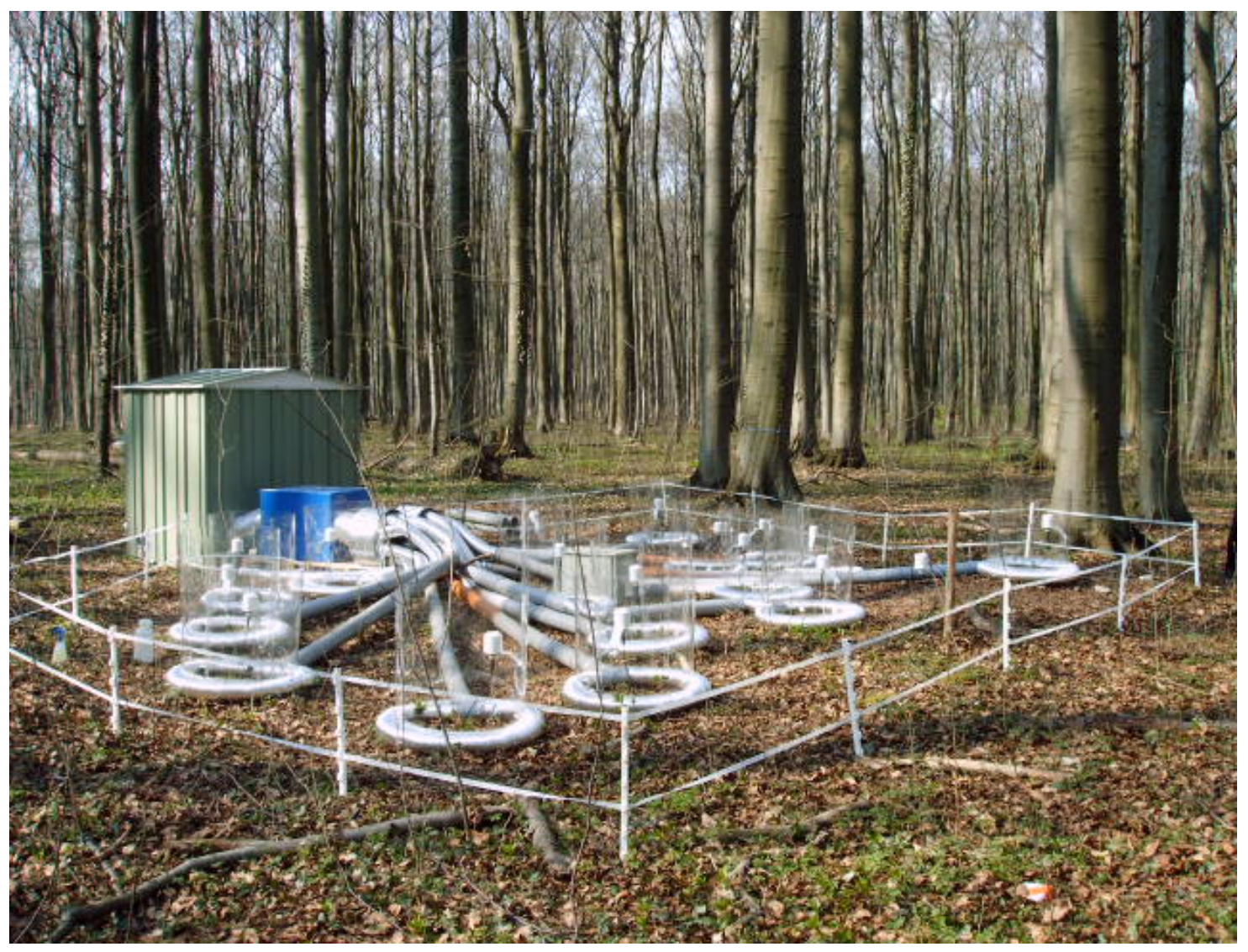




\begin{abstract}
There is an ongoing debate about how European beech might be affected by a future drier climate. While numerous studies have examined the effects of soil drought on beech growth and development, there is a lack of investigations with a focus on the effects of lowered air humidity. I tested the hypothesis that reduced air humidity negatively affects the growth and development of beech saplings by reducing air humidity in a climate chamber experiment, and in an open-top chamber experiment on the forest floor while soil moisture remained optimal. In the climate chamber experiment, productivity decreased by about $68 \%$ with an air humidity reduction of $45 \%$. In the open-top chamber experiment, biomass production declined by about $30 \%$ when air humidity was reduced by about $15 \%$. The reduction in biomass was mainly a consequence of reduced leaf growth, which was dramatically reduced in the reduced humidity treatments. The results of my study show that the growth and development of beech saplings strongly depends not only on soil moisture but also on the prevailing air humidity level. Air humidity is a widely ignored factor which influences growth and vitality, and possibly also the distribution of European beech. Therefore, future forest management schemes under an altered climate should take this factor into account.
\end{abstract}




\section{Introduction}

Drought is a key factor limiting tree growth not only in arid but often also in humid climates (GOWER et al. 1992, BECKER et al. 1994). When soil water is depleted, a number of tree functions are inhibited. The ability of trees to function under drought stress depends on various physiological and morphological traits, among the most important the capacity of the roots to guarantee water uptake in drying soils, and the ability to continue leaf growth during drought (KOZLOWSKI \& PALLARDY 1997, SAXE et al. 1998). The maintenance of leaf area is crucial for tree vitality because light interception, carbon assimilation and transpiration are closely linked to canopy surface area. With respect to its natural abundance European beech (Fagus sylvatica L.) is the most important broad-leaved tree species in Central and Western Europe, which dominated forests on moderately dry to moist soils in this area prior to human intervention. It was replaced by more drought-tolerant species such as Quercus petraea (Mattuschka) Liebl. or Q. pubescens Willd. only in drier environments. Beech is known for its drought sensitivity (ELLENBERG 1996, BACKES \& LEUSCHNER 2000) which is a key factor limiting its distribution range in Southern and Southeastern Europe (HORVAT et al. 1974). In climate chamber and garden experiments, and in transect studies, it has been found that water shortage reduces beech canopy conductance (GRANIER et al. 2000, GESSLER 2004, SCHIPKA et al. 2005), photosynthetic activity (TERBORG 1998), leaf water potential (TOGNETTI et al. 1995, BACKES \& LEUSCHNER 2000), diameter increment (BECKER et al. 1994, SCHIPKA et al. 2005), and height growth (BRAUN \& FLÜCKIGER 1987, FRECH 2006). Nearly all of these studies focused on the effect of limited soil moisture while the consequences of reduced air humidity levels were not investigated. This is surprising because air humidity, or the water vapor saturation deficit of the air (VPD), has been found to have a significant and often large influence on plant growth and development of crop, horticultural plants and wild plants (e.g., HOFFmAN et al. 1971, Ford \& THORNE 1974, Hoffman \& Jobes 1978, TibBits 1979, GRANGe \& HAND 1987, GisleRÖd \& MoRTENSEN 1990, MARSDEN et al. 1996, MORTENSEN \& GISLERÖD 2000, ROBERTS \& ZWIAZEK 2001, LEUSCHNER 2002, CODARIN et al. 2006).

In the light of climate change, it has been suggested that the growth and competitive ability of beech will be strongly affected by increased drought periods during the growing season (GESSLER et al. 2001, FOTELLI et al. 2003, GESSLER et al. 2007). It has been assumed that even though beech may withstand moderate droughts, it is likely that this species will suffer from summer droughts of extended length and higher frequencies (GESSLER et al. 2001). Decreases in summer rainfall and increases in 
temperature should also rise the VPD, a factor that may increase drought stress in beech. Unfortunately, the role of VPD in controlling growth and distribution of beech has not been investigated so far. This weakens any predictions of how European beech will respond to a drier and warmer climate in the coming decades.

This study examines long-term effects of different air humidity levels on the physiology and productivity of beech saplings. Defined humidity levels in the sapling environment were achieved by manipulating atmospheric moisture both in a climate chamber experiment and a field experiment on the forest floor. A recently developed open-top chamber technique was used for manipulating air humidity in the natural environment of the beech saplings on the forest floor. The hypothesis tested, should prove that reduced air humidity, acting independently from soil moisture, negatively affects productivity and represents a stress factor for the physiology of beech saplings. It is expected that atmospheric drought (elevated VPD) will affect negatively growth and development of beech saplings in a similar manner as soil drought does.

\section{Material and methods}

\section{Plant material}

Seeds of Fagus sylvatica L. were collected in autumn 2004 in the woodlands of the surroundings of Göttingen (Lower Saxony, Central Germany). The seeds were placed in moist sand and kept at a constant temperature of $5{ }^{\circ} \mathrm{C}$. After four weeks, the seeds were transferred to a glasshouse with a constant temperature of $20{ }^{\circ} \mathrm{C}$. After germination, the seedlings were grown for about ten weeks in moist sand at quantum flux densities of $200 \mu \mathrm{mol}$ photons $\mathrm{m}^{-2} \mathrm{~s}^{-1}\left(20^{\circ} \mathrm{C}\right.$, VPD $\left.=500-800 \mathrm{~Pa}\right)$. When the plants were 70 days old and about $10 \mathrm{~cm}$ high, they were transferred either to the climate chambers (April to July 2005) or to the open-top chambers in the field (August 2005 to August 2006).

\section{Climate chamber experiment}

The climate chamber experiment was undertaken from April to July 2005. To guarantee a non-limiting soil moisture and nutrient supply regime the saplings were cultivated in pots that contained $1500 \mathrm{~cm}^{3}$ nutrient solution (one sapling per pot). Complete $0.2 x$ Shive solutions (BAUMEISTER \& ERNST 1978) were added once a week to prevent any nutrient limitation during the experiment. Every two or three days, the $\mathrm{pH}$ of the solution was adjusted to a value of 4.5. The ionic concentration of the solution was 
approximately 4 mosmol L $\mathrm{L}^{-1}$ which relates to a water potential of $-0.009 \mathrm{MPa}$. To avoid oxygen limitation, the solutions were constantly ventilated with compressed air.

The beech saplings were grown for a period of three months in the climate chambers (BBC, Brown Boveri-York, Hamburg, Germany) at constant vapor pressure deficits of 350 (treatment A), $930(B)$ and $1400 \mathrm{~Pa}(\mathrm{C})$ in the 14-hour light phase, and of 250, 712 and $1068 \mathrm{~Pa}$ in the 10 -hour dark phase. This relates to a relative air humidity of $85 \%$, $60 \%$ and $40 \%$ in the treatments $A, B$ and $C$, respectively. The air temperature during the light phase was $20( \pm 1){ }^{\circ} \mathrm{C}$, and $15( \pm 1){ }^{\circ} \mathrm{C}$ during the dark phase. Thermohygrographs were used to control air humidity in each chamber. Fluora lamps (Osram Inc.) provided a constant quantum flux density of $142( \pm 10) \mu \mathrm{mol} \mathrm{m} \mathrm{m}^{-2} \mathrm{~s}^{-1}$ during the light phase in order to simulate realistic below-canopy light regimes (Table 1). Earlier measurements with quantum sensors on the forest floor of Central German beech forests reported a quantum flux density of 100 to $200 \mu \mathrm{mol} \mathrm{m}-2 \mathrm{~s}^{-1}$ before leaf flushing of beech, and of 10 to $15 \mu \mathrm{mol} \mathrm{m}-2 \mathrm{~s}^{-1}$ after leaf development.

\section{Open-top chamber experiment}

For simulating a drier climate on the forest floor with elevated VPD but with otherwise unchanged environmental conditions, an open-top chamber system was designed that allowed a manipulation of the air humidity on the forest floor in situ. The system consisted of eight circular open-top chambers and was in its principal design similar to those open-top chamber systems that are used for $\mathrm{CO}_{2}$ - manipulation experiments in grasslands (e.g., HÄTTENSCHWILER \& KÖRNER 2000, HolLister \& WebBER 2000). The open-top chambers were established for one year (August 2005 to August 2006) on the forest floor of the Göttinger Wald beech forest east of Göttingen ( $\left.51^{\circ} 32^{`} \mathrm{~N}, 10^{\circ} 03^{`} \mathrm{E}\right)$. The chambers were made of 2-mm-thick UV-transmissive plexiglass with a diameter of $65 \mathrm{~cm}$ and a height of $60 \mathrm{~cm}$. The eight chambers were positioned randomly on the forest floor. Four of the chambers were treated with ambient air (control) and four with air of reduced water vapor content.

In order to produce a steady air flow through the chambers, one large radial fan was installed for the four chambers of each treatment. The air flow was adjusted in all eight chambers to a mean of $0.5 \mathrm{~m} \mathrm{~s}^{-1}$ and was continuously controlled. This procedure guaranteed a complete turnover of the air inside the chambers every 30 seconds. For reducing air humidity, two absorption air driers (Resuscorb, DST Seibu Giken, Sweden) were used that decreased air humidity constantly by up to $15 \%$ compared to the control chambers. Plastic pipes with access to the bottom of each chamber were used to 
channel the air into all eight open-top chambers. Humidity manipulation was conducted in both growing seasons covered by the experiment, i.e. from August to October 2005 and from May to July 2006, when harvest took place. No air humidity control occurred in the winter months (November 2005 to April 2006). Air humidity and air temperature were continuously recorded inside and outside the chambers (on the forest floor) with capacitive air humidity sensors (Hygroclip, Rotronic AG, Ettlingen, Germany). The data was logged every $15 \mathrm{~s}$ with a Campbell logger (Campbell, Logan, USA).

In order to avoid air temperature differences between the treatments, a cross-flow heat exchanger (Duplexvent 15000, Airflow Lufttechnik $\mathrm{GmbH}$, Rheinbach, Germany) was used to match the air temperature of the dried and ambient air stream. During the growing season, the soil moisture in the chambers was monitored two times a week with a mobile TDR probe (trime, Imko, Ettlingen, Germany). Earlier measurements of BENECKE (1982) showed that the field capacity for water in this soil is about $45 \mathrm{vol} \%$. In order to guarantee that no significant differences in soil moisture existed between the chambers, and to avoid any soil water limitation during the experiment, small amounts of water were applied when the soil moisture in the chambers deviated from a target value of 40 vol\%. In each chamber, seven beech saplings were planted inside a fence that protected the roots and the shoots from rodent damage.

\section{Determination of dry matter production and leaf development}

The beech saplings were harvested after 90 (climate chamber experiment) or 360 days (open-top chamber experiment). The plant material was separated into above- and below-ground organs, oven-dried $\left(72 \mathrm{~h}, 70^{\circ} \mathrm{C}\right)$ and weighed. The number of replicate plants in a treatment was 12 in the climate chamber experiment and 28 in the open-top chamber experiment (4 chambers per treatment with 7 plants each). The four chambers of each treatment were treated as a sample for further statistical analysis. The dry matter production of the saplings was calculated from the difference in mass at the beginning and the end of the experiment. The dry weight at the beginning of the experiment was determined from a random sample of 10 beech saplings that were harvested at the first day of the experiment. To obtain total dry matter production I added above- and below-ground biomass. The program Win Folia 5.1 a (Régent Instruments Inc., Quebec, Canada) was used to determine the total leaf area and average leaf size of each plant. Additionally, the number of established leaves and leaf buds were counted. 


\section{Determination of leaf water status parameters}

In the climate chamber experiment, the following parameters were measured on different occasions to determine changes in leaf water status and leaf water turnover: Leaf water potential $\left(\Psi_{\mathrm{L}}\right)$ was measured on three occasions during the experiment using the pressure chamber technique (SCHOLANDER et al. 1965). Measurements were conducted in the third and fourth hour of the light period on fully developed leaves of highest or second- highest insertion (6 replications on different plants per treatment and occasion). Pressure-volume curves were generated on three occasions during the experiment using the over-pressurization technique in a pressure chamber (TYREE \& JARVIS 1982). On each occasion, six individual leaves or shoots with two leaves per treatment were analyzed to determine leaf turgor and osmotic potentials at full turgor $\left(\Pi_{100}\right)$ and at zero turgor $\left(\Pi_{0}\right)$. Leaves or shoots were collected in the evening at about $7 \mathrm{pm}$, recut under water, and hydrated to near maximum turgor pressure during the night. Pressure-volume curves were established on leaves or shoots that were cleaned from adherent water and remained enclosed in plastic bags to prevent transpiration. The pressure in the chamber was increased in steps of about $0.3 \mathrm{MPa}$ and the expressed sap was collected in small vials filled with tissue paper. Leaf turgor was estimated by relating the actual water potential data (measured during the third and fourth hour of the light period) to the related pressure-volume curve after subtracting the corresponding $\Pi$ values. Pressure-volume curve analysis was only conducted in the treatments $\mathrm{A}$ and $\mathrm{C}$ of the climate chamber experiment.

On six occasions during the experiment, leaf conductance $\left(\mathrm{g}_{\mathrm{L}}\right)$ and leaf transpiration $\left(E_{L}\right)$ were measured. The measurements were taken during the sixth and seventh hour of the light period with a steady-state porometer (LI-1600, LiCor Inc., Lincoln, NE, USA) and were conducted at the abaxial surface of 10-15 fully developed leaves of the highest or second-highest insertion per treatment. Since the capacitive sensor of the porometer is known to give unreliable VPD readings at high air humidity levels, the conductance values in the treatment $A$ with high air humidity (VPD $=350 \mathrm{~Pa}$ ) were corrected by comparing them with independent psychrometer data: At the beginning of a measuring day, in each chamber two or three hygrometric measurements were conducted in each chamber at plant height and the values were then compared with the readings of the capacitive humidity sensor. They were used for correction if deviations were observed. 


\section{Statistical analysis}

The program SAS 8.2 (SAS Institute, Cary, NC, USA) was used for all statistical analysis. A Shapiro and Wilk test was used to test the data for normal distribution. In case of normal distribution, a Scheffé test was used to detect significant differences between means; a Wilcoxon-U-test was used for non-normally distributed data. Significance was determined at $P \leq 0.05$.

\section{Results}

\section{Environmental parameters inside and outside the open-top chambers}

On the forest floor outside the open-top chambers, the mean vapor pressure deficit of the growing season (May, 1 to October, 1) was $410 \mathrm{~Pa}$ (Table 1). The mean temperature in the open-top chambers was on average $1-2{ }^{\circ} \mathrm{C}$ higher than outsite the chambers, but showed only $0.4{ }^{\circ} \mathrm{C}$ difference between the two chamber treatments. Because temperatures were somewhat higher in the chambers than on the forest floor (outside the chambers), the vapor pressure deficit in the control chambers treated with ambient air was also higher than on the forest floor (582 vs. $410 \mathrm{~Pa}$ ). Mean VPD of the reduced humidity chambers was $815 \mathrm{~Pa}$ in the growing season (Table 1).

Table 1: Environmental parameters during the climate chamber experiment, and the open-top chamber experiment on the forest floor. Given are daytime means of the different climate chamber treatments $(A, B, C)$ and of the forest floor environment: $a=$ outside the open-top chambers (herbaceous layer near the chambers), $b=$ ambient humidity (inside the chambers, control), $c=$ reduced humidity (inside the chambers). ${ }^{*}$ Mean value according to Eggert (1985) and Erhardt (1988).

\begin{tabular}{|c|c|c|c|c|c|c|}
\hline & \multicolumn{3}{|c|}{ Climate chambers } & \multicolumn{3}{|c|}{ Open-top chambers } \\
\hline & A & B & C & $\mathbf{a}$ & $\mathbf{b}$ & c \\
\hline VPD [Pa] & 350 & 930 & 1400 & 410 & 582 & 815 \\
\hline Relative humidity [\%] & 85 & 60 & 40 & 76 & 69 & 55 \\
\hline Air temperature $\left[{ }^{\circ} \mathrm{C}\right]$ & 20 & 20 & 20 & 13 & 14 & 14 \\
\hline PAR $\left[\mu \mathrm{mol} \mathrm{m} \mathrm{m}^{-2} \mathrm{~s}^{-1}\right]$ & \multicolumn{3}{|c|}{142} & \multicolumn{3}{|c|}{$150^{*}$} \\
\hline soil water regime & \multicolumn{3}{|c|}{ hydroponic culture } & \multicolumn{3}{|c|}{$\begin{array}{l}\text { soil water content near field } \\
\text { capacity }\end{array}$} \\
\hline nutrient supply & \multicolumn{3}{|c|}{ nutrient solution } & \multicolumn{3}{|c|}{ natural forest soil } \\
\hline
\end{tabular}

\section{Dry matter production and leaf development}

In the climate chamber experiment, the biomass production of the beech saplings was significantly reduced when the VPD level increased from 350 to $1400 \mathrm{~Pa}$ (Fig. 1A). In 
the driest treatment (treatment C, VPD $=1400$ ), a productivity reduction by about $68 \%$ was observed in comparison to the moistest treatment $(A, V P D=350 \mathrm{~Pa})$. This result was supported in the open-top chamber experiment on the forest floor where dry matter production declined by about $30 \%$ in the reduced humidity treatment (Fig.1B).
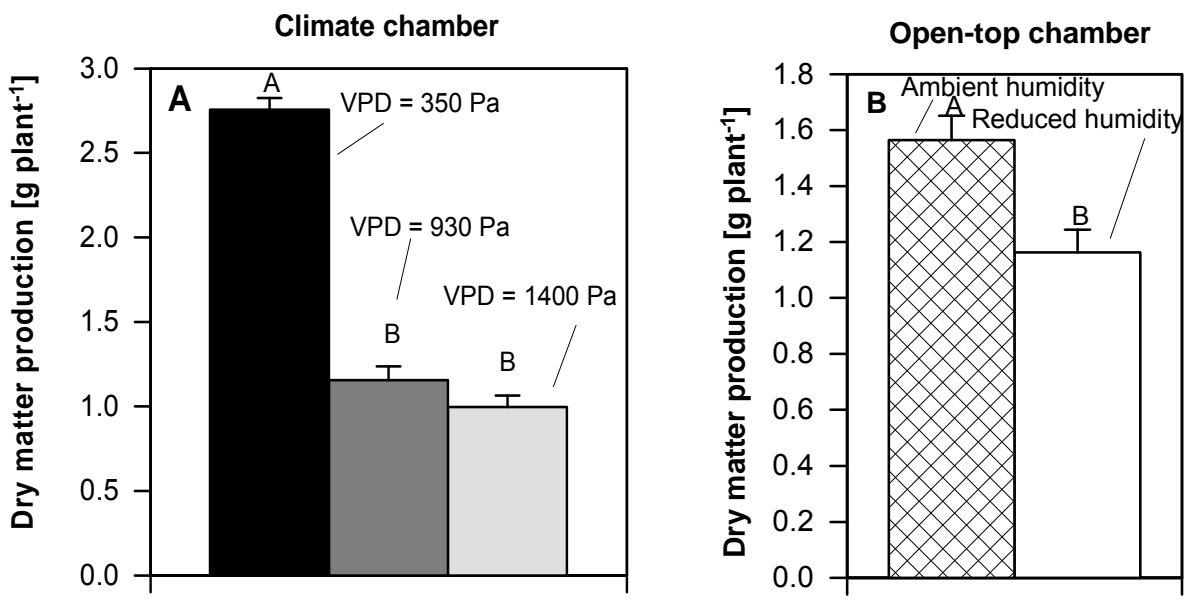

Fig. 1: Dry matter production of the beech saplings grown in the climate chamber $(A)$ and the open-top chamber (B) experiment. Means and standard errors of 12 (A) to 28 (B) plants per treatment are given. Significant $(P \leq 0.05)$ differences between the treatments are marked by different letters above the columns. Axes have different scales because of different plant growth rates in the two experiments which are primarily a consequence of different nutrient supply rates (climate chamber experiment: nutrient solution; open-top chamber experiment: forest soil).

The total leaf area of the beech saplings declined by about $79 \%$ in the climate chamber experiment when VPD was increased from $350 \mathrm{~Pa}$ to $1400 \mathrm{~Pa}$ (Fig. 2A). The average leaf size of the beech saplings was reduced significantly between treatment $A$ (VPD = $350 \mathrm{~Pa})$ and $\mathrm{B}(\mathrm{VPD}=930 \mathrm{~Pa})$ but there was no significant difference between treatment $\mathrm{B}(\mathrm{VPD}=930 \mathrm{~Pa})$ and $\mathrm{C}(\mathrm{VPD}=1400 \mathrm{~Pa})$. 

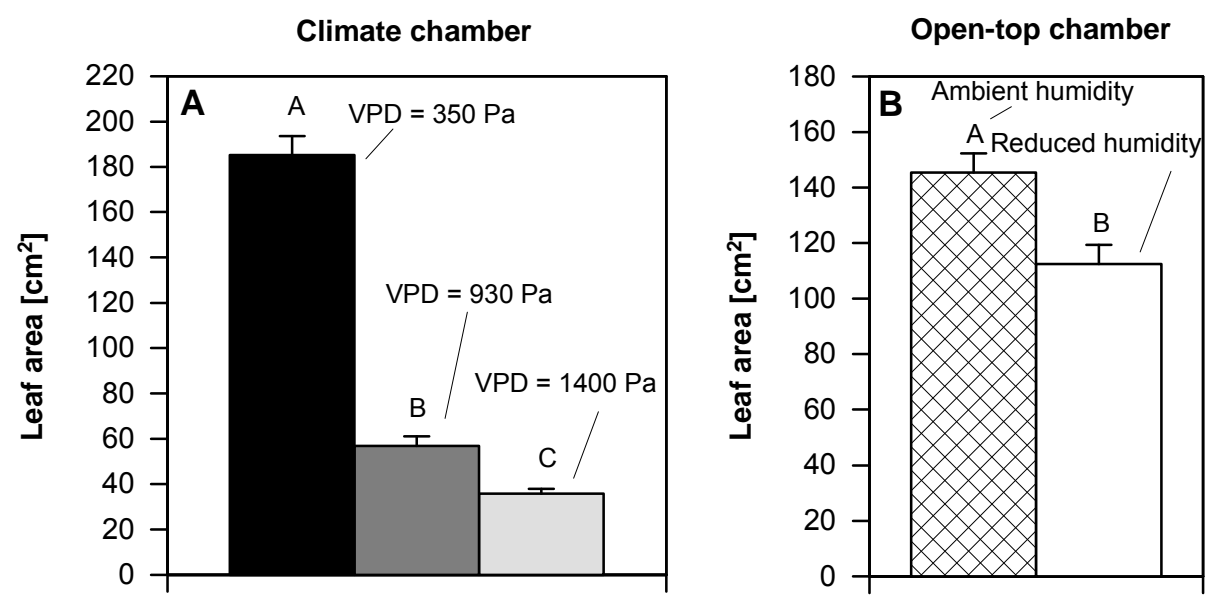

Fig. 2: Total leaf area of the beech saplings grown in the climate chamber $(A)$ and the open-top chamber (B) experiment. Means and standard errors of 12 (A) to 28 (B) plants per treatment are given. Significant $(P \leq 0.05)$ differences between the treatments are marked by different letters above the columns. Note different scale of $y$-axes.

Moreover, the number of leaves and buds declined with increasing VPD level (Table 2).

With a decrease from 12 leaves per plant, on average, in the moistest treatment (VPD $=350 \mathrm{~Pa}$ ) to only three leaves in the driest treatment $(\mathrm{VPD}=1400 \mathrm{~Pa})$, the reduction was very large. Additionally, in the driest treatment, nearly all buds died and no new leaves were expanded during the experiment. Leaf development was also negatively affected by reduced air humidity in the open-top chamber experiment as well. In this experiment, total leaf area was lowered by about $23 \%$ in the reduced humidity treatment (Fig. 2B). In contrast to the climate chamber experiment, average leaf size was not affected significantly by reduced air humidity in the open-top chamber experiment, but the number of leaves and buds declined significantly under elevated VPD (Table 2). 
Table 2: Average leaf size, number of leaves, and number of leaf buds of the beech saplings grown in the climate chamber and the open-top chamber experiment. Means and standard errors of 12 and 28 plants per treatment are given for the two experiments, respectively. Different letters indicate significant differences between the treatments $(P \leq 0.05)$.

\begin{tabular}{|c|c|c|c|}
\hline & Leaf size $\left[\mathrm{cm}^{2}\right]$ & Number of leaves & Number of buds \\
\hline \multicolumn{4}{|l|}{ Climate chamber } \\
\hline $\mathrm{VPD}=350 \mathrm{~Pa}(\mathrm{~A})$ & $14.9( \pm 0.8)^{a}$ & $12.3( \pm 2.4)^{a}$ & $9.1( \pm 0.4)^{\mathrm{a}}$ \\
\hline VPD $=930 \mathrm{~Pa}(\mathrm{~B})$ & $9.3( \pm 0.7)^{b}$ & $6.1( \pm 0.6)^{b}$ & $2.3( \pm 0.2)^{b}$ \\
\hline VPD $=1400 \mathrm{~Pa}(\mathrm{C})$ & $10.8( \pm 0.5)^{b}$ & $3.3( \pm 0.3)^{c}$ & $0.5( \pm 0.1)^{\mathrm{c}}$ \\
\hline \multicolumn{4}{|l|}{ Open-top chamber } \\
\hline ambient humidity & $10.4( \pm 0.9)^{a}$ & $16.4( \pm 1.8)^{a}$ & $11.3( \pm 1.6)^{a}$ \\
\hline reduced humidity & $8.9( \pm 4.8)^{a}$ & $12.5( \pm 0.9)^{\mathrm{b}}$ & $6.9( \pm 1.2)^{b}$ \\
\hline
\end{tabular}

Water status and water turnover of the leaves

Leaf water potential $\left(\Psi_{\mathrm{L}}\right)$ measured in the third and fourth hour of the light period on three different occasions in the climate chamber experiment decreased from - 0.44 $\mathrm{MPa}$ in the moistest treatment $(\mathrm{A}, \mathrm{VPD}=350 \mathrm{~Pa})$ to $-0.95 \mathrm{MPa}$ in the driest treatment $(C, V P D=1400 \mathrm{~Pa}$, Fig. 3A). Additionally, leaf turgor as determined by coupled water potential and pressure-volume curve data measured on three occasions during the experiment decreased significantly with increasing VPD level (Fig. 3B). This decrease amounted at about $30 \%$ in the driest treatment (VPD $=1400 \mathrm{~Pa}$ ) compared to the moistest treatment $(\mathrm{VPD}=350 \mathrm{~Pa})$. The osmotic potentials at full turgor and at turgor loss point showed only a slight, non significant decline with increasing VPD (data not shown). In this study, no evidence for an active osmotic adjustment in the dry-air treatments was detected. 

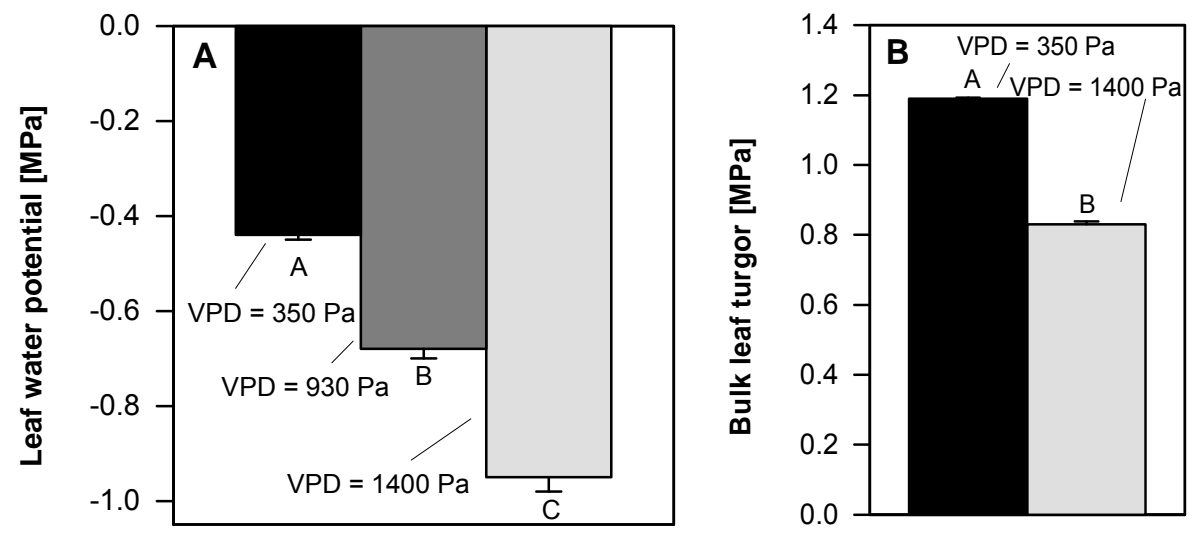

Fig. 3: Average leaf water potential and bulk leaf turgor derived from pressure-volume-curves measured on three occasions in the climate chamber experiment. Means and standard errors of 6 plants per occasion and treatment are given. Significant $(P \leq 0.05)$ differences between the treatments are marked by different letters above the columns.

Leaf conductance $\left(g_{\mathrm{L}}\right)$ for water vapor measured on six occasions during the $6^{\text {th }}$ and $7^{\text {th }}$ hour of the light period in the climate chamber experiment decreased from the low to the high VPD levels. In the driest treatment (VPD = $1400 \mathrm{~Pa}$ ), leaf conductance was on average $33 \%$ lower than $g_{\llcorner}$of the moistest treatment (VPD $=350 \mathrm{~Pa}$, Fig. 4). Despite a decrease in average leaf conductance, average transpiration rate increased from the moistest to the driest treatment with a VPD increase from 350 to $1400 \mathrm{~Pa}$ (Fig. 4).

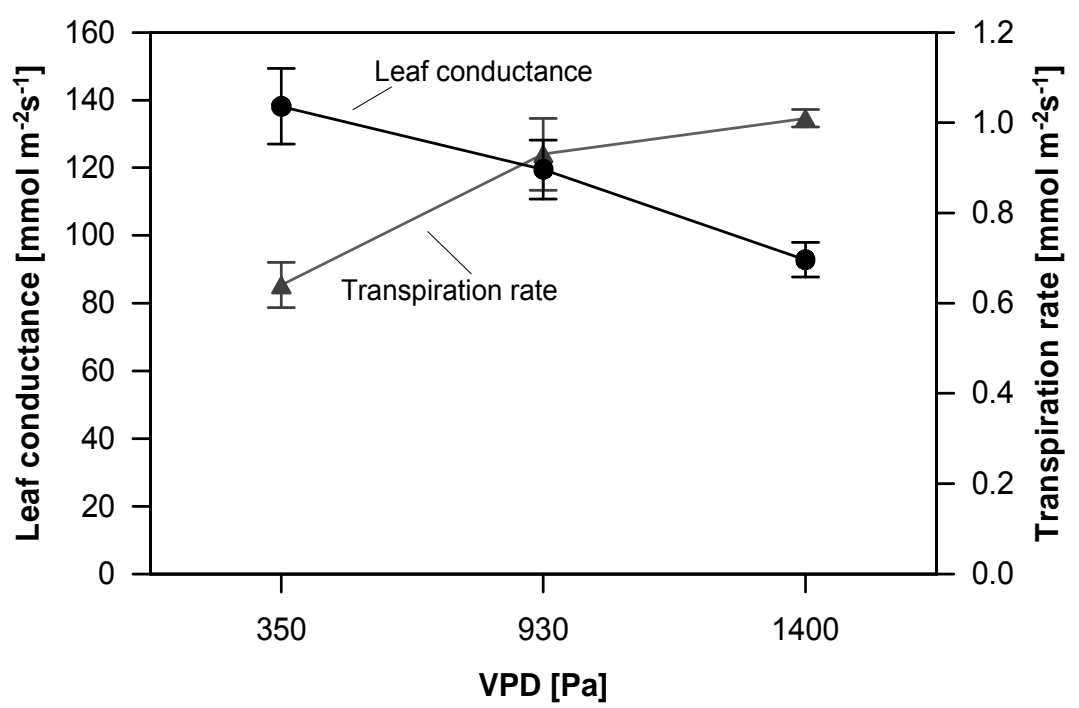

Fig. 4: Average leaf conductance and transpiration rate of the beech saplings grown in the climate chamber experiment. Means and standard errors of 40-60 replicate measurements are given. Differences between treatment A (VPD $=350 \mathrm{~Pa})$ and treatment C (VPD $=1400 \mathrm{~Pa})$ were significant $(P \leq 0.05)$ for both variables. 


\section{Discussion}

The present investigation with a combined climate chamber and open-top chamber experiment shows that the prevailing VPD level acts as an independent growthcontrolling factor for beech saplings. The results of this study demonstrate that low air humidity conditions can lead to drought stress in beech saplings even under ample soil moisture supply. In the climate chamber experiment, the biomass production declined dramatically from the low to the high VPD levels with a reduction by about $68 \%$ between the driest and the moistest treatment. The results of the open-top chamber experiment in the natural environment on the forest floor confirmed the negative effect of lowered air humidity on the growth of beech saplings. In this experiment, dry matter production declined by about $30 \%$ upon an air humidity reduction of $15 \%$. In the driest treatment of the climate chamber experiment, the saplings growth was severely depressed because nearly all leaf buds died and almost no new leaves were enfolded in the course of the experiment. The extent of growth reduction was not different from that observed in tree saplings grown under soil water limitation (BONGARTEN \& TESKY 1987, KHALIL \& GRACE 1992, PALLARDY \& RHOADS 1993, KOZLOWSKI \& PALLARDY 1997, Lebourgeois et al. 1998, Fotell et al. 2000, 2001, MEIER 2007). This is remarkable, because, in the present study, drought stress was exclusively caused by elevated VPD and not by limited soil water supply which was optimal in both experiments.

Beech seedlings and saplings are especially sensitive to soil drought when they are facing competition with the mature trees and the forest floor vegetation for soil water and nutrients (BOLTE \& ROLOFF 1993, KÖLLING et al. 2005). In numerous greenhouse and garden experiments with potted beech saplings, it was found that soil water shortage substantially reduces leaf area, shoot growth and whole-plant productivity of young beech plants (ARANDA et al. 1996, FOTELLI et al. 2001, WERNEYER 2003, CZAJKOWSKI \& BOLTE 2005, MEIER 2007). Some of these studies reported an increase in the root/shoot ratio with decreasing water availability (WERNEYER 2003), others a decrease (FOTELLI et al. 2001), whereas MEIER (2007) found no changes in the root/shoot ratio of droughted beech saplings, indicating that soil drought seems to affect the allocation patterns of young beeches only under certain conditions. One possible explanation is that the response of beech to drought stress has been found to differ between beech provenances (CZAJKOWSKI \& BOLTE 2005). Beech provenances with origin from drier climates revealed a lower sensitivity to soil drought than plants from moister sites (TOGNETTI et al. 1995, SCHRAML \& RENNENBERG 2000, CZAJKOWSKI \& BOLTE 2005). In contrast, studies with other temperate tree species found that the 
root/shoot ratio typically increased with increasing drought (BONGARTEN \& TESKY 1987, PALLARDY \& RHOAdS 1993, ASPELMEIER \& LEUSCHNER 2006). WERNEYER (2003) found no significant differences in the root/shoot ratio of beech seedlings under different air humidity treatments, but unlimited soil water supply. Similarly, in this study, no significant differences in the root/shoot ratio between the high or low air humidity levels were detected (data not shown).

In Central European beech forests, the forest floor environment is not only characterized by high soil moisture conditions but also by a generally high air humidity. Continuous measurements of the VPD on the forest floor of the Göttinger Wald beech forest by KRIEBITZSCH et al. (1985) and in the context of this study showed daytime means of VPD of 200 to $600 \mathrm{~Pa}$ in the period March to August. High air humidity levels as are common in the forest floor environment were simulated in the moistest treatment of the climate chamber experiment $(\mathrm{A}, 350 \mathrm{~Pa})$, and were approached in the control treatment of the open-top chamber experiment (582 Pa). A minor increase in VPD as it may occur during moderate summer droughts or after small changes in canopy cover of the trees was simulated in treatment $B(V P D=930 \mathrm{~Pa})$ of the climate chamber experiment, and in the reduced-humidity treatment of the open-top chamber experiment $(815 \mathrm{~Pa})$. A large increase in VPD as to be expected during extended summer droughts or in tree fall gaps was simulated in treatment C (VPD $=1400 \mathrm{~Pa})$ of the climate chamber experiment. Because the decrease in air humidity was $45 \%$ in the climate chamber experiment (from $85 \%$ to $40 \%$ ), the productivity reduction of the beech saplings was larger in this experiment than in the open-top chamber experiment where air humidity was reduced by only about $15 \%$.

The reduction in biomass production of the beech saplings under elevated VPD in this study was mainly a consequence of reduced leaf growth since the reduction in biomass in the drier treatments of both experiments was of the same size as the reduction in total leaf area. Water limitation is known to reduce leaf growth due to a reduced leaf size (FOTELLI et al. 2000) or a reduced number of leaves (DAVIES et al. 1993), or both. In drought experiments with potted tree seedlings, total leaf area, average leaf size and specific leaf area (SLA) were found to decrease under depleted soil water availability (KHALIL \& GRACE 1992, KozlowsKI \& PallaRdy 1997). In contrast, Aspelmeier \& LEUSCHNER (2006) reported an increased mean leaf size and a higher SLA in silver birch, but a reduced total leaf area with increasing water shortage because leaves were shed and the subsequently produced leaves apparently benefited from the reduced transpiring surface area. Moreover, in a transect study MEIER (2007) found an increase 
in average leaf size and stand leaf area index of mature beech trees with decreasing precipitation which contrasts with general belief. In the case of my climate chamber experiment, the leaf area reduction was a consequence of both a reduced average leaf size and a smaller number of leaves. In the open-top chamber experiment, however, the leaf area reduction was mostly caused by a reduced number of leaves developed in the reduced humidity treatment while leaf size was hardly affected. In both experiments, the largest effect was a dramatic reduction in the number of buds that were formed under a drier atmosphere. It is likely that the beech saplings growing in the driest treatment of the climate chamber experiment might have died if the experiment would have continued for a longer time because almost all buds died and no new leaves were developed.

The observed reduction in leaf growth under atmospheric drought in this study is probably a result of reductions in leaf water potential and leaf turgor which are for long known to affect leaf growth negatively (BRADFORD \& HSIAO 1982, KRAMER \& BOYER 1995). Even minimal reductions of leaf turgor or leaf water potential can cause a significant reduction of leaf expansion (ACEVEDO et al. 1971, DALE 1988, HSIAO et al. 1998), due to hydraulic effects on cell elongation rate (WESTGATE \& BOYER 1985, KRAMER 1988, GOWING et al. 1990, PASSIOURA \& FREY 1992, PASSIOURA 1994, FRENSCH 1997, HSIAO et al. 1998, MUNNS et al. 2000, SERPE \& MATTHEWS 2000), or due to a negative effect of abscisic acid on leaf growth (ZHANG \& DAVIES 1990, DODD \& DAVIES 1996, AlVES \& SETTER 2000). In the present study, leaf water potential, measured at the end of the climate chamber experiment, was lowered significantly by 0.2-0.5 MPa in plants reared at $40 \%$ air humidity. Leaf turgor measured at different occasions during the experiment was by about $30 \%$ lower compared to the moistest treatment.

Trees can respond to drought stress by several strategies. One acclimation mechanism to drought stress is osmotic adjustment. Significant osmotic adjustment as a response to drought stress have been reported for Populus tremula L., Tilia cordata Mill. (NIINEMETS et al. 1999), Fraxinus excelsior L. (PELTIER \& MARgIO 1998), Fagus grandifolia Ehrh. (TSCHAPLINSKI et al. 1998), F. crenata Blume and F. japonica Maxim. (UEMURA et al. 2000). In contrast, several authors found no osmotic adjustmant in European beech even under extreme drought stress (ARANDA et al. 1996, BACKES 1996, THOMAS 2000, SCHIPKA 2002). SCHIPKA (2002) concluded for adult beech trees that they have only a small or no ability for osmotic adjustment. Similarly, in this study no indication for active osmotic adjustment in beech saplings as a reaction to 
atmospheric drought stress was found. SCHRAML \& RENNENBERG (2000) and PEUKE et al. (2002), in contrast, at least assume that osmotic adjustment in beech trees may be possible.

A rapid response to prevent water loss under increasing plant water deficits is the closure of the stomata. Stomatal closure can be triggered by hydraulic signals (KRAMER, 1988) or chemical signals (e.g., TARDIEU \& DAVIES 1992, GoWING et al. 1993, JIA \& DAVIES 2007). In this study, average leaf conductance measured in the $6^{\text {th }}$ and $7^{\text {th }}$ $\mathrm{hr}$ of the light period was significantly smaller in the $1400 \mathrm{~Pa}$ than in the $350 \mathrm{~Pa}$ treatment of the climate chamber experiment indicating that the ruling VPD levels had resulted in a permanent partial closure of the stomata. Thus, the leaf-to-air water vapor difference seems not only to function as a signal for stomatal closure in a feedforward sense but also in a feedback mode under conditions when plants are exposed to longterm air-borne drought stress.

Although beech is generally perceived as a drought-sensitive species, some beech provenances seem to be better adapted to drought stress than others. Especially populations from the distribution boundaries of beech, where the climate is drier, may be less drought sensitive (e.g., SCHRAML \& RENNENBERG 2000). However, most data on drought tolerance of beech were obtained from seedling or sapling studies. It remains questionable whether these findings can simply be applied to adult trees to predict their sensitivity to drought under a future possibly drier climate. Thus, the recent debate on the putative vitality of beech under a changing climate (e.g., RENNENBERG et al. 2004, AMMER et al. 2005) remains mostly speculative in the absence of more precise data on the drought response of adult trees.

The creation of gaps by human activities or natural disturbances considerably alters the microclimate on the forest floor (BROSOFSKE et al. 1997, CHEN et al. 1999). For example, as more sunlight penetrates to the soil surface, temperature increases and soil moisture decreases. These changes can negatively affect the regeneration of latesuccessional shade-adapted trees (GRAY \& SPIES 1992, BUCKLEY et al. 1998). The results of the present study show that gap formation in closed forests may threaten beech seedlings and saplings not only by exposing them to heat stress, photo inhibition, and soil water depletion, but also through lowered air humidity and its effects on growth and survival. I conclude that the wide-spread shelterwood system of forest management, by which the beech canopy is opened to promote stand regeneration, must reduce the vitality of beech offspring by exposing the young plants to elevated VPD levels. 
Several studies have focused on the question how beech will respond to different silvicultural practices in a future climate. For example, FOTELLI et al. (2004) suggested that thinning under our current climate should favor the water status of beech regeneration because it reduces the water consumption of the stand. However, this practice should harm beech seedlings under a warmer and drier climate in the future. CZAJKOWSKI et al. (2005) have proposed that in future silvicultural schemes, the optimization of soil water availability will be necessary to guarantee beech regeneration. The results of the present study show that not only soil moisture is an important growth factor for beech but air humidity as well. Therefore, this factor should receive more attention in the discussion about how beech will respond to a changing climate in the future and how silviculture should be optimized in beech forests.

Air humidity could also play a role in determining the distribution range of Fagus sylvatica. According to a literature study by CZAJKOWSKI et al. (2006) it is still not completely understood wich factors are limiting the distribution of beech. The authors pointed out that a combination of precipitation, hot summers, late frost, extreme winter coldness and a short vegetation period are likely to be influential. Interestingly, some older studies already mentioned air humidity as an important factor which should influence beech distribution (DE CANDOLLE 1885, GAYER 1898, MAY 1925 in CZAJKOWSKI et al. 2006). Nevertheless, this factor was neglected in most subsequent studies dealing with beech growth and distribution. The results of my study provide solid evidence that the development of beech saplings depends strongly on high air humidity. This factor might gain of importance at the eastern and southern limits of beech distribution and also in a future drier climate. 


\section{Chapter 5}

\section{Air humidity, soil moisture and soil chemical factors as determinants of the herb layer composition in beech forests}

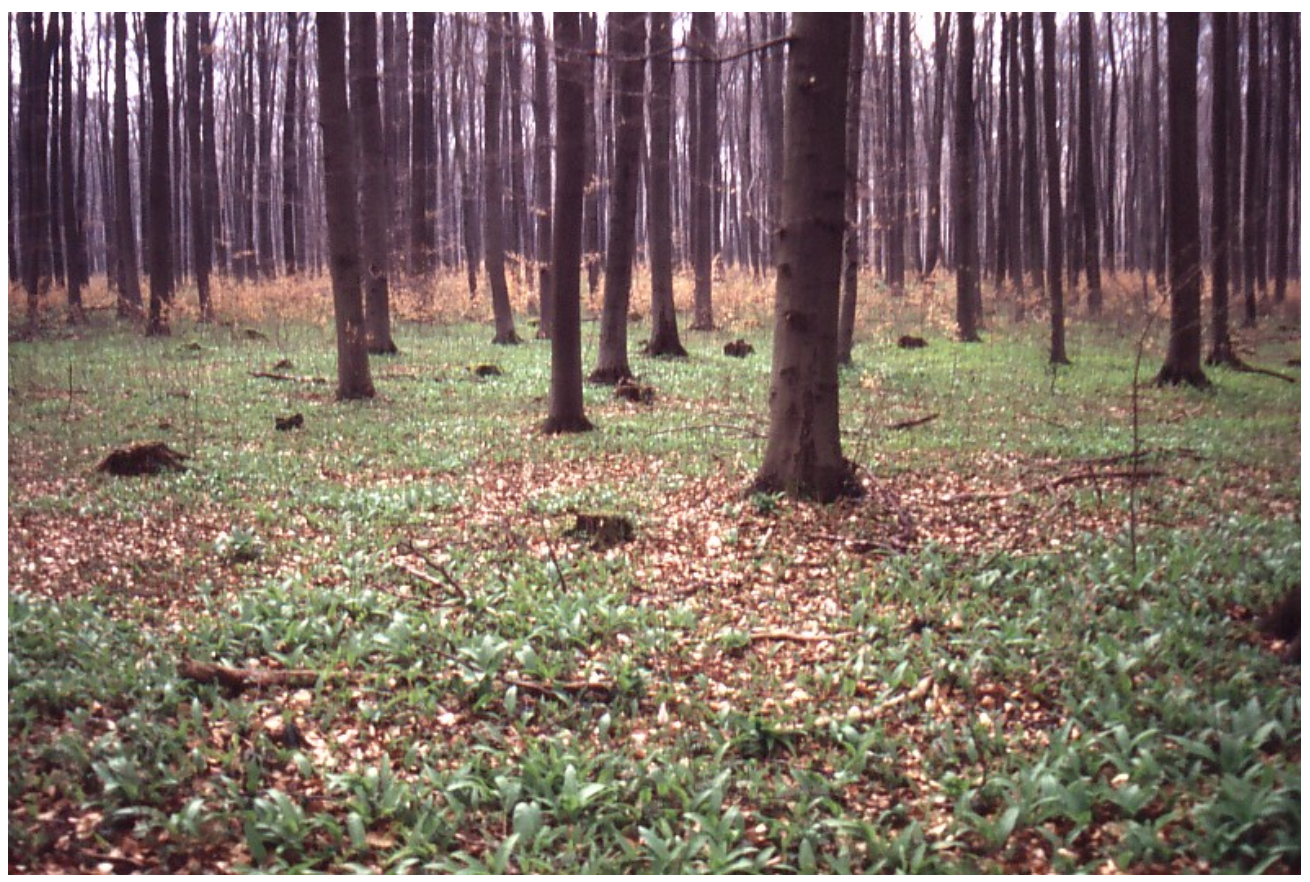




\begin{abstract}
While several abiotic and biotic factors have been investigated for their influence on the forest floor vegetation, the influence of air humidity as a site factor for forest herbs has been neglected. Study aim was to investigate the role of air humidity for the abundance and distribution of woodland herbs in comparison to other environmental factors. In beech forests on calcareous soils in southern lower Saxony, Germany, I investigated the abundance of woodland herb species and total herb cover in 60 plots on the forest floor with contrasting exposition, slope angle and relief type. On all plots, air humidity, air temperature, soil moisture, photosynthetically active radiation, $\mathrm{pH}\left(\mathrm{H}_{2} \mathrm{O}\right)$ and concentration of exchangeable $\mathrm{Ca}, \mathrm{Mg}$ and $\mathrm{K}$ were measured as well. Speciesenvironment relationships were analyzed with multiple regression analysis and CCA. Air humidity $(\mathrm{RH})$, soil moisture and the concentration of exchangeable $\mathrm{Ca}$ and $\mathrm{K}$, but not light, were identified as the most important abiotic factors influencing the cover of the most abundant plant species and total herb cover. $\mathrm{RH}$ varied substantially across the different forest floor site types and influenced species abundance independently from soil moisture. In several species (including Mercurialis perennis and Impatiens noli-tangere), $\mathrm{RH}$ was found to be a key environmental factor. Other species such as Aegopodium podagraria or Lamiastrum galeobdolon depended more on elevated soil moisture while $\mathrm{RH}$ was less important. The present study provides evidence that the distribution of widespread temperate woodland herb species depends on high air humidity and that certain sensitive species do not occur at sites with reduced air humidity even though soil moisture is high. Thus, high air humidity and ample soil moisture are key abiotic factors in beech forests on calcareous soil whereas the shade level (PPFD) was only of secondary importance for the abundance and distribution of the woodland herbs.
\end{abstract}




\section{Introduction}

On a global scale, the determining factors for canopy and ground layer species composition of forests are climate and biogeography (WEBB 1968, WHITMORE 1973, 1984, HALL \& SWAINE 1976, 1981). On a more local scale, community composition has been found to be affected by numerous abiotic and biotic site-related factors, notably topography, soil acidity, nutrient availability (BEATTY 1984, POULSON \& BALSLEV 1991, POULSON \& NiELSON 1995, POULSON 1996, SVENNING \& SKOV 2002), light regime (MARTENS et al. 2000, RANKIN \& TRAMER 2002, JELASKA et al. 2006, GÁLHIDY et al. 2006), and soil moisture (NORTH et al. 2005, GÁLHIDY et al. 2006, HOKKANEN 2006). Relevant biotic factors include dispersal abilities, competition, the disturbance regime, and herbivory.

Central European beech forests are characterized by high leaf area indices and consequently deeper shade than other broad-leaved forests, damped temperature fluctuations and generally high air humidity (ELLENBERG 1996). Several woodland herb species are physiologically and morphologically adapted to these specific conditions. Thin and hygromorphic leaves and high shade-tolerance, but sensitivity to soil drought, are typical traits of those forest floor species (ELLENBERG 1939, REHDER 1960, HOFLACHER \& BAUER 1982, ROgERS 1982).

Soil moisture has been found to have a strong effect on herb distribution patterns and herb cover in forests (WhITTAKER 1956, RUNKLE \& WhitNey 1987, POULSEN 1996, NORTH et al. 2005, GÁLHIDY et al. 2006, HOKKANEN 2006), while information on air humidity, which is another important factor of the hydrologic regime, has been neglected (ELLENBERG 1996). This is surprising because air humidity has already been found to have a strong influence on the growth and development of temperate woodland herbs in glasshouse experiments (LEUSCHNER 2002). Given that plants are an integral element of the soil-plant-atmosphere continuum of water flux, herb distribution should depend on both soil water and atmospheric water status.

In the sub-oceanic part of Central Europe, the natural forest community on limestone is the Hordelymo-Fagetum beech forest association which is characterized by a speciesrich herb flora. Daytime measurements of the water vapor saturation deficit on the forest floor revealed small VPD values between 200 and $500 \mathrm{~Pa}$ (KRIEBITZSCH et al. 1985), indicating that woodland herbs most of their life-time are exposed to high air humidity in this environment. However, the relief should modify the microclimate near the ground and may also alter the soil moisture regime in different topographic 
positions inside the forest. For example, on south-facing slopes, air humidity will be lower than on north-facing slopes or in valleys. I expect that many woodland herbs will depend not only on ample soil moisture supply but also on high air humidity. Therefore, species diversity and cover of typical woodland herbs should be higher at sites with high air humidity as in valleys or north-facing slopes compared to sites with low air humidity (e.g., sunny slopes or canopy gaps).

The species-rich herb layer of Central European beech forests on limestone has been in the focus of intensive ecological research. Topics of research have been the floristic composition (DIERSCHKE 1989, ELLENBERG 1996), plant phenology (DIERSCHKE 1989), small scale distribution patterns of the species (DIERSCHKE \& SONG 1982), biomass production (EGGERT 1985, SCHMIDT et al. 1989), the light regime (EBER 1972, EHRHARDT 1988), the $\mathrm{CO}_{2}$ - and $\mathrm{H}_{2} \mathrm{O}$-gas exchange (KRIEBITZSCH 1989), biomass energy content (HELLMOLD \& SCHMIDT 1989), and inter-annual fluctuations in the herb layer (SCHMIDT 1988). The small-scale distribution of several species such as Mercurialis perennis, Anemone nemorosa, Allium ursinum, Stachys sylvatica and Lamiastrum galeobdolon was related to soil properties (soil chemical parameters and soil moisture), light availability and dispersal abilities. For certain species such as $A$. ursinum it has been assumed that they might prefer sites with high air humidity (FISCHER 1981, KRIEBITZSCH 1989). However, these authors did not focus on the soil water-independent effects of air humidity on the woodland herbs. Attempts to identify the key environmental factors determining the abundance and the distribution of woodland herbs must remain incomplete as long as air humidity is not included in the analysis.

The present study in a limestone beech forest investigates the distribution of woodland herbs and their dependence on environmental factors with a focus on soil moisture and air humidity. Study aims were to assess (i) how air humidity varies inside the forest floor across a variety of sites defined by topography, (ii) which abiotic factor is most important in determining abundance and distribution of herb species, and (iii) whether typical woodland herbs are more dependent on high air humidity or high soil moisture.

\section{Material and methods}

Study area

The study was conducted in an extended area of beech forest on calcareous soils in Central Germany (southern Lower Saxony, $51^{\circ} 32^{`} \mathrm{~N}, 10^{\circ} 03^{\circ} \mathrm{E}$ ). Altitude in the area varies from 130 to $430 \mathrm{~m}$ a.s.I. Most of the forest consists of a 100- to 130-year-old 
beech forest with a species-rich herb layer including spring geophytes and shadetolerant summer herbs and grasses. The climate has a sub-oceanic to sub-continental character. Annual mean temperature is $7.9^{\circ} \mathrm{C}$, mean annual rainfall $720 \mathrm{~mm}$. The bedrock is Triassic limestone overlain by a mull humus soil. The natural forest community of the study area is the Hordelymo-Fagetum beech forest association which is characterized by a number of woodland herb species with large meso- to hygromorphic leaves. Typical species are Allium ursinum L. (Alliaceae), Mercurialis perennis L. (Euphorbiaceae), Anemone nemorosa L. (Ranuculaceae), Lamiastrum galeobdolon (L.) Ehrend. \& Polatsch (Lamiaceae), Hepatica nobilis Mill. (Ranuculaceae) and Asarum europeaum L. (Aristolochiaceae).

\section{Vegetation analysis and microclimate and soil moisture measurements}

The field work was undertaken during spring 2006 (March to May) before leaf flushing of beech; this period includes the activity maximum of spring geophytes and various summer perennials of the woodland flora. Six different site types on the forest floor that were assumed to have contrasting microclimate and edaphic characteristics were selected for the study. Each site type was represented by 10 plots à $10 \mathrm{~m} \times 10 \mathrm{~m}$ that were selected by random in sections of the forest fulfilling pre-definded site selection criteria. Thus, 60 plots with contrasting exposition (north or south), slope angle (low or high) and relief type (valley bottoms, open or sheltered) where chosen. The six site types were: $(A)$ sheltered valleys, $(B)$ open valleys, $(C)$ shallow north-facing slopes, (D) steep north-facing slopes, $(E)$ shallow south-facing slopes, and (F) steep south-facing slopes. Shallow slopes had a maximum inclination of $12 \%$, while steep slopes ranged between $14 \%$ and $28 \%$. The minimum distance between the plots of a given site was 5 $\mathrm{km}$, and the minimum distance between the plots of different sites types was $500-800$ m. On each plot, I recorded the cover of all woodland herb species according to the LONDO scala $(1976,1984)$, and estimated total species and herb cover, canopy cover and plot inclination.

Air humidity and air temperature were recorded from March to May 2006 with microweather stations consisting of an air temperature and a capacitative air humidity sensor (DS 1923, Maxim/Dallas, USA) equipped with a self-constructed radiation shield. In the centre of each plot, the micro-weather station was installed at $0.5 \mathrm{~m}$ height above the herb layer. Air humidity and temperature were measured continuously every minute, and the averaged data were recorded every $15 \mathrm{~min}$. For statistical analysis, mean values of the day-light period were used. On each of the 60 plots, the flux density of photosynthetically active radiation (PAR) was measured one meter above the herb 
layer with LI-1000 quantum flux sensors (LiCor Biosciences, Lincoln, NE, USA). Measurements were conducted every week in the time period between noon and 2:00 pm under comparable weather conditions, i.e. cloudy sky and no rain. In total, about 40-60 individual PAR measurements were conducted per plot over a period of 12 weeks (March to May) in order to obtain mean values of transmitted PAR.

Soil moisture was determined gravimetrically at weekly intervals based on three samples taken per plot at 0-20 cm depth. Soil samples for chemical analysis were collected from three randomly selected locations per plot at a depth of $0-20 \mathrm{~cm}$. The three replicate samples were mixed and used as one sample in the subsequent analyses.

\section{Soil chemical analysis}

The $\mathrm{pH}\left(\mathrm{H}_{2} \mathrm{O}\right)$ of the fresh soil was measured with a glass electrode in a suspension of $10 \mathrm{~g}$ of soil material and $25 \mathrm{ml}$ of distilled water. The remaining soil material was dried at $40{ }^{\circ} \mathrm{C}$ for $48 \mathrm{~h}$, and the concentration of salt-extractable cations of the soil was determined by percolating $2.5 \mathrm{~g}$ soil with $100 \mathrm{ml}$ of $1 \mathrm{M} \mathrm{BaCl}_{2}$ solution for 6 hours. The concentrations of $\mathrm{Mg}, \mathrm{Ca}, \mathrm{K}$ in the percolate were then analyzed by atomic absorbtion spectroscopy (AAS) (Vario 6, Analytik Jena, Germany). The C/N ratio was measured with an elemental analyzer in samples dried at $70{ }^{\circ} \mathrm{C}$ for $48 \mathrm{~h}$ (Elementar, Hanau, Germany).

\section{Statistical analysis}

A multiple regression analysis was conducted with the program SYSTAT 10 (Systat Software Inc., California, USA) in order to detect the environmental factors that influence the abundance of selected woodland herb species and total herb cover on the forest floor. For identifying those factors which had the largest influence on total herb cover and the abundance of important species, a stepwise additive multiple regression analysis was conducted. Subsequently, the ordination program CANOCO (TER BRAAK \& SMILAUER 2002) was used for analyzing the relationship between species abundance and environmental variables. A Detrended Correspondence Analysis (DCA) was used to define the length of the gradients (species turnover). It has been recommended to use unimodal methods for gradients $>4 \mathrm{SD}$, and linear methods for gradients $<3$, while for gradients between 3 and 4 SD, both methods may be suitable (LEYER \& WESCHE 2007). For the present data set, the DCA revealed gradient lengths between 3 and $4 \mathrm{SD}$, and I decided to use a Canonical Correspondence Analysis (CCA) (TER BRAAK 1986) to analyze species-environment relationships. CCA is an 
unimodal ordination technique that incorporates multiple regressions, with the ordination axes constrained as linear combinations of environmental variables, and relates species composition directly to the environmental predictor variables (TER BRAAK 1986, 1987). In a preliminary CCA analysis, a manual forward selection procedure was conducted to select the main environmental variables $(P \leq 0.05)$. Variables were tested for their significance using a Monte Carlo permutation test (999 permutations), and only the significant variables were included in the CCA. The variables soil moisture $(P=0.002)$, air humidity $(P=0.002)$, air temperature $(P=$ $0.004)$, inclination $(P=0.002)$, calcium concentration $(P=0.04)$ and potassium concentration $(P=0.006)$ were used for the final CCA. Rare species were excluded from the CCA. For the final CCA, a Monte Carlo permutation test was used to determine the significance of each axis and of all axes together $(P \leq 0.05)$. The nonparametric Kruskal-Wallis test was used to test if climate or soil factors differed between the six site types $(P \leq 0.05)$.

\section{Results}

\section{Environmental conditions of the site types}

The lowest vapor pressure deficits (mean daytime values, averaged over the twelveweek observation period) were recorded in sheltered valley plots (VPD = $153 \mathrm{~Pa}$ ) and north-facing slope plots either with low or high inclination (VPD $=363 \mathrm{~Pa}$ or $385 \mathrm{~Pa}$, respectively). In contrast, in open valley plots, average VPD levels were considerably higher with $527 \mathrm{~Pa}$. The highest average VPD levels were found on south-facing slope plots with $669 \mathrm{~Pa}$ (low inclination) and $750 \mathrm{~Pa}$ (high inclination) (Table 1).

Mean daytime temperatures averaged over the twelve-week observation period showed the same tendency as the vapor pressure deficit. They were generally higher on south-facing slopes than on north-facing slopes and valley bottoms. The photosynthetically active radiation (PAR) measured during midday was on average higher on south-exposed slopes than on north-exposed slopes and valleys, but showed lower variation than VPD and temperature (Table 1).

The highest soil moisture levels were recorded in sheltered and open valleys as well as on northern slopes. While VPD levels showed marked differences between sheltered and open valley plots, soil moisture exhibited no significant differences between these two site types. On the north-facing slope plots, soil moisture values were very similar to those measured in the valley plots and showed no significant differences between shallow and steep slopes. The $\mathrm{pH}$ values were not significantly different between the 
six site types at all. The lowest concentration of exchangeable calcium in the soil was found in the open valley plots, whereas exchangeable Ca was not significantly different between the other five site types. The concentrations of exchangeable $\mathrm{K}, \mathrm{Mg}$ and the $\mathrm{C} / \mathrm{N}$ ratio were also very similar among the six site types (Table 1 ). 
Table 1: Microclimate and soil variables at the six site types investigated during the spring season (March to May 2006). For microclimate variables, the daytime means with standard errors are given for the different sites. The soil parameters refer to the topsoil $(0-10 \mathrm{~cm}) ; \mathrm{Ca}, \mathrm{K}$ and $\mathrm{Mg}$ are salt-exchangeable concentrations. Significant $(P \leq 0.05)$ differences between the sites are marked by different letters.

\begin{tabular}{|c|c|c|c|c|c|c|}
\hline & \multicolumn{2}{|c|}{ Valley bottom } & \multicolumn{2}{|c|}{ North-facing slopes } & \multicolumn{2}{|c|}{ South-facing slopes } \\
\hline & open & closed & shallow & steep & shallow & steep \\
\hline $\mathrm{T}\left[{ }^{\circ} \mathrm{C}\right]$ & $13.1( \pm 1.4)^{a}$ & $11.4( \pm 0.7)^{b}$ & $12.1( \pm 0.8)^{\mathrm{ab}}$ & $12.7( \pm 0.9)^{\mathrm{ab}}$ & $15.3( \pm 0.8)^{c}$ & $16.2( \pm 1.3)^{\mathrm{c}}$ \\
\hline $\mathrm{RH}[\%]$ & $69.3( \pm 2.7)^{\mathrm{a}}$ & $89.4( \pm 1.6)^{b}$ & $76.5( \pm 3.3)^{a}$ & $74.4( \pm 3.1)^{a}$ & $64( \pm 4.7)^{\mathrm{ac}}$ & $59.6( \pm 4.9)^{\mathrm{C}}$ \\
\hline VPD $[\mathrm{Pa}]$ & $527( \pm 90.1)^{a}$ & $153( \pm 30.4)^{b}$ & $363( \pm 59.2)^{\mathrm{c}}$ & $385( \pm 58)^{c}$ & $669( \pm 114)^{\mathrm{ad}}$ & $750( \pm 86.1)^{d}$ \\
\hline $\operatorname{PAR}\left[\mu \mathrm{mol} \mathrm{m} \mathrm{m}^{-2} \mathrm{~s}^{-1}\right]$ & $451( \pm 13.8)^{a}$ & $434( \pm 11.5)^{\mathrm{a}}$ & $305( \pm 49)^{\mathrm{b}}$ & $339( \pm 17.4)^{b}$ & $470( \pm 12)^{a}$ & $508( \pm 36.9)^{\mathrm{ac}}$ \\
\hline Soil moisture [vol\%] & $34.7( \pm 1.2)^{\mathrm{a}}$ & $36.4( \pm 0.8)^{a}$ & $36.1( \pm 0.9)^{a}$ & $33.2( \pm 2.7)^{a}$ & $28.1( \pm 3.5)^{b}$ & $25.2( \pm 2.3)^{b}$ \\
\hline $\mathrm{pH}\left(\mathrm{H}_{2} \mathrm{O}\right)$ & $7.3( \pm 0.1)^{\mathrm{a}}$ & $7.1( \pm 0.1)^{a}$ & $7.2( \pm 0.2)^{a}$ & $7.4( \pm 0.1)^{a}$ & $7.3( \pm 0.1)^{a}$ & $7.3( \pm 0.4)^{a}$ \\
\hline $\mathrm{Ca}\left[\mu \mathrm{mol} \mathrm{g}{ }^{-1}\right]$ & $141( \pm 18.8)^{a}$ & $251( \pm 30)^{b}$ & $247( \pm 27.6)^{b}$ & $203( \pm 25.2)^{b}$ & $219( \pm 20.5)^{b}$ & $203( \pm 20.9)^{b}$ \\
\hline $\mathrm{K}\left[\mu \mathrm{mol} \mathrm{g}{ }^{-1}\right]$ & $5.3( \pm 0.6)^{a}$ & $8.0( \pm 0.6)^{b}$ & $7.8( \pm 0.5)^{b}$ & $6.7( \pm 0.7)^{\mathrm{ab}}$ & $7.9( \pm 0.5)^{b}$ & $7.6( \pm 0.7)^{b}$ \\
\hline $\mathrm{Mg}\left[\mu \mathrm{mol} \mathrm{g}{ }^{-1}\right]$ & $7.1( \pm 0.9)^{a}$ & $8.6( \pm 0.8)^{b}$ & $7.6( \pm 0.6)^{\mathrm{ab}}$ & $7.3( \pm 0.6)^{a}$ & $6.7( \pm 0.3)^{a}$ & $7.5( \pm 0.8)^{a}$ \\
\hline $\mathrm{C} / \mathrm{N}$ ratio & $14.8( \pm 1.6)^{a}$ & $14.1( \pm 0.8)^{a}$ & $13.4( \pm 0.5)^{\mathrm{a}}$ & $13.3( \pm 0.6)^{\mathrm{a}}$ & $15.5( \pm 1.3)^{\mathrm{ab}}$ & $14.6( \pm 1.6)^{a}$ \\
\hline
\end{tabular}


The Canonical Correspondence Analysis (CCA) revealed that air humidity and temperature were negatively related to each other while there was no strong correlation between air humidity and soil moisture (Fig. 1). This result was further confirmed by a regression analysis, which also showed that air humidity and soil moisture were acting independently from each other $\left(r^{2}=0.181, P=0.163\right)$. In addition, there was a positive correlation between the amounts of salt-exchangeable $\mathrm{Ca}, \mathrm{Mg}$ and $\mathrm{K}$. However, there was no correlation between the cation-concentrations and the other measured environmental parameters.

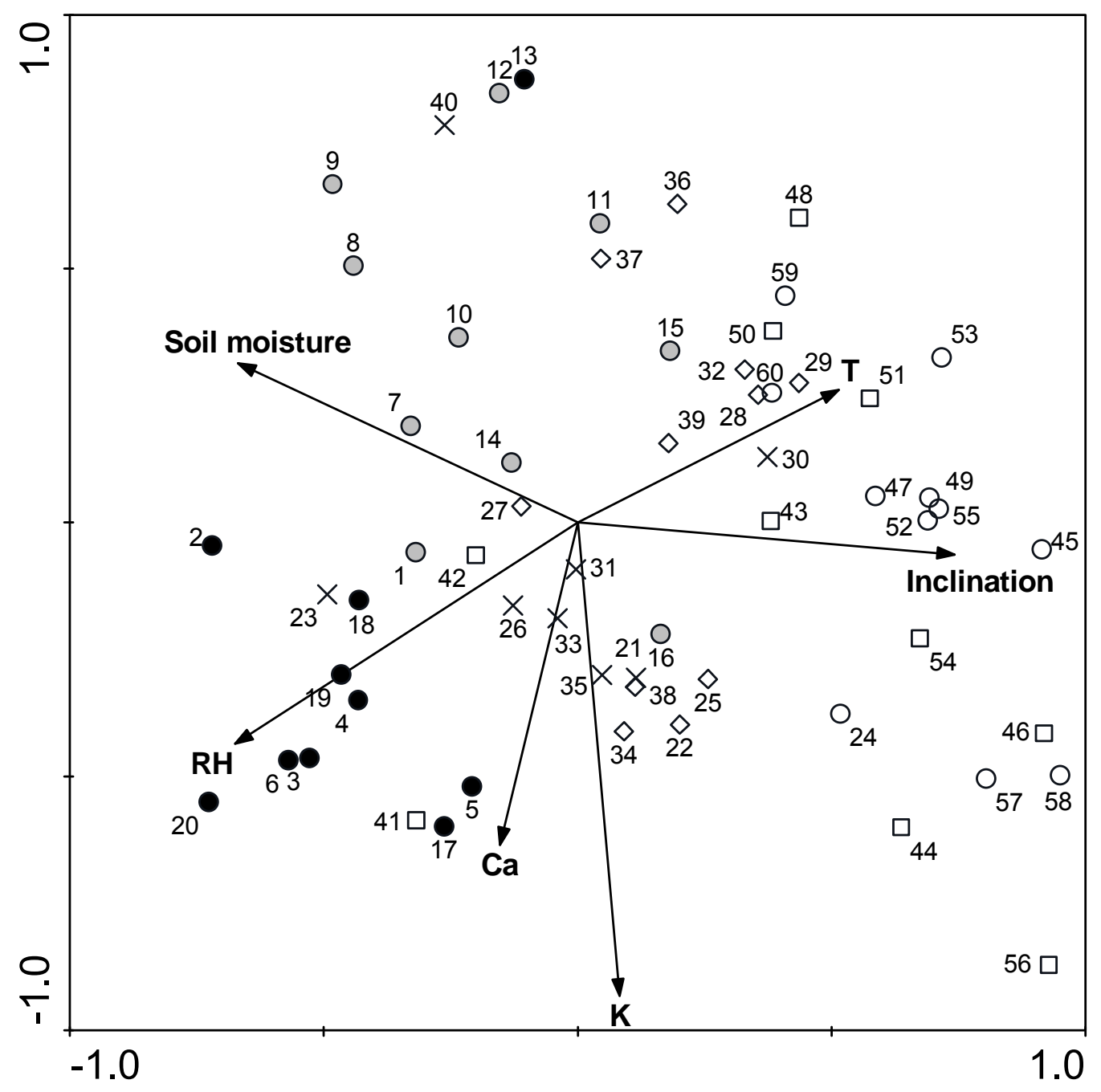

Fig. 1: First and second axes of the CCA ordination (biplot scaling) for the correlation between the six site types and six environmental variables. (a) sheltered valley plots = black points, (b) open valley plots $=$ grey points, (c) north-facing plots with low inclination $=x$-marks, (d) northfacing plots with high inclination = diamonds, $(\mathrm{e})$ south-facing plots with low inclination = squares, and (f) south-facing plots with low inclination = unfilled circles. 
The CCA showed that the valley plots were characterized by generally high soil moisture but that air humidity was very sensitive to valley topography (sheltered or open, Fig. 1). Sheltered valley plots (e.g., \# 3, 4, 6, 18, 19, and 20) were characterized by high air humidity whereas in open valley plots (e.g., \#10,11,12, 14, and 15), air humidity was significantly lower. Shallow north-facing slope plots (e.g., \# 23, 26, and 33) showed a higher correlation to air humidity than steep north-facing slope plots (e.g., \# 29, 32, and 39). Moreover, north-facing slope plots were most closely associated with higher calcium and potassium concentrations. South-facing slope plots of low or high inclination assembled only on the right site of the figure, indicating that these sites were characterized by low air humidity and soil moisture but higher temperatures (Fig. 1).

Herb distribution patterns

The highest herb cover with a mean of $88 \%$ was recorded in sheltered valleys, the lowest with $52 \%$ on south-facing slopes with high inclination. Herb cover was linked to both high soil moisture and air humidity; the regression analysis revealed similar correlation coefficients (and P-values) for both environmental variables (Fig. 3). The composition of the herbaceous layer changed remarkably between the six site types. In open and sheltered valleys, the plots had either a species-rich herb layer consisting of species preferring humid habitats (e.g., Aegopodium podagraria, Impatiens nolitangere and Circaea lutetiana), or species with rapid clonal growth such as Allium ursinum or Mercurialis perennis formed dense carpets, and consequently the number of other species was low. These two species were more abundant on sheltered than on open valley plots. On the latter, species like Anemone nemorosa occurred more frequently. 
Table 2: Estimated cover values of some abundant woodland herbs at the six site types (means of ten plots á $10 \times 10 \mathrm{~m}$ ). Cover values were estimated according to LONDO $(1976,1984)$ and are given as percentage. Aeg pod $=$ Aegopodium podagaria, All urs $=$ Allium ursinum, Ane nem $=$ Anemone nemorosa, Ane ran $=$ Anemone ranunculoides, Asa eur $=$ Asarum europaeum, Cir lut $=$ Circaea lutetiana, $\mathrm{Gal}$ odo $=$ Galium odoratum, Hep nob $=$ Hepatica nobilis, $\mathrm{Imp}$ nol $=$ Impatiens noli-tangere, Lam gal = Lamiastrum galeobdolon, Mer per = Mercurialis perennis, Sta syl = Stachys sylvatica.

\begin{tabular}{|c|c|c|c|c|c|c|}
\hline & \multicolumn{2}{|c|}{ Valley bottom } & \multicolumn{2}{|c|}{ North-facing slope } & \multicolumn{2}{|c|}{ South-facing slope } \\
\hline & open & closed & shallow & steep & shallow & steep \\
\hline Aeg pod & $15-25$ & $15-25$ & $3-5$ & $1-3$ & 0 & 0 \\
\hline All urs & $55-65$ & $65-75$ & $45-55$ & $3-5$ & 0 & 0 \\
\hline Ane nem & $25-35$ & $15-25$ & $15-25$ & $25-35$ & $25-35$ & $25-35$ \\
\hline Ane ran & $5-15$ & $5-15$ & $3-5$ & $5-15$ & $3-5$ & $3-5$ \\
\hline Asa eur & $1-3$ & $1-3$ & $>1$ & $1-3$ & $>1$ & $>1$ \\
\hline Cir lut & $3-5$ & $3-5$ & $3-5$ & $1-3$ & 0 & 0 \\
\hline Gal odo & $3-5$ & $3-5$ & $1-3$ & $1-3$ & $5-15$ & $5-15$ \\
\hline Hep nob & $1-3$ & $1-3$ & $>1$ & $1-3$ & $>1$ & $>1$ \\
\hline Imp nol & $3-5$ & $3-5$ & $1-3$ & $1-3$ & 0 & 0 \\
\hline Lam gal & $5-15$ & $3-5$ & $3-5$ & $3-5$ & 0 & 0 \\
\hline Mer per & $5-15$ & $25-35$ & $15-25$ & $5-15$ & $1-3$ & $1-3$ \\
\hline Sta syl & $3-5$ & $3-5$ & $3-5$ & $1-3$ & 0 & 0 \\
\hline
\end{tabular}

The floristic composition of north-facing slope plots was very similar to that of the valley plots but species such as $A$. podagraria, I. noli-tangere and C. lutetiana were less frequent. Allium ursinum was more abundant on plots with low inclination, while $M$. perennis was equally abundant on plots with low or high inclination. Similar to the valley plots, north-facing plots with dense carpets of $A$. ursinum or $M$. perennis were less species-rich.

On south-facing slopes, the floristic composition was markedly different from the valley and north-facing slope plots. Species like A. ursinum, A. podagraria, I. noli-tangere and C. Iutetiana were completely absent and dense carpets of a single woodland herb species were also missing (Table 2). The herb cover at these sites was patchy and species like Hedera helix had a high frequency. 
Table 3: Results of a multiple regression analysis and stepwise additive multiple regression analysis for the effect of various environmental parameters on the cover of seven abundant woodland herb species and total herb cover in 60 plots. Given are the correlation coefficients $r^{2}$. Importance $1=$ factor with the highest correlation coefficient, importance $2=$ combination of factor one and the next most important factor, importance $3=$ combination of the first two most important factors and the next most important factor. The multiple regression analysis included all investigated environmental factors.

${ }^{*}=P \leq 0.05,{ }^{* *}=P \leq 0.01,{ }^{* * *}=P \leq 0.001$.

Aeg pod = Aegopodium podagaria, All urs = Allium ursinum, Imp nol = Impatiens noli-tangere, Lam gal = Lamiastrum galeobdolon, Mer per = Mercurialis perennis, Ran fic $=$ Ranunculus ficaria, Sta syl $=$ Stachys sylvatica. $\mathrm{SM}=$ Soil moisture, $\mathrm{RH}=$ relative air humidity, Incl. $=$ Inclination, $\mathrm{T}=\mathrm{Temperature}, \mathrm{Ca}=$ exchangeable calcium concentration, $\mathrm{K}=$ exchangeable potassium concentration, $\mathrm{C} / \mathrm{N}=\mathrm{C} / \mathrm{N}$ ratio, $\mathrm{PAR}=$ photosynthetically active radiation.

\begin{tabular}{|c|c|c|c|c|c|c|c|c|}
\hline $\begin{array}{l}\text { Most important } \\
\text { factors }\end{array}$ & $\begin{array}{c}\text { Total herb } \\
\text { cover }\end{array}$ & Aeg pod & All urs & Imp nol & Lam gal & Mer per & Ran fic & Sta syl \\
\hline 1 & $\mathrm{SM}=0.560^{*}$ & $S M=0.651^{*}$ & Incl. $=-0.653^{*}$ & $\mathrm{RH}=0.513^{*}$ & $S M=0.502^{*}$ & $\mathrm{RH}=0.435$ & $\mathrm{~K}=-0.497$ & $K=-0.465$ \\
\hline 2 & $+\mathrm{RH}=0.719^{* *}$ & $+\mathrm{K}=0.807^{* *}$ & $+\mathrm{RH}=0.738^{*}$ & $+\mathrm{C} / \mathrm{N}=0.638^{*}$ & $+\mathrm{C} / \mathrm{N}=0.630^{*}$ & $+K=0.482$ & $+\mathrm{RH}=0.625^{\star *}$ & $+\mathrm{RH}=0.613^{*}$ \\
\hline 3 & $+\mathrm{Ca}=0.762^{* *}$ & $+\mathrm{RH}=0.821^{* *}$ & $+T=0.809^{* * *}$ & $+\mathrm{PAR}=0.774^{* *}$ & $+K=0.653^{*}$ & $+\mathrm{Ca}=0.528^{*}$ & $+\mathrm{SM}=0.753^{* *}$ & $+\mathrm{C} / \mathrm{N}=0.689^{* *}$ \\
\hline All factors & $0.792^{* *}$ & $0.958^{* * *}$ & $0.815^{* * *}$ & $0.916^{* * *}$ & $0.680^{* *}$ & $0.554^{*}$ & $0.815^{\star *}$ & $0.728^{* *}$ \\
\hline
\end{tabular}


According to the multiple regression analysis, the eight investigated environmental factors had a highly significant influence on total herb cover and the abundance of seven important herb species. The stepwise additive multiple regression analysis revealed that the most important abiotic factors influencing the woodland herb species were air humidity, soil moisture, and the concentration of exchangeable potassium. Total herb cover was mainly determined by soil moisture and air humidity (Table 3 ). Only in the case of $I$. noli-tangere, a significant influence of photosynthetically active radiation was detected. Furthermore, the concentration of exchangeable $\mathrm{Mg}$ and the $\mathrm{pH}$-value had no influence on total herb cover and on the abundance of the seven species.

The CCA results supported the outcome of the multiple regression analysis by showing the large influence of the tested environmental variables on the herb species (Fig. 3). The cumulative percentage variances for the species-environmental relations were high: $56.3 \%$ for the first and $76.1 \%$ for the second axes, with significant correlations yielded by the Monte Carlo permutation test $(P=0.01)$, and carried out for all axes $(P=$ 0.02). The CCA eigenvalues of the first two axes were relatively low, indicating a relatively short gradient (Table 4). Since the manual forward selection indicated that the influences of $\mathrm{pH}$ and PAR were not significant, these variables were excluded from the CCA.

Table 4: Results of the CCA analysis. Given are the eigenvalues, the species-environment correlations, the variance of species cover, and the variance of species-environment relations for the first four axes. Significance of all axes was tested with a Monte Carlo permutation test (999 permutations). Significance was determined at $P \leq 0.05$.

\begin{tabular}{lcccc}
\hline Axes & $\mathbf{1}$ & $\mathbf{2}$ & $\mathbf{3}$ & $\mathbf{4}$ \\
\hline Eigenvalues & 0.394 & 0.118 & 0.053 & 0.047 \\
Species-environment correlations & 0.824 & 0.630 & 0.409 & 0.410 \\
Variance of species cover [\%] & 20.1 & 27.2 & 30.1 & 33.0 \\
Variance of species-environment relations [\%] & 56.3 & 76.1 & 84.4 & 92.4 \\
\cline { 2 - 6 } Monte Carlo test for all axes & & & & $P=0.02$ \\
\hline
\end{tabular}

Similar to the stepwise additive multiple regression analysis, the CCA revealed that the woodland herb species were mainly affected by air humidity, soil moisture and selected soil chemical factors, in particular the concentration of exchangeable $\mathrm{K}$ and $\mathrm{Ca}$. Most of the species covaried in their abundance with the soil moisture axis indicating that they preferred sites with high soil moisture. Additionally, the distribution of the species was affected by air humidity and the species showed a contrasting distribution pattern along the air humidity-temperature axis. Some species such as $A$. ursinum, C. lutetiana, $S$. 
sylvatica and I. noli-tangere showed a correlation with high air humidity whereas other species such as $P$. officinalis and $A$. nemorosa occurred on sites with lower air humidity.

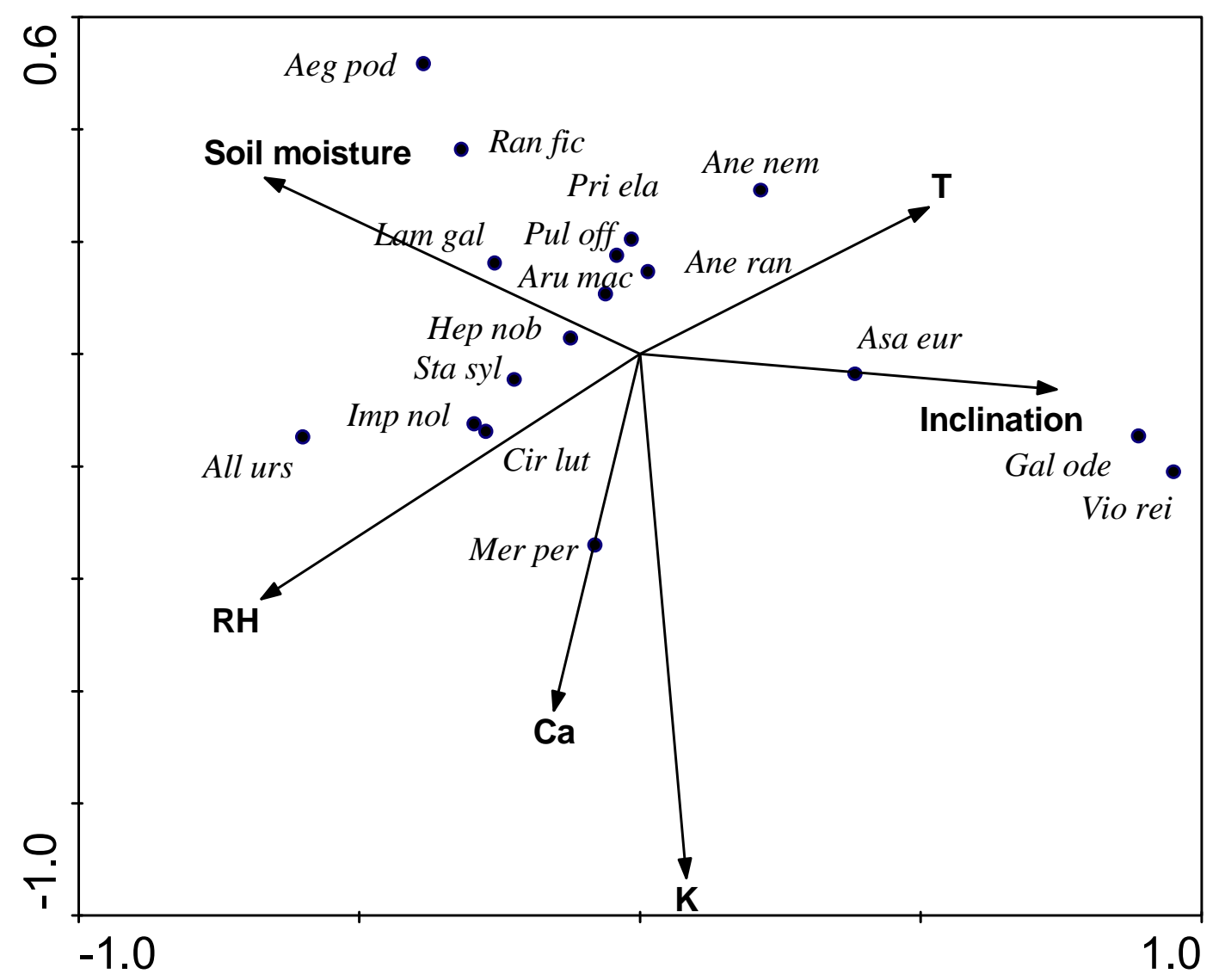

Fig. 2: First and second axes of the CCA ordination (biplot scaling) for the most abundant woodland herbs of the study area and their correlation to six environmental variables.

Aeg pod = Aegopodium podagaria, All urs = Allium ursinum, Ane nem = Anemone nemorosa, Ane ran $=$ Anemone ranunculoides, Aru $\mathrm{mac}=$ Arum maculatum, Asa eur $=$ Asarum europaeum, Cir lut $=$ Circaea lutetiana, Gal odo $=$ Galium odoratum, Hep nob $=$ Hepatica nobilis, $\mathrm{Imp}$ nol = Impatiens noli-tangere, Lam gal = Lamiastrum galeobdolon, Mer per = Mercurialis perennis, Pri ela $=$ Primula elatior, Pul off $=$ Pulmonaria officinalis, Ran fic $=$ Ranunculus ficaria, Sta syl $=$ Stachys sylvatica, Vio rei $=$ Viola reichenbachiana .

Other species such as $L$. galeobdolon, $R$. ficaria and $A$. podagraria were more affected by soil moisture than by air humidity. Only a few species (Viola reichenbachiana, Galium odoratum) were more abundant at sites with both lower air humidity and lower soil moisture; those species showed a positive correlation with slope angle. Mercurialis perennis was more abundant at sites with high concentrations of $\mathrm{Ca}$ and were air humidity was high. Sites with high concentrations of exchangeable potassium were not preferred by any species. It appeared that most species seemed to occur more 
frequently at sites with lower potassium concentrations, which is also in accordance to the results of the multiple regression analysis.

\section{Discussion}

In the present study, soil moisture was one of the most important factors influencing herb abundance and distribution patterns in a temperate broad-leaved forest. A similar dependence on soil moisture has been documented by numerous other studies (e.g., WHITTAKER 1956, NORTH et al. 2005, GÁLHIDY et al. 2006, HOKKANEN 2006). Many woodland herbs are thought to be sensitive to soil drought, and thus they were expected to respond strongly to gradients in water availability as they are characteristic for topographically diverse forest landscapes (COSTA 2006). Moreover, the species richness of the herb layer of temperate forests typically increases with soil moisture (GRAAE \& HeskJAer 1997, PAusas \& Austin 2001, HÄRDTLE et al. 2003). This study provided evidence for the fact that the herb cover also depends on the prevailing air humidity level. The highest cover values were recorded on plots with both high soil moisture and high air humidity. A regression analysis revealed similar correlation coefficients for herb cover and air humidity, and herb cover and soil moisture (Fig. 3).
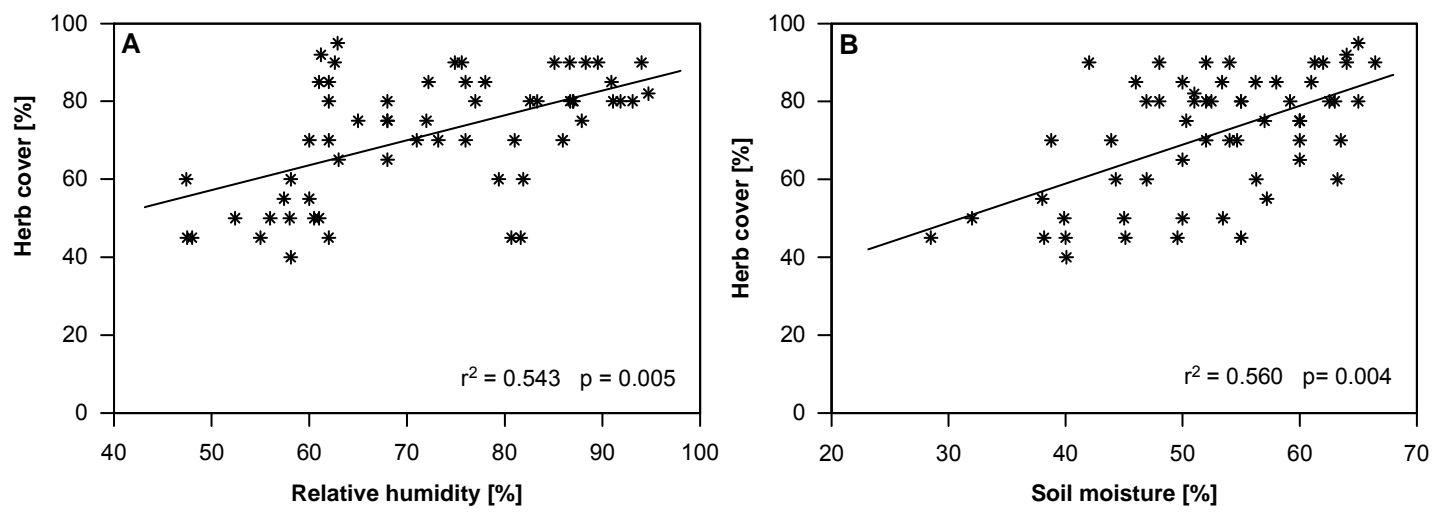

Fig. 3: Relationship between herb cover and air humidity (A), or soil moisture (B). Relative humidity was measured continuously and averaged over the day-time periods. Soil moisture refers to weekly measurements at $0-20 \mathrm{~cm}$. Significance was determined at $P \leq 0.05$.

The present investigation shows that for some species such as Anemone nemorosa, $A$. ranunculoides and Pulmonaria officinalis, soil moisture was more influential than air humidity. In contrast, other species such as Allium ursinum, Mercurialis perennis, Stachys sylvatica, and Impatiens noli-tangere, were more strongly influenced by air humidity than by soil moisture (Fig. 2, Table 3). Furthermore, total herb cover on the forest floor was positively affected by both air humidity and soil moisture (Table 3, Fig. $3)$. 
In a climate chamber experiment, LEUSCHNER (2002) showed that air humidity favors growth and vitality of temperate woodland herbs independently from soil moisture. In this experiment, six of eight species showed a decline in biomass production when they were grown under elevated levels of VPD. LENDZION \& LEUSCHNER (unpublished results) grew woodland herbs not only in climate chambers but also in open-top chambers on the forest floor which allowed to manipulate air humidity in the natural environment (see chapter 3). Two woodland herbs (Mercurialis perennis and Stachys sylvatica) growing in climate chambers in hydroponic culture showed a biomass decline of $40 \%$ when air humidity was reduced from $85 \%$ to $40 \%$. A decrease of $25 \%$ in biomass production occurred when the plants were grown in open-top chambers on the forest floor with an air humidity reduction of $15 \%$. The results of these studies further showed that the influence of air humidity on growth and development of woodland herb species existed independently from soil moisture status because the plants were grown in both experiments with non-limiting water supply. These findings together with the results of the present study suggest that the occurrence of woodland herbs in beech forests is closely related to both ample soil moisture supply and high air humidity.

In general, forests dominated by European beech are growing in oceanic to suboceanic climates where soil moisture is usually high, at least in spring and early summer, and VPD is low. Nevertheless, the relief may cause microclimatic and soil properties to vary considerably at local scale, thus leading to gradients in soil moisture and air humidity inside forests. This study shows that air humidity was indeed notably affected by the local topography. On south-facing slopes, air humidity was considerably lower than on north-facing slopes and in valleys. This result indicates that air humidity on the forest floor depends strongly on the aspect and inclination of a site. South-facing slopes receive $50 \%$ more radiation in spring than north-facing slopes despite a more or less closed beech canopy. Valley bottoms may experience a damped climate due to low wind velocities. On steep slopes, in particular at south-facing aspect, soils dry more rapidly than on level or north-facing sites, driven by higher radiation and higher wind speeds. However, soil moisture further depends on soil physical properties (texture and profile depth) and the access to water conducting soil layers, factors that do not directly affect air humidity. This explains why soil moisture and air humidity tend to vary independently from each other inside the forest. The complex combination of abiotic factors inside forest landscapes results in a mosaic of forest floor environments with either high air humidity and soil moisture, low air humidity and soil moisture, or high air humidity and low soil moisture or low air humidity and low soil moisture. In fact, all these combinations of the soil and atmospheric water status were observed in the 
study region. This indicates that air humidity and soil moisture were mostly acting independently from each other which was supported by the results of the CCA and the regression analysis.

Since $\mathrm{pH}$ values, exchangeable $\mathrm{Mg}$ and the $\mathrm{C} / \mathrm{N}$ ratio showed only minor differences between the micro-sites, no significant correlations between these factors and the distribution of woodland herbs were found. The concentration of exchangeable $\mathrm{K}$ or $\mathrm{Ca}$ influenced several species in addition to air humidity and soil moisture. However, the influence of soil chemistry may have been masked by soil moisture in certain cases. Soil moisture promotes the supply of nutrients to the roots. This is particularly important for those ions (such as $\mathrm{P}$ ) that have a low diffusivity in the soil solution. Thus, it may be that certain species may have preferred moist habitats (e.g., valley bottoms) not only because of higher soil moisture but also because of a better nutrient availability.

Although the canopy transmissivity for light has frequently been reported to be an important factor controlling herb distribution patterns (MARTENS et al. 2000, RANKIN \& TRAMER 2002, NORTH et al. 2005, JELASKA et al. 2006, GÁLHIDY et al. 2006), in this study, no strong correlation between measured PAR flux density and herb distribution patterns was detected. Because this study focused mainly on the influence of soil moisture and air humidity on species abundance, PAR was measured only at noon and no daily radiation courses were recorded which also cover light flecks. Certainly, daily and seasonal totals of radiation input should better correlate with species distribution than a limited number of measurements taken in spring and early summer. On the other hand, HÄRDTLE et al. (2003) suggested that light supply is less important than other environmental factors such as soil moisture in forests on moist, nutrient-rich soils. One may speculate that many species of the forest understory in moist and nutrientrich broad-leaved forests are dependent on the fertile soil condition and are well adapted to the low light supply conditions, or they complete their development cycle before the tree canopy is fully developed and therefore light would be less important for those species.

Besides a strong influence of abiotic factors such as soil moisture, soil chemistry, air humidity and light, biotic factors like dispersal ability, competition or herbivory can have a large effect on woodland species distribution. A characteristic feature of the herb layer in the Hordelymo-Fagetum beech forest community is a patchy distribution of certain species such as $A$. ursinum and $M$. perennis. For many species of this environment, vegetative dispersal by clonal growth and fragmentation is more important than sexual modes of propagation (DIERSCHKE \& SONG 1982, SCHMIDT et al. 1989). In addition, several studies have provided evidence that dispersal limitation may 
be an important factor structuring woodland herb communities (e.g., EHRLÉN \& ERIKSSON 2000, SVENNING \& SKOV 2002, TAKAHASHI \& KAMITANI 2004). However, the entire forest of the study region has the status of an ancient forest with a continuity of at least 200 years. Thus, dispersal limitation should have affected the different site types in the forest in a similar manner. The strong correlation between environmental factors and species distribution suggests that the soil and atmospheric moisture regimes together with abiotic factors are playing a dominant role in controlling the regional abundance of species in this forest while dispersal success may explain the absence of certain species on a finer spatial scale.

Some species of the present investigation were more abundant on sites with high soil moisture but lower air humidity (e.g., A. nemorosa, $P$. officinales), while others occurred more frequently on sites with both lower soil moisture and air humidity (e.g., Viola reichenbachiana, Galium odoratum). The reason for the latter behavior might be competition effects and not the preference of drier sites by these species. Under the dense carpets of $A$. ursinum or $M$. perennis, force competition for space and light is likely (EGGERT 1992). In fact, many of the facultative shade species of the forest floor environment are weak competitors for light that is easily suppressed by species with successful spread by clonal propagation (GRIME 1973, GEORGE \& BAZZAZ 1999, COSTA 2006). Some of the woodland flora species are probably less sensitive to soil drought and low air humidity. They might prefer sites with lower soil moisture and/or air humidity mainly because they are less closely populated, thereby avoiding competition. This study provided evidence that the abundance and distribution of several woodland species of beech forests depends on both soil moisture and air humidity, and that certain sensitive species may not occur at sites with low air humidity even when soil moisture is high. Therefore, air humidity must be regarded as an important abiotic factor that controls the abundance and distribution of woodland herbs together with soil moisture, light, soil chemistry and a number of biotic factors. 


\title{
Chapter 6
}

\author{
Synopsis
}

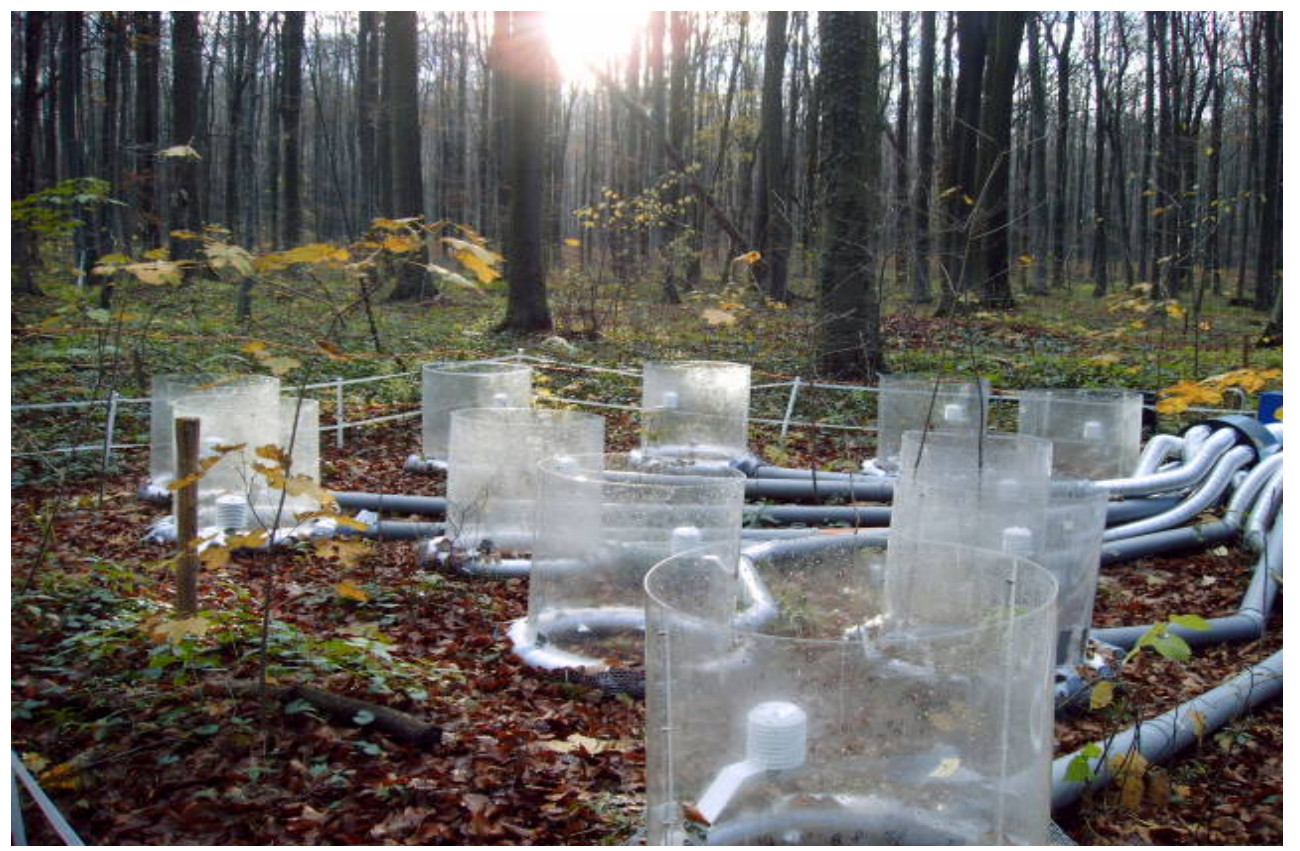




\section{Effects of air humidity on the growth and morphology of temperate woodland herbs and beech saplings}

In both climate chamber and open-top chamber experiments on the forest floor, the biomass production of temperate woodland herbs and beech saplings declined significantly when they were grown under lowered air humidity, but with ample soil moisture. A decrease in air humidity from $85 \%$ to $40 \%$ in the climate chamber experiment resulted in a decrease in dry matter production between $40 \%$ (woodland herbs, chapter 3 ) and $68 \%$ (beech saplings, chapter 4 ). In the open-top chamber experiment conducted on the forest floor, productivity declined by about $25 \%$ to $30 \%$ in all species after the atmospheric moisture was reduced by about $15 \%$. The results are in accordance with those of other studies which have found a lowered biomass production in economic and wild plants when air humidity was reduced (NIEMAN \& Poulsen 1967, GRANGe \& HAND 1987, MARSDEN et al. 1996, MORTENSEN \& GISLERÖD 2000, ROBERTS \& ZWIAZEK 2001, LEUSCHNER 2002, CODARIN et al. 2006).

Changes in biomass allocation under conditions of reduced air humidity could be one possible reason for observed decreases in growth rates. For example, several conifers have shown decreased carbon allocation to shoots when grown under reduced air humidity (MARSDEN et al. 1996, DARLINGTON 1997). Any decrease in carbon allocation to photosynthetic tissues is likely to lead to decreases in growth (CUNNINGHAM 2006). However, in this investigation, both above- and below-ground biomass decreased simultaneously with decreasing air humidity, and therefore, root/shoot ratio showed no significant differences between the treatments in all three species and both experimental setups. Likewise, other studies have reported no changes in the root/shoot ratio in herb and tree species that were grown under different air humidity levels (LEUSCHNER 2002, WERNEYER 2003, CUNNINGHAM 2006). In contrast, MORTENSEN et al. (2001) found an increase in the root/shoot ratio in roses when they were grown under lowered atmospheric moisture. The present study provides evidence that contrasting air humidity levels seem to have no influence on root/shoot carbon allocation patterns. 
Table 1: Direction of change of biomass production, root/shoot ratio, total leaf area, average leaf size, number of leaves and number of buds of two woodland herbs and of beech saplings when grown under reduced air humidity in climate chambers or in open-top chambers on the forest floor. $\downarrow$ decrease, $\uparrow$ increase, $=$ no change.

\begin{tabular}{|c|c|c|c|c|c|c|}
\hline & $\begin{array}{l}\text { Biomass } \\
\text { production }\end{array}$ & $\begin{array}{l}\text { Root/shoot } \\
\text { ratio }\end{array}$ & $\begin{array}{c}\text { Total leaf } \\
\text { area }\end{array}$ & $\begin{array}{l}\text { Average } \\
\text { leaf size }\end{array}$ & $\begin{array}{c}\text { Number of } \\
\text { leaves }\end{array}$ & $\begin{array}{l}\text { Number } \\
\text { of buds }\end{array}$ \\
\hline \multicolumn{7}{|c|}{ Climate chamber } \\
\hline M. perennis & $\downarrow$ & $=$ & $\downarrow$ & $=$ & $\downarrow$ & $=$ \\
\hline S. sylvatica & $\downarrow$ & $=$ & $\downarrow$ & $=$ & $\downarrow$ & $=$ \\
\hline F. sylvatica & $\downarrow$ & $=$ & $\downarrow$ & $\downarrow$ & $\downarrow$ & $\downarrow$ \\
\hline \multicolumn{7}{|c|}{ Open-top chamber } \\
\hline M. perennis & $\downarrow$ & $=$ & $\downarrow$ & $\downarrow$ & $=$ & $\downarrow$ \\
\hline S. sylvatica & $\downarrow$ & $=$ & $\downarrow$ & $\downarrow$ & $=$ & $\downarrow$ \\
\hline F. sylvatica & $\downarrow$ & $=$ & $\downarrow$ & $=$ & $\downarrow$ & $\downarrow$ \\
\hline
\end{tabular}

In both experiments and in all three investigated species, the reduction of biomass in the drier treatments was closely associated with a leaf area reduction (Table 1). Interestingly, the reduction of leaf area in the dry-air treatments had different causes in the species and the experiments. In the climate chamber experiment, the leaf area reduction of the two woodland herb species was mainly due to a smaller number of leaves produced in the drier treatments, while average leaf size was not altered significantly. In contrast, in the open-top chamber experiment, the leaf area reduction of the woodland herb species was mainly caused by a reduced average leaf size and not by a lowered leaf number. In the beech saplings, the leaf area reduction in the climate chamber experiment was a result of both, a reduced average leaf size and leaf number, while in the open-top chamber experiment, a significantly lowered number of leaves caused the leaf area reduction. The different results between the two experiments could be due to the different experimental conditions (climate chamber: hydroponic culture, optimal nutrient supply; open-top chamber: natural forest soil, soil water near field capacity, no additional nutrient supply). While water supply in the two experimental designs was optimal, the differences in leaf growth could be due to the difference in nutrient supply. Indeed, mineral nutrition is known to influence leaf growth (e.g., OISHI 1991, SNIR \& NEUMANN 1997, JOVANOVIC 2004, Vos et al. 2005). Furthermore, increased resource availability has been found to support the production of more leaves (BAZZAZ \& HARPER 1977, STEER \& HOCKING 1983), which would explain the higher leaf number observed in the two woodland herbs species in the climate chamber experiment. However, contrasting nutrient supply rate could explain why the leaf area reduction in the two woodland herbs was either due to a reduced number of leaves (climate chamber experiment) or a reduced average leaf size (open-top chamber experiment). It would not explain the different observations in beech, where, 
for example, the average leaf size was insensitive to VPD in the open-top chamber experiment. On the other hand, the differences between the woodland herb species and the beech saplings could simply be due to the different growth forms.

The results of the two experiments and the two different plant life forms were consistent in showing that air humidity acts as a soil water-independent growth factor for wild plants.

\section{What causes the negative effect of lowered air humidity on growth and leaf development?}

Different causal chains between air humidity and plant growth are possible which could explain the observed biomass reduction under low air humidity. First, low atmospheric moisture could induce partial stomatal closure, thereby limiting carbon assimilation (reduced carbon gain hypothesis). Second, low air humidity could negatively influence leaf growth through a higher transpirative water loss and a lower turgor in the growing leaf, thus reducing the division or elongation of the meristematic cells (leaf growth limitation hypothesis).

This study provides evidence in support of the leaf growth limitation hypothesis, but not of the reduced carbon gain hypothesis. While leaf conductance in the three investigated species declined with decreasing atmospheric moisture, the light-saturated net photosynthesis rate was not reduced in plants of the dry-air treatment (LENDZION, unpublished data). Moreover, the reduction in leaf area in the reduced-humidity treatments was as large as the reduction in dry matter production (or even exceeded it), in all three species and both experiments. This indicates that the reduction in leaf conductance had only a small or no effect on the rate of carbon assimilation in the treatments with decreased atmospheric moisture. To explain why root growth declined additionally under reduced air humidity, leaving the root/shoot ratio unaffected by low air humidity, further experiments are necessary.

Table 2: Direction of change in leaf water potential, leaf turgor, leaf conductance, leaf transpiration rate and leaf water content of the two woodland herbs and beech saplings when they were grown under reduced air humidity in climate chambers or on the forest floor in opentop chambers. $\downarrow$ decrease, $\uparrow$ increase.

\begin{tabular}{lccccc}
\hline & $\begin{array}{c}\text { Leaf water } \\
\text { potential }\end{array}$ & Leaf turgor & $\begin{array}{c}\text { Leaf } \\
\text { conductance }\end{array}$ & $\begin{array}{c}\text { Leaf } \\
\text { transpiration } \\
\text { rate }\end{array}$ & $\begin{array}{c}\text { Leaf water } \\
\text { content }\end{array}$ \\
M. perennis & $\downarrow$ & n.d. & $\downarrow$ & $\uparrow$ & $\downarrow$ \\
S. sylvatica & $\downarrow$ & n.d. & $\downarrow$ & $\uparrow$ & $\downarrow$ \\
F. sylvatica & $\downarrow$ & $\downarrow$ & $\downarrow$ & $\uparrow$ & $\downarrow$ \\
\hline
\end{tabular}


This study shows that leaf growth was dramatically limited under low air humidity as discussed in chapter 3 and chapter 4 . This reduction was due to a limited initiation of leaf buds or a reduced leaf expansion rate.

What causes the leaf growth reduction under low air humidity conditions? Increased transpiration rates under low air humidity have been found to decrease cell turgor pressure, thereby causing a decrease in leaf expansion (FRENSCH \& SCHULZE 1988, Ben HaJ SALAH \& TARDIEU 1996, ClifTON-BRown \& JONES 1999). Some authors have reported that even small reductions in leaf turgor and leaf water potential were sufficient to reduce leaf expansion significantly (ACEVEDO et al. 1971, DALE 1988, SERPE \& MATTHEWS 2000). In this study, leaf transpiration rate increased with decreasing air humidity in the two woodland herb species and in the beech saplings. Furthermore, the transpirative water loss was linked to decreased leaf water content, lowered leaf water potentials, and reduced leaf turgor (Table 2). Direct soil waterindependent effects of the atmospheric water status on leaf turgor and leaf water potentials, as indicated in the present study, have also been reported in studies with other dicots (FRENSCH 1997, SERPE \& MATTHEWS 2000).

As described above, reduced leaf expansion during water depletion can be a consequence of lowered water potential and decreased turgor (KRAMER 1988, GOWING et al. 1990, PASSIOURA \& FREY 1992, PASSIOURA 1994, FRENSCH 1997, HSIAO et al. 1998, MUNNS et al. 2000, SERPE \& MATTHEWS 2000), but reduced leaf expansion can also be due to elevated abscisic acid (ABA) concentrations (ZHANG \& DAVIES 1990a,b, DODD \& DAVIES 1996, ALVES \& SETTER 2000), or by a combination of both parameters (e.g., TARDIEU \& DAVIES 1992, TARDIEU et al. 1993, THOMPSON et al. 1997). The same parameters are also known to limit the initiation of leaf buds (DAVIES \& ZHANG 1991, DAVIES et al. 1993, LÖSCH 2003).

While the role of $A B A$ on leaf development in plants under soil water depletion has been studied extensively (e.g., ZHANG \& DAVIES 1990a,b, DODD \& DAVIES 1996, ALVES $\&$ SETTER 2000), there is less information about its role on leaf development under contrasting air humidity levels but ample soil moisture conditions. In a study by LENDZION (unpublished), two woodland herb species (Stachys sylvatica, Lamiastrum galeobdolon) showed significantly higher ABA concentrations in the leaves when air humidity was reduced by about $40 \%$. The elevated ABA concentrations in the leaves were correlated with decreased leaf growth rates in the plants that were grown under low air humidity and unlimited water supply. Thus, it is likely that leaf growth in this study was reduced because of lowered leaf water potential and leaf turgor in addition to the elevated ABA levels. 
The present study showed that lowered air humidity significantly affects the initiation of leaf buds and leaf extension, the two processes that determine leaf area development in plants. The causes of plant growth reduction under conditions of decreased air humidity are complex, making more detailed analyses needed that include the components of leaf elongation rate, leaf photosynthetic activity, and leaf ABA levels. Such a causal analysis must also address indirect effects of atmospheric moisture on plant growth, such as altered foliar nutrient levels.

\section{Is air humidity an important abiotic site factor for the forest floor vegetation?}

By linking climate chamber to field manipulation experiments, this study shows clearly that the prevailing air humidity acts as a soil water-independent growth factor for the forest floor vegetation. The results of the climate chamber and open-top chamber experiments are supported by a field study in a Central European beech forest (chapter 5 ), in which the distribution of several woodland herb species was correlated with the air humidity regime.

It is well known that the distribution of forest herbs depends on soil moisture (POULSEN 1996, NORTH et al. 2005, GÁlHIDY et al. 2006, HOKKANEN 2006, chapter 5). However, the results of my experiments with different air humidity levels have shown that low air humidity can produce stress in woodland herbs and tree saplings independently from the status of soil moisture. This may be important in habitats where soil moisture is high but air humidity low. The field study has shown that soil moisture and air humidity can vary independently from each other on the forest floor. For example, in open valley bottoms with a less closed canopy, soil moisture is often high but air humidity can be low due to higher radiation and stronger air turbulence. Hence, the spatial distribution of the species of the forest floor vegetation is often influenced by soil moisture, but depends also on the prevailing air humidity.

So far, the importance of air humidity for forest floor vegetation in temperate forests has been widely neglected. Studies dealing with the distribution of forest understory plants have concentrated on the effects of soil moisture (POULSEN 1996, NORTH et al. 2005, GÁLHIDY et al. 2006, HOKKANEN 2006), soil chemistry (SVENNING \& SKOV 2002, NORTH et al. 2005), light regimes (MARTENS et al. 2000, RANKIN \& TRAMER 2002, JELASKA et al. 2006, GÁLHIDY et al. 2006), and biotic factors (EHRLÉN \& ERIKSSON 2000, SVENNING \& SKOV 2002, TAKAHASHI \& KAMITANI 2004).

While the forest floor environment is characterized by intense shade, many authors have concluded that the low light input is the most important factor for the forest understory. The characteristic morphology of woodland herbs has been assumed to be 
a consequence of low light input. However, in shaded habitats, not only light input is reduced but also air humidity is higher than in open habitats. Thus, air humidity could also be responsible for the characteristic growth forms of woodland herbs. In a associated study by WITTICH (2007) temperate woodland herb species were grown in a gap in open-top chambers with manipulated air humidity and light supply in order to investigate whether reduced light supply and high air humidity (the two component factors of shade) are responsible for the morphology of forest herbs. The results of her study have shown that all species grew better in chambers without light reduction than in shaded chambers but only when air humidity was high. WITTICH (2007) has therefore suggested that woodland herbs may have adapted to shade, but their characteristic adaptations are based on high air humidity and not on low light intensities, and that this flora consequently depends more on high air humidity than on low light supply. The results of her study provide further support for the importance of air humidity as a site factor for the forest floor vegetation as was shown in the present study.

How will the species of the forest floor environment respond if air humidity is lowered during gap formation, clear-cutting or under a drier climate?

\section{Temperate woodland herbs}

This study showed that woodland herbs require sufficiently high air humidity levels for optimal growth and that the distribution of several species is determined by air humidity. The creation of gaps by human activities or natural disturbances alters the microclimate on the forest floor (BROSOFSKE et al. 1997, CHEN et al. 1999). For example, as more sunlight reaches the forest floor, temperature increases, and soil moisture and air humidity decrease. The results of the present study indicate that gap formation and clear-cutting of forests will threaten the vitality and survival of woodland herbs not only by exposing them to excess light, heat stress, and reduced soil water availability, but also through lowered air humidity. A drier climate with longer and more intense summer droughts is likely to have negative consequences for several woodland herb species.

\section{European beech}

European beech is the most important broad-leaved tree species in Central and Western Europe and is known for its sensitivity to drought (ELLENBERG 1996, BACKES \& LEUSCHNER 2000). Since several studies have reported a strong negative effect of soil drought on growth and survival of beech saplings (e.g., KOZLOWSKI \& PALLARDY 1997, LEBOURGEOIS et al. 1998, FotelLI et al. 2000, MEIER 2007), there is an ongoing discussion about how beech will survive a drier climate in the future (RENNENBERG et 
al. 2004, AMmER et al. 2005) and how silviculture can be optimized to guarantee beech survival under a changed climate (FOTELLI 2002, CZAJKOWSKI et al. 2005). However, no study has investigated the effects of lowered air humidity. The results of the present study show that the growth and survival of beech depends strongly on the prevailing air humidity and that lowered air humidity can dramatically influence beech survival, even under ample soil moisture (chapter 4). Therefore, possible negative responses of beech to a drier climate will be more pronounced than so far suspected because beech is not only sensitive to soil drought but also to lowered air humidity. A combination of both soil moisture reduction and lowered air humidity should therefore have strong negative effects on beech and might limit beech distribution in the drier parts of Europe.

\section{Conclusions}

The results of the present study show that air humidity is an important, soil moisture independent growth and site factor for the forest floor vegetation of Central European beech forests. Low atmospheric moisture can produce drought stress in woodland herbs and tree saplings, even though soil moisture is not limiting. Woodland herbs and tree saplings require for optimal growth and development sufficiently high air humidity. A decrease of air humidity as a result of gap formation, clear-cutting of forests, or in a drier climate with longer and more intense summer droughts might strongly threaten species of the forest floor vegetation. 
References 


\section{References}

ACEVEDO, E, HSIAO, TC \& DW HENDERSON. 1971. Immediate and subsequent growth responses of maize leaves to changes in water status. Plant Physiology 48: 631636.

AHLGREN, CE \& IF AHLGREN. 1981. Some effects of different forest litters on seed germination and growth. Canadian Journal of Forest Research 11: 710-714.

ALVES, AAC \& TL SETTER. 2000. Response of cassava to water deficit: leaf area growth and abscisic acid. Crop Science 40: 131-137.

Ammer, C, Albrecht, L, Borchert, H, Brosinger, F, Dittmar, C, Elling, W, EWald, J, Felbermeier, B, von Gilsa, H, Huss, J, Kenk, J, Kölling, C, Kohle, U, Meyer, P, Mosandl, R, Moosmayer, HU, Palmer, S, Reif, A, Rehfues, KE \& B Stimm. 2005. Zur Zukunft der Buche (Fagus sylvatica L.) in Mitteleuropa- kritische Anmerkungen zu einem Beitrag von Rennenberg et al. (2004). Allgemeine Forst- und Jagdzeitschrift 176: 60-67.

ANDERSSON, ME 1993. Aluminium toxicity as a factor limiting the distribution of Allium ursinum L. Annals of Botany 72: 607-611.

APHALO, PJ \& PG JARVIS. 1991. Do stomata respond to relative humidity? Plant, Cell and Environment 14: 127-132.

ARANDA, I, GIL, L \& J PARDOS. 1996. Seasonal water relations of three broadleaved species (Fagus sylvatica L., Quercus petraea (Mattuschka) Liebl. and Quercus pyrenaica Willd.) in a mixed stand in the centre of the Iberian Peninsula. Forest Ecology and Management 84: 219-221.

ARNDT, SK, ClifFord, SC, WANEK, W, JONES, HG \& M POPP. 2001. Physiological and morphological adaptions of the fruit tree Ziziphus rotundifolia in response to progressive drought stress. Tree Physiology 21: 705-715.

ASPELMEIER, S \& C LEUSCHNER. 2006. Genotypic variation in drought response of silver birch (Betula pendula Roth): leaf and root morphology and carbon partitioning. Trees 20: 42-52.

BACKES, K. 1996. Der Wasserhaushalt vier verschiedener Baumarten der Heide-WaldSukzession. PhD thesis, University of Göttingen.

BACKES, K \& C LEUSCHNER. 2000. Leaf water relations of competitive Fagus sylvatica and Quercus petraea trees during 4 years differing in soil drought. Canadian Journal of Forest Research 30: 335-346.

BALL, MC \& GD FARQUHAR. 1984. Photosynthetic and stomatal responses of two mangrove species, Aegiceras corniculatum and Avicennia marina, to long term salinity and humidity conditions. Plant Physiology 74: 1-6. 
BALL, MC, COCHRANE, MJ \& HM RAWSON. 1997. Growth and water use of the mangroves Rhizophora apiculata and $R$. stylosa in response to salinity and humidity under ambient and elevated concentrations of atmospheric $\mathrm{CO}_{2}$. Plant, Cell and Environment 20: 1158-1166.

BAumeister, W \& W ERNST. 1978. Mineralstoffe und Pflanzenwachstum. Fischer Verlag, Stuttgart.

BAZZAZ, FA \& JL HARPER. 1977. Demographic analysis of the growth of Linum usitatissimum. New Phytologist 78: 193-208.

BEATTY, SW. 1984. Influence of microtopography and canopy species on spatial patterns of forest understory plants. Ecology 65: 1406-1419.

BECKER, M, NiEMINEN, TM \& F GeREMIA. 1994. Short-term variations and long-term changes in oak productivity in northeastern France. The role of climate and atmospheric $\mathrm{CO}_{2}$. Annals of Forest Science 51: 477-492.

BENECKE, P. 1982. Wasserhaushalt von Wäldern auf flachgründigen Standorten (Kalkbuchenwälder). Arbeitsberichte 1981/1982 aus dem Sonderforschungsbereich 135 - Ökosysteme auf Kalkstein - an der Georg-August-Universität Göttingen, pp. 221- 258.

Ben HaJ Salah, H \& F TARDieu. 1996. Quantitative analysis of the combined effects of temperature, evaporative demand and light on leaf elongation rate in well-watered field and laboratory-grown maize plants. Journal of Experimental Botany 47: 16891698.

Beyschlag, W, Pfanz, H \& RJ RYel. 1992. Stomatal patchiness in Mediterranean evergreen species. Phenomenology and consequences for the interaction of midday depression in photosynthesis and transpiration. Planta 187: 546-553

BogNER, W. 1966. Experimentelle Prüfung von Waldbodenpflanzen auf ihre Ansprüche an die Form der Stickstoffernährung. PhD thesis, University of Stuttgart-Hohenheim.

BOLTE, A \& A RolofF. 1993. Einfluss von Buchenüberhältern auf Bodenvegetation und Naturverjüngung. Allgemeine Forst und Jagdzeitung 164: 97-102.

BONGARTEN, BC \& RO TESKEY. 1987. Dry weight partitioning and its relationship to productivity in Loblolly pine seedlings from seven sources. Forest Science 33: 255267.

BRADFORD, KJ \& TC HSIAO. 1982. Stomatal behaviour and water relations of waterlogged tomato plants. Plant Physiology 70: 1508-1513.

BRAFIELD, EG \& CG GUTTRIDGE. 1984. Effects of night-time humidity and nutrient solution concentration on the calcium content of tomato fruit. Scientia Horticulturae 22: 207-217. 
BRATTON, SP. 1976. Resource division in an understory herb community: responses to temporal and microtopographic gradients. American Naturalist 110: 679-693.

BRAUN, S \& W FLÜCKIGER. 1987. Untersuchungen an Gipfeltrieben von Buche (Fagus sylvatica L.). Botanica Helvetica 97: 61-73.

Brosofske, KD, CHEN, J, NAIMAN, RJ \& JF FRANKLIN. 1997. Harvesting effects on microclimate gradients from small streams to upland in western Washington. Ecological Applications 7: 1188-1200.

BUCKLEY, DS, SHARIK, TL \& JG ISEBRANDS. 1998. Regeneration of northern red oak: positive and negative effects of competitor removal. Ecology 79: 65-78.

BUNCE, JA. 1996. Does transpiration control stomatal respones to water vapour pressure deficit? Plant, Cell and Environment 19: 131-135.

BUNCE, JA. 2006. How do leaf hydraulics limit stomatal conductance at high water vapour pressure deficits? Plant, Cell and Environment 29: 1644-1650.

CHEN, J, SAUnders, SC, CROW, TR, NAIMANN, RJ \& KD BROSOFSKE. 1999. Microclimate in forest ecosystem and landscape ecology. Bioscience 49: 288-297.

CLIFTON-BROWN, JC \& MB JONES. 1999. Alternation of transpiration rate, by changing air vapour pressure deficit, influences leaf extension rate transiently in Miscanthus. Journal of Experimental Botany 50: 1393-1401.

Codarin, S, Galopin, G \& G Chasseriaux. 2006. Effect of air humidity on the growth and morphology of Hydrangea macrophylla L. Scienta Horticulturae 108: 303-309.

Collatz, GL, Ball, JT, Grivet, C \& JA BerRy. 1991. Physiological and environmental regulation of stomatal conductance, photosynthesis and transpiration: a model that includes boundary layer. Agricultural and Forest Meteorology 54: 107-136.

COLLIER, GF \& TW TIBBITTS. 1984. Effects of relative humidity and root temperature on calcium concentration and tipburn development in lettuce. Journal of the American Society for Horticultural Science 109: 128-131.

COSTA, FR, MAGNUSSON, WE \& RC LUIZAO. 2006. Mesoscale distribution patterns of Amazonian understorey herbs in relation to topography, soil and watersheds. Journal of Ecology 93: 863-878.

COWAN, IR. 1994. As to the mode of action of guard cells in dry air. In: SCHULZE, ED \& MM CALDWELL (eds.). Ecophysiology of Photosynthesis. Springer Verlag, New York, pp. 205-229.

CUNNINGHAM, SC. 2006. Effect of vapour pressure deficit on growth of temperate and tropical evergreen rainforest trees of Australia. Acta Oecologia 30: 399-406.

CZAJKOWSKI, T \& A BOLTE. 2005. Unterschiedliche Reaktion deutscher und polnischer Herkünfte der Buche (Fagus sylvatica L.) auf Trockenheit. Allgemeine Forst- und Jagdzeitschrift 177: 30-40. 
CZAJKOWSKI, T, KÜHLING, M \& A BOLTE. 2005. Einfluss der Sommertrockenheit im Jahre 2003 auf das Wachstum der Buche (Fagus sylvatica L.) im nordöstlichen Mitteleuropa. Allgemeine Forst- und Jagdzeitschrift 176: 133-143.

CZAJKOWSKI, T, KOMPA, T \& A BOLTE. 2006. Zur Verbreitungsgrenze der Buche (Fagus sylvatica L.) im nordöstlichen Mitteleuropa. Forstarchiv 77: 203-216.

DAI, Z, EDWARDS, GE \& MSB KU. 1992. Control of photosynthesis and stomatal conductance in Ricinus communis L. (castor bean) by leaf air vapour pressure deficit. Plant Physiology 99: 1426-1434.

DALE, JE. 1988. The control of leaf expansion. Annual Review of Plant Physiology 39: 267-295.

DARLINGTON, AB, HALINSKA, A, DAT, JF \& TJ BLAKE. 1997. Effects of increasing saturation deficit on growth and $A B A$ levels in black spruce and jack pine. Trees 11: 223-228.

DAVIES, WJ \& J ZHANG. 1991. Root signals and the regulation of growth and development of plants in drying soil. Annual Review of Plant Physiology and Molecular Biology 42: 55-76.

Davies, WJ, TARdieu, F \& CL TREJo. 1993. Chemical signalling and the adaption of plants to conditions where water availability is restricted. In: FOWDEN, L, MANSFELD, T \& J STOdDART (eds.). Plant adaption to environmental stress. Chapman \& Hall, London-Glasgow-New York, pp. 209-222.

DIERSCHKE, H \& Y SONG. 1982. Vegetationsgliederung und kleinräumige Horizontalstruktur eines submontanen Kalkbuchenwaldes. In: DiERSCHKE, H (ed.). Struktur und Dynamik von Wäldern. Berichte der Internationalen Symposien der Internationalen Vereinigung für Vegetationskunde 25, Rinteln, pp. 513-539.

DIERSCHKE, H. 1989. Kleinräumige Vegetationsstruktur und phänologischer Rhytmus eines Kalkbuchenwaldes. Verhandlungen der Gesellschaft für Ökologie 17: 131 143.

DODD, IC \& WJ DAVIES. 1996. The relationship between leaf growth and ABA accumulation in grass leaf elongation zone. Plant, Cell and Environment 19: 10471056.

EBER, W. 1972. Über das Lichtklima von Wäldern bei Göttingen und seinen Einfluss auf die Bodenvegetation. PhD thesis, University of Göttingen.

EEA (European Agency). 2004. Impacts of Europe's changing climate. Copenhagen.

EGGERT, A. 1985. Zur Ökologie der Krautschichtvegetation in einem BärlauchKalkbuchenwald. PhD thesis, University of Göttingen.

EGGERT, A. 1992. Dry matter economy and reproduction of temperate forest spring geophyte, Allium ursinum. Ecography 15: 45-55. 
EHRHARDT, O. 1988. Der Strahlungshaushalt eines Buchenwaldes und dessen Abwandlung während der verschiedenen phänologischen Entwicklungsphasen. Berichte des Forschungszentrums Waldökosysteme. Reihe A. Band 45. Selbstverlag des Forschungszentrums Waldökosysteme der Universität Göttingen.

EHRLÉN, J \& O ERIKSSON. 2000. Dispersal limitation and patchy occupancy in forest herbs. Ecology 81: 1667-1674.

ELLENBERG, H. 1939. Über Zusammensetzung, Standort und Stoffproduktion bodenfeuchter Eichen- und Buchen-Mischwaldgesellschaften NordwestDeutschlands. Mitteilungen der Floristisch-Soziologischen Arbeitsgemeinschaft Niedersachsen 5: 3-135.

ELLENBERG, H. 1996. Vegetation Mitteleuropas mit den Alpen. Ulmer Verlag, Stuttgart.

ERICE, G, ARANJUELO, I, IRIGOYEN, JJ \& M SANCHEZ-DiAZ. 2007. Effect of elevated $\mathrm{CO}_{2}$, temperature and limited water supply on antioxidant status during regrowth of nodulated alfalfa. Physiologia Plantarum 130: 33-45.

ERIKSSON, O. 1995. Seedling recruitment in deciduous forest herbs: the effects of litter, soil chemistry and seed bank. Flora 190: 65-70.

ERLANDSSON, G. 1975. Rapid effects on ion and water uptake induced by changes of water potential in young wheat plants. Physiologia Plantarum 35: 256-262.

EWALD, J. 1999. Relationships between floristic and microsite variability in coniferous forests of the Bavarian Alps. Phytocoenologia 29: 327-344.

FACELLI, JM \& STM PICKETT. 1991a. Plant litter: its dynamics and effects on plant community structure. Botanical Review 57: 1-32.

FACELLI, JM \& STM PICKETT. 1991b. Plant litter: light interception and effects on an old field plant community. Ecology 57: 1024-1033.

FALKENGREN-GRERUP, U \& G TYLER. 1993. Experimental evidence for the relative sensitivity of deciduous forest plants to high soil acidity. Forest Ecology and Management 60: 311-326.

FARQUHAR, GD. 1978. Feedforward responses of stomata to humidity. Australian Journal of Plant Physiology 7: 787-800.

FISCHER, W. 1981. Das Auftreten von Allium ursinum L. in Brandenburg. Gleditschia 8: 121-127.

FLEMMING, G. 1982. Wald, Wetter, Klima. Einführung in die Forstmeteorologie. VEB Deutscher Landwirtschaftsverlag, Berlin.

FORD, MA \& GN THORNE. 1974. Effects of atmospheric humidity on plant growth. Annals of Botany 38: 441-452.

Fotelli, MN, RADOGLOU, KM \& HIA CONSTANTINIDOU. 2000. Water stress responses of seedlings of four Mediterranean oak species. Tree Physiology 20: 1065-1075. 
Fotelli, mN, Gessler, A, Peuke, AD \& H Rennenberg. 2001. Drought affects the competitive interaction between Fagus sylvatica seedlings and an early successional species, Rubus fruticosus: responses of growth, water status and $\delta^{13} \mathrm{C}$ composition. New Phytologist 151: 427-435.

FOTELLI, MN. 2002. Effects of climate change and forest management on the water and nitrogen status of European beech regeneration and understorey vegetation. PhD thesis, University of Freiburg.

Fotelli, mN, Rennenberg, H, Holst, T, Mayer, H \& A Gessler. 2003. Effects of climate and silviculture on the carbon isotope composition of understorey species in beech (Fagus sylvatica L.) forest. New Phytologist 159: 229-244.

Fotelli, MN, Rienks, M, Rennenberg, H \& A Gessler. 2004. Climate and forest managment affect $15 \mathrm{~N}$-uptake, $\mathrm{N}$ balance and biomass of European beech (Fagus sylvatica L.) seedlings. Trees 18: 157-166.

FRANKS, PJ, COWEN, IR \& GD FARQUHAR. 1997. The apparent feed-forward response of stomata to air vapour pressure deficit: information revealed by different experimental procedures with two rainforest trees. Plant, Cell and Environment 20: 142-145.

FRANKS, PJ \& GD FARQUHAR. 1999. A relationship between humidity response, growth form and photosynthetic operating point in $\mathrm{C}_{3}$ plants. Plant, Cell and Environment 22: $1337-1349$.

FRECH, A. 2006. Walddynamik in Mischwäldern des Nationalpark Hainich. Untersuchung der Mechanismen und Prognose der Waldentwicklung. PhD thesis, University of Göttingen.

FRENSCH, J \& ED SCHULZE. 1988. The effect of humidity and light on cellular water relations and diffusion conductance of leaves of Tradescantia virginiana L. Planta 173: $554-562$.

FRENSCH, J. 1997. Primary response of root and leaf elongation to water deficits in the atmosphere and soil solution. Journal of Experimental Botany 48: 985-999.

GAFFNEY, JJ. 1978. Humidity: basic principles and measurement techniques. Advances in Horticultural Science 13: 551-555.

GALE, J \& RM HAGAN. 1966. Plant antitranspirants. Annual Review of Plant Physiology 17: 269-282.

GÁLHIDY, L, MIHÓK, B, HAGYÓ, A, RAJKAJ, K \& T STANDOVÁR. 2006. Effects of gap size and associated changes in light and soil moisture on the understorey vegetation of a Hungarian beech forest. Plant Ecology 183: 133-145.

Geiger, R, ARON, RH \& P TODHUNTER. 1995. The climate near the ground. Vieweg, Braunschweig, Wiesbaden. 
GeORGE, LO \& FA BAZZAZ. 1999. The pteridophyte understory as an ecological filter: Emergence and establishment of canopy-tree seedlings. Ecology 80: 833-845.

Gessler, A, Schrempp, S, Matzarakis, A, Mayer, H, Rennenberg, H \& MA Adams. 2001. Radiation modifies the effect of water availability on the carbon isotype composition of beech (Fagus sylvatica). New Phytologist 150: 653-664.

Gessler, A, Keitel, C, NAHM, M \& H RenNenBeRg. 2004. Water shortage affects the water and nitrogen balance in central European beech forests. Plant Biology 6: 289298.

Gessler, A, Keitel, C, KreuzWieser, J, Matyssek, R, Seiler, W \& H Rennenberg. 2007. Potential risk for European beech (Fagus sylvatica L.) in a changing climate. Trees 21: 1-11.

Ghorbani, R, Seel, W, Rashed, MH \& C Leifert. 2006. Effect of plant age, temperature and humidity on virulence of Ascochyta caulina on common lambsquarters (Chenopodium album). Weed Science 54: 526-531.

GisleRÖD, HR, SELMER-Olsen, AR \& LM MORTENSEN. 1987. The effect of air humidity on nutrient uptake of some greenhouse plants. Plant and Soil 102: 193-196.

GISLERÖD, HR \& LM MORTENSEN. 1990. Relative humidity and nutrient concentration affect nutrient uptake and growth of Begonia hiemalis. Advances in Horticultural Science 25: 524-526.

GOWER, ST, VOGT, KA \& CC GRIER. 1992. Carbon dynamics of the Rocky Mountain Douglas fir: influence of water and nutrient availability. Ecological Monographs 62: 43-65.

GOWING, DJG, DAVIES, WJ \& HG JONES. 1990. A positive root sourced signal as an indicator of soil drying in apple, Malus $\mathrm{x}$ domestica Borkh. Journal of Experimental Botany 41: 1535-1540.

GOWING, DJG, JONES, HG \& WJ DAVIES. 1993. Xylem-transported abscisic acid: the relative importance of its mass and its concentration in the control of stomatal aperture. Plant, Cell and Environment 16: 453-459.

GRAAE, BJ \& VS HESKJAER. 1997. A comparison of understorey vegetation between untouched and managed deciduous forest in Denmark. Forest Ecology and Management 96: 111-123.

GRANGE, RI \& DW HAND. 1987. A review of the effects of atmospheric humidity on the growth of horticultural crops. Journal of Horticultural Science 62: 125-134.

GRANier, A, BIRON, P \& D LEMOINE. 2000. Water balance, transpiration and canopy conductance in two beech stands. Agricultural and Forest Meteorology 100: 291308. 
GrANTZ, DA. 1990. Plant response to atmospheric humidity. Plant, Cell and Environment 13: 667-669.

GRANTZ, DA \& FC MEINZER. 1990. Stomatal response to humidity in a sugar field: simultaneous porometric and micro-meteorological measurements. Plant, Cell and Environment 13: 27-37.

GRAY, AN \& TA SPIES. 1992. Use of Time Domain Reflectometry (TDR) to determine water content of mineral and organic substrates in conifer canopy gaps. Bulletin of the Ecological Society of America 73: 191-192.

GREgory, JM, MitCheLL, JFB \& AJ BRADY. 1997. Summer drought in northern midlatitudes in a time-dependent $\mathrm{CO}_{2}$ climate experiment. Journal of Climate 10: 662-686.

GRIME, JP. 1973. Competitive exclusion in herbaceous vegetation. Nature 242: 344347.

HALL, JB \& MD SWAINE. 1976. Classification and ecology of closed-canopy tropical forest in Ghana. Journal of Ecology 64: 913-951.

HALL, JB \& MD SWAINE. 1981. Distribution and Ecology of Vascular Plants in a Tropical Rain Forest. Forest Vegetation in Ghana. Geobotany Volume 1. Junk, The HaqueBoston-London.

Hamilton, JG, Delucia, EH, George, K, Naidu, SL, Finzi, AC \& WH Schlesinger. 2002. Forest carbon balance under elevated $\mathrm{CO}_{2}$. Oecologia 131: 250-260.

HÄrdtLe, W, Von OheimB, G \& C WestPhal. 2003. The effects of light and soil conditions on the species richness of the ground vegetation of deciduous forests in northern Germany (Schleswig-Holstein). Forest Ecology and Management 182: $327-$ 338.

HÄTTENSCHWILER, S \& C KÖRNER. 2000. Tree seedling response to in situ $\mathrm{CO}_{2}$ enrichment differ among species and depent on understory light availability. Global Change Biology 6: 213-226.

HELLMOLD, C \& W SCHMIDT. 1989. Energiegehalt und Energiebilanz der Krautschicht eines Kalkbuchenwaldes. Verhandlungen der Gesellschaft für Ökologie 17: 177188.

HIRASAWA, T \& TC HSIAO. 1999. Some characteristics of reduced leaf photosynthesis at midday in maize growing in the field. Field Crops Research. 62: 53-62.

Hoffman, GJ, RAWLINS, LS, GaRber, MJ \& ME CULLEN. 1971. Water relations and growth of cotton as influenced by salinity and relative humidity. Agronomy Journal 63: 822-826.

HOFFMAN, GJ \& JA JOBES. 1978. Growth and water relations of cereal crops as influenced by salinity and relative humidity. Agronomy Journal 70: 765-769. 
HOFLACHER, H \& H BAUER. 1982. Light acclimation in leaves of the juvenile and adult life phases of ivy (Hedera helix). Physiologia Plantarum 56: 177-182.

HOKKANEN, PJ. 2006. Environmental patterns and gradients in the vascular plants and bryophytes of eastern Fennoscandian herb-rich forests. Forest Ecology and Management 229: 73-87.

HOLLISTER, RD \& PJ WeBBER. 2000. Biotic validation of small open-top chambers in tundra ecosystems. Global Change Biology 6: 835-842.

Horvat, I, Glavač, V \& H Ellenberg. 1974. Vegetation Südosteuropas. Gustav Fischer Verlag, Stuttgart.

HSIAO, TC, FRENSCH, J, \& BA ROJAS-LARA. 1998. The pressure-jump technique shows maize leaf growth to be enhanced by increases in turgor only when water status is not too high. Plant, Cell and Environment 21: 33-42.

HUNTER, JH, HSIAO, AI \& GI MCINTYRE. 1985. Some effects of humidity on the growth and development of Cirsium arvense. Botanical Gazette 146: 483-488.

IPCC. 2001. Climate change 2001: Impacts, adaption, and vulnerability. Summary for policymakers. Contributions of working group II. https//:www.iccp.ch.

IPCC. 2007. Climate change 2007: the physical basis. Summary for policymakers. Contributions of working group I to the fourth assessment report of the Intergovernmental Panel of Climate change. https://www.ipcc.ch/SPM2feb07.pdf.

JACKSON, MB, DAVIES, WJ \& MA ELSE. 1995. Pressure flow relationships, xylem solutes and hydraulic conductivity in roots of flooded tomato plants. Annals of Botany 77: 17-24.

Jelaska, SD, ANTONIC, O, BOZIC, M, KRIZAN, J \& V KUSAN. 2006. Response of forest herbs to available understory light measured with hemispherical photographs in silver fir-beech forest in Croatia. Ecological Modelling 194: 209-218.

JIA,WS \& WJ DAVIES. 2007. Modification of leaf apoplastic $\mathrm{pH}$ in relation to stomatal sensitivity to root-sourced abscisic acid signals. Plant Physiology 143: 68-77.

JONASSON, S \& B WIDERBERG. 1988. The resource bilance of Milium effusum with emphasis on environmental resource supply. Oecologia 76: 11-19.

JOVANOVIC, Z. 2004. Effect of $\mathrm{N}$ deficiency on leaf growth and cell wall peroxidase activity in contrasting maize genotypes. Plant and Soil 265: 211-223.

KAPPEN, L, ANDRESEN, G \& R LÖSCH. 1987. In situ observations of stomatal movements. Journal of Experimental Botany 38: 126-142.

KHAIRI, MMA \& AE HALL. 1976. Temperature and humidity effects on net photosynthesis and transpiration of citrus. Physiologia Plantarum 36: 29-34.

KHALIL, AAM \& J GRACE. 1992. Acclimation to drought in Acer pseudoplatanus L. (Sycamore) seedlings. Journal of Experimental Botany 43: 1591-1602. 
KÖlling, C, WALENTOWSKI, H \& H BoRCheRT. 2005. Die Buche in Mitteleuropa. AFZDer Wald 60: 696-701.

KöRner, C, Asshoff, R, Bignucolo, O, HättenschWiler, S, Keel, SG, PelÁEZ-Riedl, S, Pepin,S, Siegwolf, RTW \& G Zotz. 2005. Carbon flux and growth in mature deciduous forest trees exposed to elevated $\mathrm{CO}_{2}$. Science 309: 1360-1362.

KOZLOWSKI, TT \& SG PALLARDY. 1997. Growth control in woody plants. Academic Press, San Diego.

KRAMER, PJ. 1983. Water relations of plants. Academic Press, New York-London.

KRAMER, PJ. 1988. Changing concepts regarding plant water relations. Plant, Cell and Environment 11: 565-568.

KRAMER, PJ \& JS BOYER. 1995. Water relations of plants and soils. Academic Press, San Diego.

KRIEBITZSCH, WU, GRIMmE, K \& J REgel. 1985. Über den $\mathrm{H}_{2} \mathrm{O}$-Gaswechsel von Mercurialis perennis im submontanen Kalkbuchenwald. II. Der Jahresgang der Transpiration in Abhängigkeit von steuernden Parametern. Flora 177: 351-368.

KRIEBITZSCH, WU. 1989. $\mathrm{CO}_{2-}$ und $\mathrm{H}_{2} \mathrm{O}-$ Gaswechsel von verschiedenen Krautschichtpflanzen in einem Kalkbuchenwald nahe Göttingen. Verhandlungen der Gesellschaft für Ökologie 17: 189-202.

KRIZEK, DT, BAILEY, WA \& HH KLUTER. 1971. Effects of relative humidity and type of container on the growth of $\mathrm{F} 1$ hybrid annuals in controlled environments. American Journal of Botany 58: 544-551.

LANGE, OL, LÖSCH, R, SchULZE, ED \& L KAPPEN. 1971. Responses of stomata to changes in humidity. Planta 100: 17-86.

Lebourgeois, F, LÉVy, G, AussenAC, G, Clerc, B \& F Willm. 1998. Influence of soil drying on leaf water potential, photosynthesis, stomatal conductance and growth in two black pine varieties. Annales des Sciences Forestiéres 55: 287-299

LEUSCHNER, C. 2002. Air humidity as an ecological factor for woodland herbs: leaf water status, nutrient uptake, leaf anatomy, and productivity of eight species grown at low or high vpd levels. Flora 197: 262-274.

LEYER, I \& K WESCHE. 2007. Multivariate Statistik in der Ökologie. Springer Verlag, Berlin.

LONDO, G. 1976. Scale for relevés of permanent quadrats. Vegetatio 33: 61-64.

LONDO, G. 1984. The decimal scale for relevés of permanent quadrats. In: KNAPP, R (ed.): Sampling methods and taxon analysis in vegetation science. Handbook of vegetation science. Springer Verlag, Den Haag, pp 45-49.

LÖSCH, R. 2003. Wasserhaushalt der Pflanzen. Quelle \& Meier Verlag, Wiebelsheim. 
MAcFARLANE, C, White, DA, \& MA AdAMS. 2004. The apparent feed-forward response to vapour pressure deficit of stomata in droughted, field-grown Eucalyptus globulus Labill. Plant, Cell and Environment 27: 1268-1280.

MAIER-MAERCKER, U. 1983. The role of peristomal transpiration in the mechanism of stomatal movement. Plant, Cell and Environment 6: 369-380.

MANABE, S \& RT WETHERALD. 1987. Large-scale changes of soil wetness induced by an increase in atmospheric carbon dioxide. Journal of the Atmospheric Science 44: 1211-1235.

MARoco, JP, PereiRA, JS \& MM ChAVES. 1997. Stomatal responses to leaf -to -airvapour pressure deficit in sahelian species. Australian Journal of Plant Physiology 24: 381-387.

MARSCHNER, H. 1995. Mineral nutrition of higher plants. Academic Press, New York.

MARSDEN, BJ, LIEFFERS, VJ \& JJ ZWIAZEK. 1996. The effect of humidity on photosynthesis and water relations of white spruce seedlings during the early establishment phase. Canadian Journal of Forest Research 26: 1015-1021.

MARTENS, SN, BRESHEARS, DD \& CW MEYER. 2000. Spatial distribution of understory light along the grassland/forest continuum: effects of cover, height, and spatial pattern of tree canopies. Ecological Modelling 126: 79-93.

MEIER, IC. 2007. Aboveground and belowground responses of European beech to drought: field studies and experiments. PhD thesis, University of Göttingen.

MONTEITH, JL. 1995. A reinterpretation of stomatal responses to humidity. Plant, Cell and Environment 18: 357-364.

MORRISON-BRAID, LA \& BD WEBSTER. 1978. Relative humidity as a factor in the structure and histochemistry of plants. Advances in Horticultural Science 13: 8-10.

MORTENSEN, LM \& HR GISLERÖD. 2000. Effect of air humidity on growth, keeping quality, water relations, and nutrient content of cut roses. Gartenbauwissenschaft 65: 40-44.

MoRTEnsen, LM, OtTOSEN, CO \& HR GISLERÖD. 2001. Effects of air humidity and K:C ratio on growth, morphology, flowering and keeping quality of pot roses. Scientia Horticulturae 90: 131-141.

MOTT, KA \& DF PARKHURST. 1991. Stomatal responses to humidity in air and helox. Plant, Cell and Environment 14: 509-515.

Munns, R, PAssioura, JB, Guo, J, Chazen, O \& GR Cramer. 2000. Water relations and leaf expansion: importance of time scale. Journal of Experimental Botany 51: 1495-1504.

NASA. 2004. Report: Satellite finds warming "relative" to humidity. https://www.nasa.gov/centers/goddard/news/topstory/2004/0315humidity.html. 
NeJAD, AR \& U MeEteren. 2007. The role of abscisic acid in disturbed stomatal response characteristics of Tradescantia virginiana during growth at high relative air humidity. Journal of Experimental Botany 58: 627-636.

NIEMAN, RH \& LL POULSEN. 1967. Interactive effects of salinity and atmospheric humidity on the growth of bean and cotton plants. Botanical Gazette 128: 69-73.

NightingALE, GT \& JW MitCHELL. 1934. Effects of humidity on metabolism in tomato and apple. Plant Physiology 58: 218-223.

NiInemets, U, Sober, A, Kuli, O, Hartung, W \& JD Tenhunen. 1999. Apparent controls of leaf conductance by soil water availability and via-light-acclimation of foliage structural and physiological properties in a mixed deciduous, temperate forest. International Journal of Plant Science 160: 707-721.

Norby, RJ, hanson, PJ, O’Neill, EG, TSChaplinski, TJ, Weltzin, JF, HANSEN, R, Cheng, WX, Wullschleger, SD, Gunderson, CA, EdWARds, NT \& DW JOHnSON. 2002. Net primary production of a $\mathrm{CO}_{2}$-enriched deciduous forest and the implications for carbon storage. Ecological Applications 12: 1261-1266.

North, M, OAKLey, B, Fiegener, R, GRAY, A \& M BARbour. 2005. Influence of light and soil moisture on Sierran mixed-conifer understory communities. Plant Ecology 177: 13-24.

OISHI, Y. 1991. Productivity-independent initial growth of individual leaves in sunflower (Helianthus annuus L.). Ecological Research 6: 363-369.

O'LEARY, JW \& GW KNECHT. 1971. The effect of relative humidity on growth, yield and water consumption of bean plants. Journal of the American Society for Horticultural Science 96: 263-268.

PACKHAM, JR 1978. Biological flora of the British Isles. Oxalis acetosella L. Ecology 66: 669-693.

PALLARDY, SG \& JL RHOADS. 1993. Morphological adaptations to drought in seedlings of deciduous angiosperms. Canadian Journal of Forest Research 23: 1766-1774.

PASSIOURA, JB \& SC FREY. 1992. Turgor and cell expansion: beyond the Lockhart equation. Australian Journal of Plant Physiology 19: 565-576.

PASSIOURA, JB. 1994. The physical chemistry of the primary cell wall: implications for the control of expansion rate. Journal of Experimental Botany 45: 1675-1682.

PAUSAS, JG \& MP AUSTIN. 2001. Patterns of plant species richness in relation to different environments: an appraisal. Journal of Vegetation Science 12: 153-166.

PEACE, WJH \& PJ GRUBB. 1982. Interaction of light and mineral nutrient supply in the growth of Impatiens parviflora. New Phytologist 90: 127-150.

Peltier, JP \& G MARIgo. 1998. Water stress tolerance of Fraxinus excelsior L. Bulletin of the Ecological Society of America 29: 399-402. 
Peuke, AD, Schraml, C, Hartung, W \& H Rennenberg. 2002. Identification of drought-sensitive beech ecotypes by physiological parameters. New Phytologist 154: 373-387.

Poulson, AD \& H BALSLEV. 1991. Abundance and cover of ground herbs in an Amazonian rain forest. Journal of Vegetation Science 2: 315-322.

POULSON, AD \& IH NIELSON. 1995. How many ferns are there in one hectare of tropical rain forest? American Fern Journal 85: 29-35.

POULSON, AD. 1996. Species richness and density of ground herbs within a 1-ha plot of lowland rainforest in northwest Borneo. Journal of Tropical Ecology 12: 177-190.

PRISCO, JT \& JW O'LEARY. 1973. The effect of humidity and cytokinin on growth and water relations of salt-stressed bean plants. Plant and Soil 39: 263-276.

RANKIN, WT \& EJ TRAMER. 2002. Understory succession and the gap regeneration cycle in a Tsuga canadensis forest. Canadian Journal of Forest Research 32: 16-23.

RAY, JD, GESCH, RW, SINCLAIR, TR \& LH ALLEN. 2002. The effect of vapour pressure deficit on maize transpiration response to a drying soil. Plant and Soil 239: 113-121.

REHDER, H. 1960. Saugkraftmessungen an Stachys sylvatica im frischen und welken Zustand. Berichte der Deutschen Botanischen Gesellschaft 73: 73-82.

Rennenberg, H, Seiler, W, Matyssek, R, Gessler, A \& J KreuzWieser. 2004. Die Buche (Fagus sylvatica) - ein Waldbaum ohne Zukunft im südlichen Mitteleuropa? Allgemeine Forst- und Jagdzeitschrift 175: 210-224.

RESEMANN, A \& K RASCHKE. 1984. Midday depression in stomatal and photosynthesis activity of leaves of Arbutus unedo are caused by large water vapor pressure differences between leaf and air. Plant Physiology 75: 66.

Rijn, CPE, Heersche, I, Berkel, Yem, Nevo, E, Lambers, H \& H PoORTer. 2000. Growth characteristics in Hordeum spontaneum populations from different habitats. New Phytologist 146: 471-481.

ROBERTS, JJ \& JJ ZWIAZEK. 2001. Growth, morphology, and gas exchange in white spruce (Picea glauca) seedlings acclimated to different humidity conditions. Canadian Journal of Forest Research 31: 1038-1045.

ROGERS, RS. 1982. Early spring herb communities in mesophytic forests of the great lake region. Ecology 63: 1050-1063.

ROWELL, DP \& RG JONES. 2006. Causes and uncertainty of future summer drying over Europe. Climate dynamics 27: 281-299.

RUNKLE, JR \& GG WHITNEY. 1987. Vegetation-site relationships in the Lake Katherine State Nature Preserve, Ohio: A northern outlier of the mixed mesophytic forest. Ohio Journal of Science 87: 36-40. 
SALE, PJM. 1970. Growth and flowering of cacao under controlled atmospheric relative humidities. Journal of Horticultural Science 45: 119-132.

SALIM, M. 1989. Effects of salinity and relative humidity on growth and ionic relations of plants. New Phytologist 113: 13-20.

SAXE, H, ElLswOrth, DS \& J HEATH. 1998. Trees and forest function in an enriched $\mathrm{CO}_{2}$ atmosphere. New Phytologist 139: 395-436.

SCHIPKA, F. 2002. Blattwasserzustand und Wasserumsatz von vier Buchenwäldern entlang eines Niederschlagsgradienten in Mitteldeutschland. PhD thesis, University of Göttingen.

SchipkA, F, HeimanN, J \& C LeuschneR. 2005. Regional variation in canopy transpiration of central European beech forests. Oecologia 143: 260-270.

SCHMID, I \& C LEUSCHNER. 1998. Warum fehlt den Gipsbuchenwäldern des Kyffhäusers (Thüringen) eine Krautschicht? Forstwissenschaftliches Centralblatt 117: 277-288.

SCHMIDT, W. 1988. Langjährige Veränderungen der Krautschicht eines Kalkbuchenwaldes (Daueruntersuchungsflächen). Tuexenia 8: 327-338.

SCHMIDT, W, HARTMANN, T, KOTHE-HEINRICH, G \& R SCHULTZ. 1989. Jahresrhytmus und Produktion der Krautschicht in einem Kalkbuchenwald. Verhandlungen der Gesellschaft für Ökologie 17: 145-157.

Scholander, PF, Hammel, HT, Bradstreet, ED \& EA Hemmingsen. 1965. Sap pressure in vascular plants. Science 148: 339-346.

SchönWiese, CD, Bader, S, BöHm, R, Claussen, M, Cubasch, U, FISCHER, H, Gärtner, U, Graßl, H, Rahmstorf, S, Südermann, J, Claussen, M, Kromp-Kolb, H \& H RICHNER. 2003. Klimastatement 2003 der Deutschen Meteorologischen Gesellschaft (DMG), der Österreichischen Gesellschaft für Meteorologie (ÖGM) und der Schweizerischen Gesellschaft für Meteorologie (SGM). http://www.dmgev.de/gesellschaft/aktivitaeten/pdf/klimastatement_2003.

SCHRAML, C \& H RENNENBERG. 2000. Sensitivity of different ecotypes of beech trees (Fagus sylvatica L.) to drought stress. Forstwissenschaftliches Centralblatt 119: 5161.

Schulze, ED, LANGe, OL, Buschbom, U, KaPPEN, L \& M Evenari. 1972. Stomatal responses to changes in humidity in Corylus avellena L. Planta 108: 259-270.

SCHULZE, ED. 1994. The regulation of plant transpiration: interactions of feedforward, feedback and futile cycles. In: Schulze, ED (ed.). Flux Control in Biological Systems: From Enzymes to Populations and Ecosystems. Academic Press, New York, pp. 203-235. 
SHACKEL, KA, MATTHEWS, MA \& JC MORRISON. 1987. Dynamic relation between expansion and cellular turgor in growing grape (Vitis vinifera L.) leaves. Plant Physiology 84: 1166-1171.

SHERIFF, DW. 1984. Epidermal transpiration and stomatal responses to humidity: some hypotheses explored. Plant, Cell and Environment 7: 669-677.

SERPE, MD \& MA MATTHEWS. 2000. Turgor and cell wall yielding in dicot leaf growth in response to changes in relative humidity. Australian Journal of Plant Physiology 27: 1131-1140.

SNIR, N \& PM NEUMANN. 1997. Mineral nutrient supply, cell wall adjustment and the control of leaf growth. Plant, Cell and Environment 20: 239-246.

SPINNLER, D \& C KÖRNER. 2002. Four-year growth dynamics of beech-spruce model ecosystems under $\mathrm{CO}_{2}$ enrichment on two different forest soils. Trees 16: 423-436.

STEER, BT \& J HOCKING. 1983. Leaf and flower production in sunflower (Helianthus annuus L.) as affected by nitrogen supply. Annals of Botany 52: 267-277.

SteVens, CJ, Diese, NB, Mountford, JO \& DJG Gowing. 2004. Impact of nitrogen deposition on the species richness of grasslands. Science 303: 1876-1879.

SVENNING, JC \& F SKOV 2002. Mesoscale distribution of understorey plants in temperate forest (Kalo, Denmark): the importance of environment and dispersal. Plant Ecology 160: 169-185.

SYDES, C \& JP GRIME. 1981. Effects of tree leaf litter on herbaceous vegetation in deciduous woodland. I. Field investigations. II. An experimental investigation. Journal of Ecology 69: 237-248, and 249-262.

TAKAHASHI, K \& T KAMITANI. 2004. Effect of dispersal capacity on forest plant migration at landscape scale. Journal of Ecology 92: 778-785.

TARDIEU, F \& WJ DAVIES. 1992. Stomatal response to ABA is a function of current plant water status. Plant Physiology 98: 540-545.

TARDIEU, F, ZHANG, J \& DJC. GoWING. 1993. A model of stomatal control by both ABA concentration in the xylem sap and leaf water status: test of the model and of alternative mechanisms for droughted and ABA-fed field grown maize. Plant, Cell and Environment 16: 413-420.

TERBORG, O. 1998. Die Kohlenstoffassimilation von Rotbuchen und Traubeneichen in einem Mischbestand in der Lüneburger Heide und deren Bedeutung für die interspezifische Konkurrenz. PhD thesis, University of Göttingen.

TER BRAAK, CJF. 1986. Canonical Correspondence-Analysis - A new eigenvector technique for multivariate direct gradient analysis. Ecology 67: 1167-1179.

TER BRAAK, CJF. 1987. The analysis of vegetation - Environment relationships by Canonical Correspondence-Analysis. Vegetatio 69: 67-77. 
TER BRAAK, CJF \& P SMILAUER. 2002. CANOCO reference manual and CanoDraw for Windows user's guide: software for canonical community ordination (version 4.5). Microcomputer Power, Ithaca, New York.

THOMAS, FM. 2000. Growth and water relations of four deciduous tree species (Fagus sylvatica L., Quercus petraea [Matt.] Liebl., Q. pubescens Willd., Sorbus aria [L.] Cr.) occuring at Central-European tree-line sites on shallow calcareous soils: physiological reaction. Flora 195: 104-115.

THOMPSON, DC, WILKINSON, S, BACON, MA \& WJ DAVIES. 1997. Multiple signals and mechanisms that regulate leaf growth and stomatal behaviour during water deficit. Physiologia Plantarum 100: 303-313.

TiBBItTS, TW \& G BOtTENBERG. 1976. Growth of lettuce under controlled humidity levels. Journal of the American Society for Horticultural Science 101: 70-73.

TIBBITTS, TW 1979. Humidity and plants. BioScience 29: 358-363.

TOGNETTI, R, JOHNSON, JD \& M MICHELOZZI. 1995. The response of European beech (Fagus sylvatica L.) seedlings from two Italian populations to drought and recovery. Trees 9: 348-354.

TROMP, J \& J OELE. 1972. Shoot growth and mineral composition of leaves and fruits of apple as affected by relative air humidity. Physiologia Plantarum 27: 253-258.

TSCHAPLINSKI, TJ, GebRE, GM \& TL SHIRSHAC. 1998. Osmotic potential of several hardwood species as affected by manipulation of throughfall precipitation in an upland oak forest during a dry year. Tree Physiology 18: 291-298.

TUNGATE, KD, ISRAEL, DW, WATSON, DM \& TW RUFTY. 2007. Potential changes in weed competitiveness in an agroecological system with elevated temperatures. Environmental and Experimental Botany 60: 42-49.

TURNER, NC, SCHULZE, ED \& T GoLLAN. 1985. The response of stomata and leaf gas exchange to vapour pressure deficits and soil water content. II. In the mesophytic herbaceous species Helianthus annus. Oecologia 65: 348-355.

TYREE, MT \& PG JARVIS. 1982. Water tissues and cells. In: LANGE, OL, NOBEL, PS, OSMOND, CB \& H ZIEGLER (eds). Encyclopedia of plant physiology. Volume 12 B. Springer Verlag, Berlin, pp. 35-77.

UEA, Climatic Research Unit. 1999. Climate change scenarios for Germany. https://www.cru.uea.u.k./ mikeh/research/wwf.germany.pdf.

Uemura, A, Sishida A, Nakano, T, Terashima, I, Tanabe, H \& Y Matsumoto. 2000. Acclimation of leaf characteristics of Fagus species to previous-year and currentyear solar irradiances. Tree Physiology 20: 945-951.

VAN DE SANDEN, PACM. 1985. Effects of air humidity on growth and water exchange of cucumber seedlings. Preliminary report. Acta Horticulturae 174: 259-264. 
Vos, J, VAN DER PutTen, PEL \& CJ BIRCH. 2005. Effect of nitrogen supply on leaf appearance, leaf growth, leaf nitrogen economy and photosynthetic capacity in maize (Zea mays L.). Field Crop Research 93: 64-73.

WALLER, JM. 1976: The influence of climate on the incidence of some diseases of tropical crops. Review of Plant Pathology 55: 185-194.

WEBB, LJ. 1968. Environmental relationships of the structural types of Australian rainforest vegetation. Ecology 49: 296-311.

WENT, FW. 1957. The experimental control of plant growth. Ronald Press, New York.

WERNEYER, B. 2003. Der Einfluss von Luft- und Bodenfeuchte auf das Wachstum dreier mitteleuropäischer Laubbaumarten. Unpublished diploma thesis, University of Kassel.

WESTGATE, ME \& JS BOYER. 1985. Osmotic adjustment and the inhibition of leaf, root, stem and silk growth at low water potentials in maize. Planta 164: 540-549.

WETHERALD, RT \& S MANABE. 1995. The mechanisms of summer dryness induced by greenhouse warming. Journal of Climate 8: 3096-3108.

WHITMORE, TC. 1973. Plate tectonics and some aspects of Pacific plant geography. New Phytologist 72: 1185-1190.

WHITMORE, TC. 1984. The Tropical Rain Forests of the Far East. Oxford University Press, Oxford.

WHITTAKER, RH. 1956. Vegetation of the Great Smoky Mountains. Ecological Monographs 26: 1-80.

WIESER, G \& WM HAVRANEK. 1996. Evaluation of ozone impact on mature spruce and larch in the field. Journal of Plant Physiology 148: 189-194.

WILLETT, KM. 2007. Creation and analysis of HadCRUH: a new global surface humidity dataset. PhD thesis, University of East Anglia Norwich.

WINNEBERGER, JH. 1958. Transpiration as a requirement for growth of land plants. Physiologia Plantarum 11: 56-61.

WITTICH, B. 2007. Einfluss von experimentell manipulierter Luftfeuchte und Strahlung auf Wachstum und Morphologie von Waldbodenpflanzen. Unpublished diploma thesis, University of Göttingen.

WOODWORD, RG \& JE BEGG. 1976. The effect of atmospheric humidity on the yield and quality of soya bean. Australian Journal of Agricultural Research 27: 501-508.

ZHANG, J, SCHURR, U \& WJ DAVIES. 1987. Control of stomatal behaviour by abscisic acid which apparently originates in the roots. Journal of Experimental Botany 38: 1174-1181. 
ZHANG, J \& WJ DAVIES. 1990a. Changes in the concentration of ABA in xylem sap as a function of changing soil water status can account for changes in leaf conductance and growth. Plant, Cell and Environment 13: 277-285.

ZHANG, J \& WJ DAVIES. 1990b. Does ABA in the xylem control the rate of leaf growth in soil-dried maize and sunflower plants? Journal of Experimental Botany 41: 11251132 


\section{Herzlich bedanken möchte ich mich bei}

Christoph Leuschner für die ständige Hilfsbereitschaft während dieser Arbeit und für die motivierenden Worte, gerade in der Anfangsphase.

Michael Kessler für die Übernahme des Korreferats.

Sandra Korn und Ina Meier für die ständige Hilfsbereitschaft, die unzähligen lustigen Momente und die vielen netten Abende.

Christina Munderloh und Catharina Meinen für die langjährige Freundschaft und die vielen unterstützenden Worte.

Paul Holden und Holger Buschmann für ihre hilfreichen Verbesserungsvorschläge.

Heinz Coners für die Hilfe bei jeglichen technischen Problemen und für viele hilfreiche Ideen.

Der gesamten Abteilung für das nette Arbeitsklima und die vielen gemeinsamen Grillund Kneipenabende.

Den Mitarbeitern der Pflanzenökologie für die Hilfe im Feld und für die Analysen im Labor.

Regina Helbig für die Hilfe bei der Anzucht der Pflanzen und bei etlichen Einsätzen im Wald.

Der Deutschen Bundesstiftung Umwelt und Frau Schlegel-Starmann, nicht nur für die Förderung dieser Arbeit, sondern auch für die vielen angenehmen Seminare und die neu gefundenen Freundschaften.

Meinen Eltern, die mir mein Studium erst ermöglichten und die immer an mich geglaubt haben.

Meinem Freund, Juan Manuel Mantilla der immer für mich da war und nie an mir gezweifelt hat. 


\section{Curriculum vitae}

Persönliche Daten

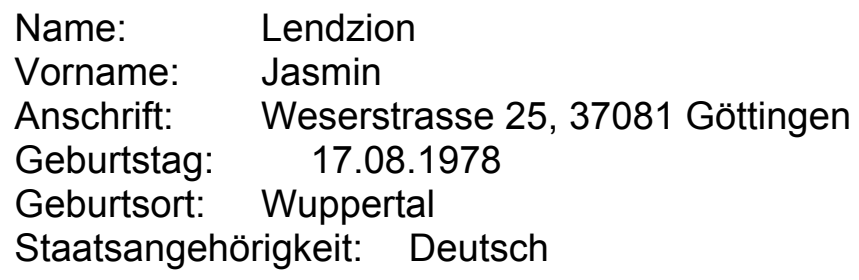

Schulischer Werdegang

10.06.1998

1989-1998

Allgemeine Hochschulreife

1985-1989

Gesamtschule des Ennepe-Ruhr-Kreises

Grundschule Hasslinghausen

Akademischer Werdegang

Seit $2003 \quad$ Promotion in der Abteilung Ökologie und Ökosystemforschung, Albrecht-von-Haller Institut für Pflanzenwissenschaften, Georg-

24.11.2003

August-Universität Göttingen

Diplom

Thema der Diplomarbeit: Krautflora dreier Waldtypen im Übergang der Tropen zu den Subtropen in Zentralbolivien

1998-2003 Studium der Biologie an der Georg -August-Universität Göttingen

Praktika und berufliche Erfahrung

2003-2005 Betreuung zahlreicher Veranstaltungen der Biologie als wissenschaftliche Hilfskraft am Albrecht-von-Haller Insitut für Pflanzenwissenschaften, Georg-August-Universität Göttingen

2002 Betreuung einer Veranstaltung der Biologie als studentische Hilfskraft am Albrecht-von-Haller Insitut für Pflanzenwissenschaften, Georg-August-Universität Göttingen

2002 Botanikpraktikum am "Herbario Nacional de Bolivia", La Paz, Bolivien

2001 Studentische Hilfskraft im Projekt "Hypsometrischer Wandel naturnaher Bergregenwaldökosysteme in den Yungas Boliviens", Yungas, Bolivien

Göttingen, den 18.09.2007 